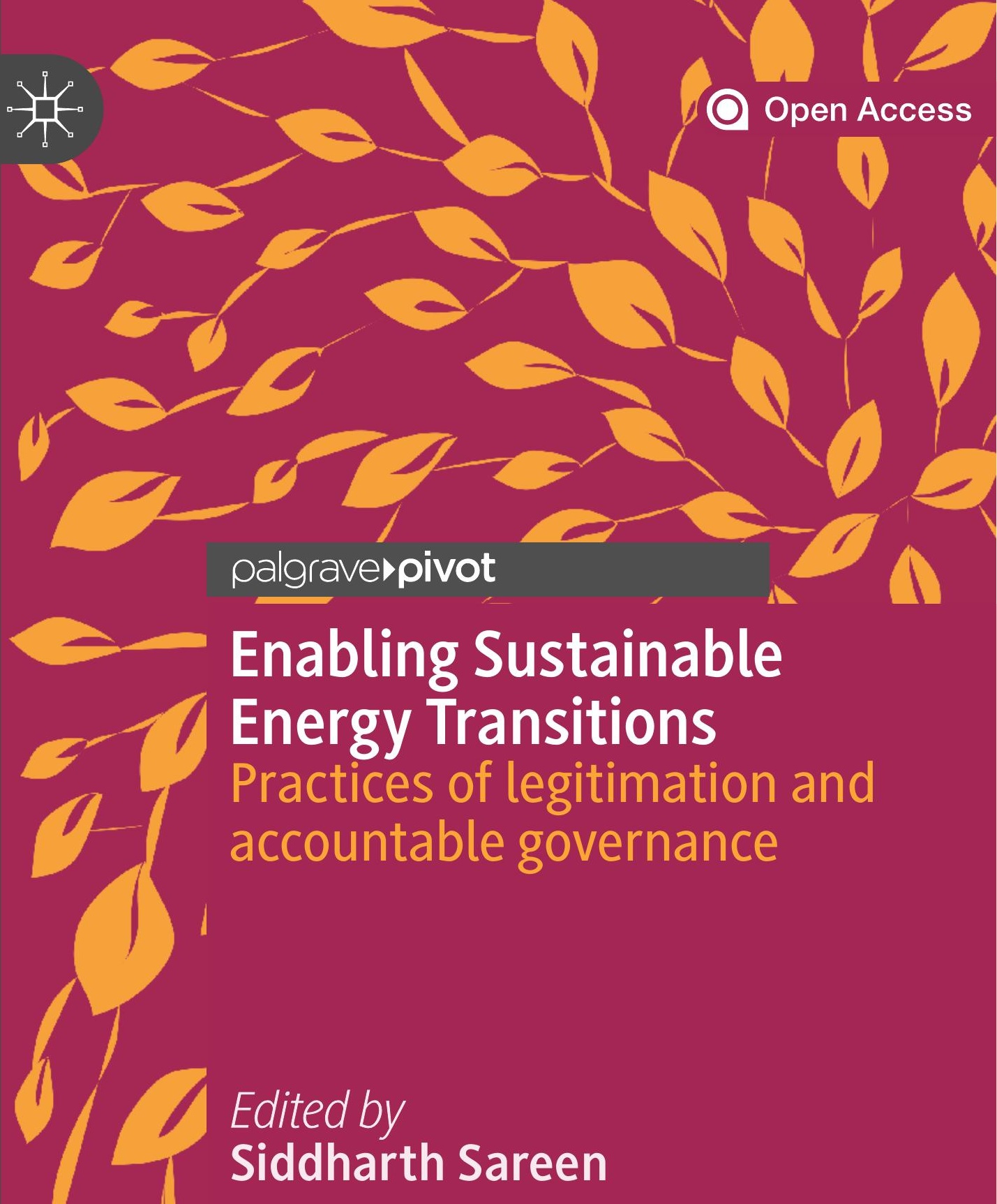




\section{Enabling Sustainable Energy Transitions}

"If we are to close the gap between words and deeds on decarbonisation, emission reductions need to go much faster and further than at present. Enabling Sustainable Energy Transitions steps directly into this gap, arguing that inadequate action relative to the scale of the problem constitutes a crisis of accountability. This crisis is sustained, the authors propose, by four 'practices of legitimation' through which states, firms and other key actors are effectively insulated from the political and economic consequences of inaction. In tune with the recent pivot in energy research from innovation to incumbency, and the post-Paris challenge of rapidly dismantling fossil energy regimes, this compact book argues that ideas about accountability and legitimation-drawn from work on environmental governance-can open up new analytical perspectives on what is holding back effective energy system transformation. With bite-size chapters and illustrative cases that draw on the work of five expert witnesses, this is a novel intervention into debates over the politics of energy transition."

—Gavin Bridge, Professor, Department of Geography, Durbam University

"In this comprehensive and much-needed book, Dr. Siddharth Sareen with colleagues provides a compelling analysis of the sustainable energy transition and the role of legitimation practices and accountability therein. The book theorizes and advances the research frontier on legitimation practices and accountability with a carefully crafted analysis bridging scholarly fields of environmental governance, political economy, energy research and democratic theory. Enabling Sustainable Energy Transition presents a novel empirical analysis of the politics of energy transition across the world through rich case studies of countries such as Portugal, Germany, Norway, USA as well as cities such as Berlin. This book is a must-read for all students and scholars interested in shaping more legitimate, democratic and accountable energy transition from the local to global context."

-Karin Bäckstrand, Professor, Department of Political Science, Stockholm University 
Siddharth Sareen

Editor

\section{Enabling Sustainable Energy Transitions}

Practices of legitimation and accountable governance 


\section{Editor}

Siddharth Sareen

Department of Geography

Centre for Climate and Energy Transformation

University of Bergen, Bergen, Norway

ISBN 978-3-030-26890-9

ISBN 978-3-030-26891-6 (eBook)

https://doi.org/10.1007/978-3-030-26891-6

(C) The Editor(s) (if applicable) and The Author(s), under exclusive licence to Springer

Nature Switzerland AG 2020 This book is an open access publication

Open Access This book is licensed under the terms of the Creative Commons Attribution 4.0 International License (http://creativecommons.org/licenses/by/4.0/), which permits use, sharing, adaptation, distribution and reproduction in any medium or format, as long as you give appropriate credit to the original author(s) and the source, provide a link to the Creative Commons licence and indicate if changes were made.

The images or other third party material in this book are included in the book's Creative Commons licence, unless indicated otherwise in a credit line to the material. If material is not included in the book's Creative Commons licence and your intended use is not permitted by statutory regulation or exceeds the permitted use, you will need to obtain permission directly from the copyright holder.

The use of general descriptive names, registered names, trademarks, service marks, etc. in this publication does not imply, even in the absence of a specific statement, that such names are exempt from the relevant protective laws and regulations and therefore free for general use. The publisher, the authors and the editors are safe to assume that the advice and information in this book are believed to be true and accurate at the date of publication. Neither the publisher nor the authors or the editors give a warranty, express or implied, with respect to the material contained herein or for any errors or omissions that may have been made. The publisher remains neutral with regard to jurisdictional claims in published maps and institutional affiliations.

This Palgrave Pivot imprint is published by the registered company Springer Nature Switzerland AG.

The registered company address is: Gewerbestrasse 11, 6330 Cham, Switzerland 


\section{Prologue}

When I was 11, I lived in the river plains of northern India, a region poorer than sub-Saharan Africa (Alkire and Santos 2014). It was before the turn of the millennium, and while the mercury routinely went past $45^{\circ} \mathrm{C}$, my household struggled to cope with frequent power cuts totalling a dozen hours a day. We had the relative luxury of a diesel generator and an inverter, cooked using gas cylinders and a parabolic solar cooker, used electric water heaters, and the nightwatchman burnt charcoal to stay warm on winter nights and cooked his morning meals on a woodstove.

When I was 21, I lived on an elite university campus where the government ensured round-the-clock power supply so the lights never went out. Months before Copenhagen hosted the United Nations Framework Convention on Climate Change (UNFCCC) Conference of Parties (CoP) 15, I was an invited student delegate at a global sustainable development summit. Midway through, during a plenary session with the then-head of the Intergovernmental Panel on Climate Change (IPCC) and a leading British Broadcasting Corporation news anchor, I posed a question in the limelight. In two days of discussions on how to address the climate change challenge, why had nobody discussed the role of the United States of America (Christoff 2010), since our prospects looked bleak without its geopolitical backing and political economic will?

Now 31 years old, I live in Norway, one of the richest countries in the world with a fortune built on oil, with hydropower its predominant domestic energy source. My home runs almost entirely on electricity, from heating to cooking to hot water. Our transport systems are increasingly electric, except air travel which continues to be carbon emissions intensive 
and popular. During the CoP 24 in Katowice, the centre of coal in Europe, someone half my age spoke truth to power. Greta Thunberg said that our political representatives have failed us and that we must act now to address the climate crisis for today's youth and the vulnerable to have livable futures.

Those three decadal conjunctures of material configuration, institutional context and relative privilege reveal a great deal about the spatiotemporally contingent nature of how we experience the deeply entangled climate and energy crises. My concern with these contemporary crises has continued and increased in my transition from childhood to mid-career researcher; and so has the associated urgency. We live in a time of many crises-local, national and global; short-, medium- and long-term; social, environmental and economic - and the heart of each one is political. This book concerns the greatest crisis of our times, which spans generations. It is about addressing the drivers and impacts of climate change, which means rapidly decarbonising our energy systems, and deeply changing whom they benefit (Bickerstaff et al. 2013). This is a mammoth task with competing stakes, too vital to be left to privileged sets of decision-makers who have already failed to safeguard and secure public interest for decades, and much too big for a modest book. Rather, its envisaged contribution is to show how to make this crisis visible for what it truly is-a crisis of accountability-opening up space to discuss and establish anew (Dowdle 2017) the terms for more accountable governance to enable sustainable energy transitions. For the purpose of this book, the term 'sustainable energy transitions' signifies changes to our energy systems that enhance both decarbonisation and social equity.

I undertake this ambitious task in good company. That of countless excellent scientists past and present who have furnished a rigorous basis in knowledge and whose work I draw on-we already know much of what we need to know for sustainable energy transitions. Your company as a reader, as someone interested in understanding and addressing this crisis- this book is accessible to laypersons and experts, and aspires to be an engaging, inspiring read. The company of environmental governance researchers who have spent a great deal of their eminent careers examining various aspects of energy transitions and kindred subjects, which span many sectors and domains. And finally of the many people these colleagues and I have interacted with in the field-for our research is empirically informed-who help keep our work grounded and relevant. This 
combination is key in making an argument that at its crux concerns practices of legitimation.

What is legitimation, why does it feature practices, and what does it have to do with a crisis of accountability? Notably, an accountability crisis is distinct from the Habermasian notion of a legitimation crisis, which refers to a confidence deficit in leadership, institutions or administrative functions among the subjects of the state in an era of late capitalism. To wit:

The state can avoid legitimation problems to the extent that it can manage to make the administrative system independent of the formation of legitimating will. To that end, it can, say, separate expressive symbols (which create a universal willingness to follow) from the instrumental functions of administration.... The scope for manipulation, however, is narrowly delimited, for the cultural system remains peculiarly resistant to administrative control. There is no administrative creation of meaning, there is at best an ideological erosion of cultural values. The acquisition of legitimation is selfdestructive as soon as the mode of acquisition is exposed. Thus, there is a systematic limit for attempts at making up for legitimation deficits by means of well aimed manipulation. This limit is the structural dissimilarity between areas of administrative action and cultural tradition. (Habermas 1973: 657)

This book adopts a similar premise but a different point of entry. Taking forward an approach developed by Kraft and Wolf (2018), legitimation is a relationally produced artefact that can be empirically scrutinised to characterise accountability. Where an accountability crisis occurs, it need not manifest as breakdown (a legitimation crisis) but can be upheld through practices of legitimation even as things run aground. In this sense, we have been in an accountability crisis for centuries, and in the case of many actors knowingly so for decades, extracting and consuming resources with deeply inequitable distributions and emitting carbon (and other greenhouse gases - this book uses 'decarbonisation' as shorthand) that far exceed sustainable limits. Legitimation refers to the process through which an act (by its doer) is recognised as valid (by its authoriser and its public) in relation to societal norms. This process involves a set of distinct practices. Practices of legitimation are social relations premised on accountability and constitutive of it. Sectoral changes manifest in and through them. Thus, practices of legitimation embody the very means by which an act becomes legitimate and normalised (Luckmann 1987). They are necessarily also the relational sites where such normalisation can be laid bare and challenged. Such informed exposure represents Habermas' systematic 
limit, beyond which manipulation cannot make up for legitimation deficit. In the contemporary context of increasing right-wing authoritarian tendencies and climate scepticism, informed exposure is not straight-forward but tautly contested and requires rigorous evidence.

Questioning a practice of legitimation is a way of bringing an act to account, by holding accountable its doer, its authoriser, or both, to the broader publics affected by their actions. There is no singular public or normative standard (West and Davis 2011), as scholarly theorisations of institutional orders and orders of worth remind us (Boltanski and Thévenot 2006; Patriotta et al. 2011). Yet environmental governance and political ecology research have made inroads into questions of power and representation, and a normative goal such as sustainability has secured broad, albeit not uncontested, social legitimacy in terms of the desirability of decarbonisation that also enhances social equity. Nation states-and, in a polycentric world, trans-local networks of multi-scalar actors-have made strong verbal, political, policy and in some cases even legal commitments to achieving substantive transitions to sustainability. Nonetheless, global carbon emissions continue to increase, and human-made disasters are becoming normed into the anthropocene, with exacerbated threats of wildfires and floods causing widespread loss of human life, infrastructure and biodiversity. With a crisis of accountability of this magnitude-where societal foundations such as the energy system must open up to questioning-being increasingly recognised with public demands to address it, practices of legitimation occur wherever action is observable, whether to resolve the crisis or to profit by prolonging it. These practices are our windows to institutional change in the making (Dansou and Langley 2012), and our points of entry to not only examine and understand but also to inform and intervene.

To me, this is both a professional and personal quest: $45^{\circ} \mathrm{C}$ summer days with no electricity for half the day is not just a memory from my childhood; it embodies the reality of the current lives of mind-bogglingly many people. We continue to shy away from some of the most pressing and difficult questions when it comes to acting on climate change: how is it that the powerful continue to act in unacceptable, unabashedly consumerist ways without being held to account, while highly vulnerable groups bear the brunt of the impact with precious little say?

We cannot change everything at once; what is in place keeps the world as we know it in play and nourishes very powerful parts of it. But we must 
pick it apart (through informed analysis) to improve upon it (for constructive change); for if we let things continue as they are, we are condemning billions of people and many other organisms besides to the suffering entailed by runaway climate change (Wallace-Wells 2019).

The energy system is not only a huge contributor to climate change, it is also humankind's greatest accomplishment and most devastating horror all rolled into one. Nothing has enabled greater human achievement and progress; nothing has led to more pronounced inequity and irreversible destruction. Consider the sophisticated command over resources to supply the energy needs of billions on the one hand, and the ruination of entire ways of life in extracting resources and setting up supply chains to do so on the other hand. Or a transatlantic jetplane for a millionaire versus a habitation flooded by damming respectively; or a neon-lit city versus a fracking landscape- the list is endless.

This book, then, seeks to provide a pick-axe of sorts. It offers an analytical approach to cut into practices of legitimation and examine how things are propped up, what must yield, and who is pushing for the sorts of changes that will enable sustainable energy transitions. A scientific way to evidence common-sense (Jovchelovitch 2008), get an empirical handle on the opportunities to decarbonise and render equitable our changing energy systems, and provide a basis for the public to put its feet down against the acts and actors who would rather watch the world burn, literally, than lose the untenable privileges of a small but powerful group of elites.

Part I of the book frames what research has already conclusively shown about feasible and necessary energy transitions, and puts forward an analytical typology of practices of legitimation to make headway towards sustainability in any given instance of energy transition. Part II explains the invitation to five colleagues to reflect on their varied cases related to energy transitions in terms of accountability and legitimation, and comprises their responses to this invitation in the form of five case chapters. Part III synthesises our reflections on how to take forward energy transitions analysis along such lines. We thus aim to pave a pathway for enmeshed empirical and theoretical studies of practices of legitimation towards accountable governance that can enable sustainable energy transitions. 


\section{REFERENCES}

Alkire, S., \& Santos, M. E. (2014). Measuring acute poverty in the developing world: Robustness and scope of the multidimensional poverty index. World Development, 59, 251-274.

Bickerstaff, K., Walker, G., \& Bulkeley, H. (Eds.). (2013). Energy justice in a changing climate: Social equity and low-carbon energy. Zed Books Ltd.

Boltanski, L., \& Thévenot, L. (2006). On justification: Economies of worth. Princeton, NJ: Princeton University Press.

Christoff, P. (2010). Cold climate in Copenhagen: China and the United States at COP15. Environmental Politics, 19(4), 637-656.

Dansou, K., \& Langley, A. (2012). Institutional work and the notion of test. Management, 15(5), 503-527.

Dowdle, M. W. (2017). Public accountability: Conceptual, historical and epistemic mappings. In P. Drahos (Ed.), Regulatory theory: Foundations and applications (pp. 197-215). Canberra: Australian University Press.

Habermas, J. (1973). What does a crisis mean today? Legitimation problems in late capitalism. Social Research, 40, 643-667.

Jovchelovitch, S. (2008). The rehabilitation of common sense: Social representations, science and cognitive polyphasia. Journal for the Theory of Social Behaviour, 38(4), 431-448.

Kraft, B., \& Wolf, S. (2018). Through the lens of accountability: Analyzing legitimacy in environmental governance. Organization o Environment, 31(1), 70-92.

Luckmann, T. (1987). Comments on legitimation. Current Sociology, 35(2), 109-117.

Patriotta, G., Gond, J. P., \& Schultz, F. (2011). Maintaining legitimacy: Controversies, orders of worth, and public justifications. Journal of Management Studies, 48(8), 1804-1836.

Wallace-Wells, D. (2019). The uninhabitable earth: Life after Warming. Tim Duggan Books.

West, K., \& Davis, P. (2011). What is the public value of government action? Towards a (new) pragmatic approach to values questions in public endeavours. Public Administration, 89(2), 226-241. 


\section{Contents}

Part I Introduction

1 Reframing Energy Transitions as Resolving Accountability Crises

Siddharth Sareen

2 A Typology of Practices of Legitimation to Categorise Accountability Relations Siddharth Sareen

3 Five Easy Pieces: Legitimation at Work in Cases Related to Energy Transitions

Siddharth Sareen

4 Historicising Accountability: Berlin's Energy Transitions Timothy Moss 
5 A Few Reflections on Accountability

Christian Lund

6 Do Climate Targets Matter? The Accountability of Target-setting in Urban Climate and Energy Policy Håvard Haarstad

7 Governance and Legitimation in the Transition to Nordic Electric Mobility

Benjamin Sovacool

8 Accountability and the Regulation of Legitimacy:

Biodiversity Conservation and Energy Extraction in the American West

Steven Wolf

Part III Conclusion

9 Practices of Legitimation and Accountability Crises in a Range of Energy Transitions

Siddharth Sareen

10 Conclusion: Legitimation and Accountability in Energy Transitions Research

Siddharth Sareen, Timothy Moss, Christian Lund, Håvard Haarstad, Benjamin Sovacool, and Steven Wolf

Appendix A

Appendix B

Index 


\section{Notes on Contributors}

Håvard Haarstad is Professor of Human Geography at the University of Bergen. He is interested in sustainability, climate change and energy in relation to cities. He focuses on how mobile ideas and policies shape the way cities become sustainable, and on social theory about climate and energy transformation.

Christian Lund is Professor of Development, Resource Management and Governance at the University of Copenhagen. He has a keen interest in discussions about the state and politico-legal institutions, and the ways in which social action produces public authority. His research focuses on property, local politics and state formation.

Timothy Moss is a senior researcher at the Integrative Research Institute on Transformations of Human-Environment Systems, Humboldt University of Berlin. With a history and political science background, his research revolves around the processes of institutional change relating to public goods and their spatiality in general, and urban infrastructure systems in particular.

Siddharth Sareen is a postdoctoral researcher at the Centre for Climate and Energy Transformation and the Department of Geography at the University of Bergen. He has an interdisciplinary background in the environmental social sciences, and works on the governance of energy transitions and questions of resource access and authority.

Benjamin Sovacool is Professor of Energy Policy at the University of Sussex. He works on energy policy, energy security, and climate change 
mitigation and adaptation. His research focuses on renewable energy and energy efficiency, large-scale energy infrastructure politics, improving public policy for energy access, and building adaptive capacity.

Steven Wolf is Associate Professor of Environmental Social Science at Cornell University. His research on environmental governance focuses on efforts to secure public goods from private landscapes. His training and approach engage sociology and economics, with an interest in socioecological dynamics in both industrialised and rapidly industrialising societies. 


\section{List of Figures}

Fig. 4.1 Map showing size of Berlin prior to 1920 (marked core area) and territory of municipalised power utilities by 1925 (vertically striped area). (Source: Bruno Thierbach, 1925, Die gegenwärtige Versorgung der Stadt Berlin und der Provinz Brandenburg mit elektrischer Arbeit. Elektrotechnische Zeitschrift, 46(39), 1465)

Fig. 4.2 Protest camp against the planned power plant in Spandau Forest, 1976. (Source: Landesarchiv Berlin, F Rep 290, No. 0194-662)

Fig. 4.3 Campaign poster of the Berlin Energy Roundtable for the 2013 referendum, reading 'Our municipal utility, our power grid, our Berlin'. (Source: http://www.berliner-energietisch. net/materialien)

Fig. 7.1 Diffusion of electric vehicles in the five Nordic countries, 2009 to 2017. (Source: Kester et al. 2018)

Fig. 8.1 Co-evolution of nature and society mediated by accountability mechanisms and legitimacy tests

Fig. B1.1 Setting up the exhibition at Bergen Public Library

Fig. B1.2 The 'Idea box for energy transitions' exhibition. (Photo credit: Hordaland Kunstsenter)

Fig. B1.3 The idea box as part of the exhibition at Bergen Public Library. (Photo credit: Hordaland Kunstsenter)

Fig. B1.4 Workshop participants browse the idea box for energy transitions exhibition 
Fig. B1.5 Bridging the exhibitions at Bergen Public Library and Hordaland Kunstsenter

Fig. B1.6 'Rhythmic energy mixes: Days and years with Dr. Siddharth Sareen' by Margrethe Brekke

Fig. B1.7 Margrethe Brekke's 'Potential exceeds the demand' exhibition at Hordaland Kunstsenter

Fig. B1.8 Margrethe Brekke reflects on her art exhibition while giving a guided tour

Fig. B1.9 The forces behind the artistic events

Fig. B1.10 'Imaginaries of energy transition: Public, artistic and academic' with Margrethe Brekke and Benjamin Sovacool

Fig. B1.11 Exchanges between the arts, academia and the public

Fig. B1.12 Theatrical performances by International School of Bergen students directed by Annie Sareen

Fig. B1.13 The accountability analysis workshop at Bergen Public Library

Fig. B1.14 Timothy Moss gives a keynote talk at the workshop on accountability analysis

Fig. B1.15 Christian Lund and Håvard Haarstad during a workshop keynote session

Fig. B1.16 Discussions among the workshop participants continued over dinner

Fig. B1.17 Closing workshop dinner with keynote speakers 158

Fig. B1.18 Starting festivities on the national day of Norway 159

Fig. B1.19 A traditional torchlight procession through Bergen 160

Fig. B1.20 The annual fireworks on 17 May in Bergen 


\section{List OF TABLES}

Table 7.1 An overview of the electricity and mobility regimes in the Nordic region

Table 7.2 Positive and negative synergies with electric mobility and sustainability

Table 7.3 Policy mechanisms for more sustainable and just Nordic electric mobility

Table 10.1 Practices of legitimation with indicative dimensions for five wide-ranging cases 


\section{Introduction}




\title{
Reframing Energy Transitions as Resolving Accountability Crises
}

\author{
Siddharth Sareen
}

\begin{abstract}
Using the concrete case of solar energy uptake in Portugal, Chap. 1 illustrates how energy transitions can be regarded as attempts to resolve crises of accountability. While Portugal is among the countries that lead globally on energy transitions, close attention to its apparently promising solar energy prospects reveals a paradox: progress has been slow and modest. Yet, there seems to be a major change on the horizon, and a potentially powerful explanation for these dynamics is premised on relations of accountability amongst stakeholders in Portugal's energy sector. Having argued that such a reframing of energy transitions has explanatory power, the chapter deconstructs accountability as an underlying relationship which is produced by various practices that manifest as legitimation. It argues for an analytical typology of legitimation.
\end{abstract}

Keywords Accountability crisis • Legitimation • Energy transitions • Solar • Portugal

\footnotetext{
S. Sareen $(\bowtie)$

Department of Geography, Centre for Climate and Energy Transformation, University of Bergen, Bergen, Norway e-mail: Siddharth.Sareen@uib.no

(C) The Author(s) 2020

S. Sareen (ed.), Enabling Sustainable Energy Transitions, https://doi.org/10.1007/978-3-030-26891-6_1
} 


\subsection{Sustainable Energy Transition as a Response TO An Accountability Crisis}

In terms of national performance on energy transitions, few countries are more remarkable than Portugal. Already among Europe's leaders on renewable energy, its carbon mitigation from 2017 to 2018 was 9 per cent, the highest rate on the continent and over thrice the European average. ${ }^{1}$ This small and relatively isolated country bordering Spain in the western part of the Iberian Peninsula with ten million residents has, thus, exceeded expectations.

Solar energy uptake in Portugal poses a surprising paradox: despite Portugal's leadership on renewable energy in the progressive energy policy context of Europe, with strong wind and hydro power assets and some of the continent's best solar irradiation conditions for cost-competitive lowcarbon generation (Krajačić et al. 2011), till 2019, it has only installed modest solar energy capacity. Combined with no fossil fuel assets to speak of as an importer of coal, oil and natural gas, it would seem a no-brainer for Portugal to capitalise on remarkable global decreases in the price of solar energy infrastructure and promote a rapid solar uptake to move towards a largely decarbonised energy sector (Fortes et al. 2019).

Empirical research and mainstream media reports have unearthed numerous barriers for solar energy uptake, such as the lack of policy visibility, a restrictive regulatory framework, limited licences, grid constraints and limited credit access. These explain the relatively modest increases in installed solar capacity and surface some narratives of frustration. Emerging studies and reports, most notably Portugal's National Energy and Climate Plan, convey a sense that eventually things will work themselves out and solar projects will increasingly go ahead (Coelho et al. 2017), especially at utility scale, meaning in the multi-million dollar range. There has been insufficient transmission grid capacity for the national energy regulator to allow very many new solar installation in the locations with highest irradiation down south; till 2019, guidelines on how existing grid capacity should be allocated were unclear; and when transparent guidelines did emerge it was into a context with a little informed public debate on such crucial priorities regarding the country's energy future and low-carbon transition

\footnotetext{
${ }^{1}$ Eurostat news release 81/2019, dated 08.05.2019. Accessed 24.05.2019 at https:// ec.europa.eu/eurostat/documents/2995521/9779945/8-08052019-AP-EN. pdf/9594d125-9l63-446c-b650-b2b00c531d2b.
} 
(Sareen and Haarstad 2018; Vasconcelos 2018). Then, a scandal in another ministry ahead of a national election year led to a cabinet reshuffle. The emergence of a new ministry with a new minister of environment and energy transition, as well as European Commission mandates, prompted the launch of a national climate and energy policy and a national decarbonisation roadmap 2050 (Sareen in review). At the time of writing, Portugal had scheduled solar capacity auctions for over 2 Giga Watts during 2019, and adopted a newly ambitious target that includes a tenfold increase in solar energy capacity within a decade.

To those well versed with energy sector dynamics, 'incumbency' and 'path dependence' (Sovacool 2016; Lockwood et al. 2017) are terms that will suggest themselves easily given the particular trajectory up to 2019, and potentially also disruption to describe evolving circumstances (Winskel 2018). Portugal has a history of a veritable monopoly in its energy sector by Energias de Portugal (EDP). Like many other countries, it moved from electricity being a largely publicly held sector to increased privatisation during the past quarter century. EDP remains an outsize vertically integrated player in this sector but is multinational and privately held. A great deal of control over its own energy infrastructure has shifted out of Portuguese hands of late with sustained interest by Chinese investors (Pareja-Alcaraz 2017), not least during Portugal's battle with economic recession and European Union pressure during 2009-2015.

The sector has changed, but the memory of a particular mode of functioning maintains a stronghold in the mind of decision-makers (Delicado et al. 2016). EDP is a major player in renewables-hydro and wind power in Portugal-but its solar energy assets are held abroad rather than in Portugal. Here, it has leveraged its presence in fossil fuel generation and protected investments in thermal plants in the hope that these will turn over a tidy profit for years hence. Timing is thus crucial in terms of who stands to benefit from Portugal's solar energy transition (Sareen et al. 2018). It is perhaps not all that surprising that so far there has been no particular rush to implement a dramatic increase in solar uptake. After all, things are running smoothly, Portugal is meeting European targets on renewable energy, and a cash-strapped economy has competing priorities, so why mess with a good enough energy sector? And yet, with the announcement of solar auctions for summer 2019 by the government of Portugal signalling a clear pathway, EDP publicly stated its interest in participating and submitting bids. 
It is crucial to unpack this tension between a 'good enough' status quo that has lingered for years and the promise of upcoming large-scale dynamism in order to understand the changing energy sector and the adaptive behaviour of various stakeholders. What is the underlying normative commitment-what suffices and why, and by contrast, what catalyses change and when? Does Portugal exemplify a sustainable energy transition underway? Or does it normalise something well short of reasonable action, simply because legal and discursive space permit it without sufficiently rigorous tests (Dansou and Langley 2012)? These questions approach the nub of the argument presented below: in the Portuguese case of gradual solar uptake as in most current energy transitions, we know what the problem is, we know a good deal about how to solve it and yet do little about it, and this disjuncture is a crisis of accountability (Mason 2008).

From the normative standpoint of decarbonisation, Portugal should be putting all the weight it can behind rapid, even exponential, solar uptake, dealing with its disruptive effects head-on in order to decarbonise quickly. Adding an equity dimension, it should be encouraging a vibrant public debate about how to ensure that such a sectoral transition enhances social equity or at least does not work against it. Till recently, these discussions barely existed, and as they emerge, they play out amongst 'experts' and those who often represent specific stakes in the sector (cf. West and Davis 2011). There has been at best a fringe discussion on various public stakes in energy transitions and the necessity for a solar energy transition to happen rapidly and to produce public benefits (Delicado et al. 2014; Sareen and Haarstad 2018)-both in terms of enhancing current social equity and by way of securing improved intergenerational equity through climate change mitigation.

What does solar energy have to do with social equity? Within Europe, Portugal has one of the highest national rates of energy poverty, a condition whereby people cannot secure adequate home energy services. Some 800,000 of the country's ten million residents avail subsidised electricity tariffs. Yet, the current energy sector regime does not incentivise 'prosuming', or selling solar energy back to the grid. It mainly promotes selfconsumption (Camilo et al. 2017), which does not appeal much to small households considering installing rooftop solar panels when they are usually not at home during peak solar generation hours. Nor does the national framework support community energy, and Portugal's first solar energy cooperative in Lisbon has struggled to gain recognition as an electricity supplier in order to increase the benefits its members can access from the 
addition of solar energy to the electric grid supply mix. Only solar developers installing solar capacity in the Mega Watts (MW), with each MW corresponding to close to a million dollar investment, find themselves able to turn a tidy profit by trading on the wholesale market. This does help in terms of climate change mitigation, as it enlarges the percentage of lowcarbon energy sources feeding the electric grid, and thereby lowers the carbon emissions associated with electricity generation. But, current figures constitute nominal progress, gradual increments, that benefit a few private developers; Portugal is not witnessing some disruptive revolution in the energy sector that benefits tens of thousands of small households and communities and moves rapidly towards a democratic, low-carbon energy future (Camilo et al. 2017; Jaegersberg and Ure 2017; Sareen and Haarstad 2018; see also Jacobson et al. 2017).

So, we find ourselves in a peculiar, but comprehensible, situation. Solar energy is cost-competitive with dirtier energy sources, can be installed in large parts of a country that does not have fossil fuels and, yet, continues to struggle to comprise a significant chunk of Portugal's energy mix. What makes it understandable is the acceptance of a simple, horrifying fact: this is a crisis of accountability, one that flies under the radar even as we animatedly debate sustainable energy transitions within a global system that legitimates pathways of carbon capitalism (Mitchell 2011). Lisbon has hosted some of the most prominent global meetings on such matters, such as Sustainable Energy for All in 2018, and has even been awarded the label of European Green Capital 2020. Do such overt public displays of commitment to the ideal of sustainable energy transition serve as a spectacle that disguises or substitutes for a lack of ambition, action and implementation (Sareen and Grandin in review)? What other horrors lie in store if we extend our gaze to various energy transitions elsewhere, and would it help to call them out? What if we reframe energy transitions as a response to accountability crises? In order to do so, we must articulate how such accountability crises are upheld. What magic is this that keeps them going? I argue next that this 'magic' manifests as discrete practices of legitimation.

\subsection{Deconstructing Accountability into Practices OF LEGITIMATION}

I claim above that we know what the problem is, that we know how to solve it and yet do little about it, and that this disjuncture constitutes a crisis of accountability. Commenting on our contemporary efforts to 
undertake energy transitions and meet the climate challenge at the United Nations High Level Political Forum 2018 in New York, Alex Steffen pointed out to the world that in this case, winning slowly is the same as losing (also see McKibben 2017), and underscored a predatory delay by powerful actors with entrenched interests, both commercial and political. Greta Thunberg addressed an audience of the rich in Davos stating that it is now time to panic. The IPCC released a special report on keeping global warming below $1.5^{\circ} \mathrm{C}$, showing that we have our work cut out and must make critical advances by 2030 . The exponential climate action roadmap 2018 highlighted proven technological solutions that already exist and can cut our emissions by half every decade till 2050 , pointing out policy, political will and other blocks as the chief barriers to overcome (Falk et al. 2018). But, how can dramatic action proportionate to current drastic circumstances be enabled, when those in corridors of power do not feel the same heat, when the privileged maintain the illusion of time while the poor burn in wildfires and suffer climate risk and uncertainty over already vulnerable livelihoods? The energy sector has long been regarded as technical, is often run bureaucratically and technocratically, and is financed in deeply entrenched ways that remain far from transparent (Szulecki 2018) - is the first step towards decarbonising this sector (for decarbonise it we must) to bring it into public discourse as something that concerns us all, as a sector that we all have a stake in steering together?

These questions have answers. They have long been discussed by environmental governance scholars as a matter of accountability in various cognate sectors and a range of academic disciplines. Who makes decisions about resource use and allocation, and how are they held to account (Kraft and Wolf 2018) and by whom? This is partly a question of formal institutional authority - in whom society has vested the power to decide. But the world is rarely limited to formal structures alone. Authority is often contested, raw power sometimes prevails and, sometimes, the powerful are simply too powerful to be held to account by the standards that might appease a moral philosopher (Sareen 2016). And yet, powerful actors and organisations always seek ways to legitimate their power to wider publics to create a new moral economy in which they can take on the roles of new institutional authorities (de Sardan 1999; Sareen 2017). This is not simply attributable to some assumed innate desire in these actors to be recognised as authoritative; the explanation is simpler. Authority makes it easier for power to endure without constantly battling resistance (Scott 1998; Sivaramakrishnan 2005). 
Authority comes from legitimation; hence, it affords its bearer the practical privilege of being able to claim recognition as the one with the right to make important decisions. Ordinary actors have to organise themselves and contest against the odds to secure outcomes that go against a systematised norm-this is the stuff of public protest, legal appeals and riots on the streets. Institutional authority can claim to uphold the system in executing its decisions; it need only cloak them in the guise of what has already been deemed socially acceptable, what is already valid because it is an outcome of due process (Ferguson 1990). Power legitimated as authority freezes legitimacy as embodied in action by virtue of the doer, rather than as a property of the act itself. The onus is on ordinary actors to validate both their claims and an alternative morality in order to challenge particular acts, whereas authoritative institutions use a range of garbs to validate acts.

Such a de facto understanding of authority as not being limited to traditional formal structures complicates how one understands accountability. Emerging scholarship on polycentric climate governance has articulated some of the challenges-accountability cannot be construed as pertaining solely to the state along some vertical and horizontal relations within a centralised and delegated governance framework because this is not an accurate descriptor of how climate governance is, in fact, conducted (Jordan et al. 2018; Bäckstrand and Kuyper 2017). Rather, there are many actors in the folds, each hankering after their own version of what transitions to sustainability should look like. Intergovernmental bodies co-exist with city networks co-exist with aligned interests between business and politics co-exist with federated civil society organisations, each staking its claims (Coenen et al. 2012). Who is to be held accountable for what? Each would have its success measured along customised metrics that favour its ability to showcase progress on sustainability (Kramarz and Park 2016), which runs the risk of double counting many successes that actors see as low-hanging fruit while sidelining attention to intractable problems nobody wants to be held responsible to address (Osofsky 2013).

As with climate governance, so is the case with transitioning energy sectors, albeit these transitions more commonly concern national and regional scales rather than global ones. Fossil fuel actors have entrenched interests, usually complemented by deep political and financial reach, and many are transitioning into leveraged positions in the expanding renewable energy sector, which is also populated by new actors such as solar developers. 
Traditional authorities like ministries are changing their names and structures, demonstrating a commitment to an energy transition or even an ecological transition, responding to and reshaping social imaginaries (Tidwell and Tidwell 2018). Regulatory bodies are grappling with more complex issues than ever before with the advent of the 'smart grid' and questions of big data, ownership and privacy alongside energy efficiency, dynamic tariffs and prosuming (Sareen and Rommetveit 2019). There is emerging excitement linked with energy storage and the prospects of a highly flexible grid where electricity can be stored at decentralised nodes, opening up options for massive shares of renewable energy sources to be integrated into the grid supply mix. This is as complicated and technical as it sounds, and traditional authorities do not readily have the expertise at hand to deal satisfactorily with these questions, let alone inform and consult the wider public affected by the outcomes of these complex decisions. This is the recipe for an accountability crisis if ever there was one-technology is changing fast, institutional authority is being reconfigured and the basis for public oversight is lacking across key aspects of sectoral evolution (Jasanoff 2018; Delina and Janetos 2018). Energy futures are being decided but by whom, and how do those who will be affected-namely, the public-hold someone accountable, when both decision-making processes and decisions themselves appear to be so fuzzy and fluid?

This book, like Kraft and Wolf (2018), suggests that a closer link between legitimacy and accountability will help. What the problem outlined above needs is a relational understanding of accountability that focuses on relations between entities rather than on essentialist, fixed definitions of entities themselves (Bouzarovski and Haarstad 2018). Such a relational ontology is suitable to the context of fluid authority over decision-making and the shifting population of actors described as characterising contemporary energy sectors. How, then, are these relations of accountability constituted? In the present definition, this production of accountability takes place through discrete acts of legitimation. Practices of legitimation thus become relational constituents of accountability. They are empirically observable and contestable, as signifiers and enablers of deeper changes in institutional authority. A repertoire of these practices legitimates new acts and inflects accountability relations. It thereby serves as an adjustment mechanism for more embedded institutional logics (e.g., modest solar uptake to claim a commitment to sustainability while continuing reliance on fossil fuels), or as a transformational moment that alters these logics (e.g., exponential solar uptake as a response to the 
emerging new economics of the energy sector). To understand, and eventually influence, accountability in transitioning energy sectors, we must, therefore, attend to practices of legitimation that embody changing relations between entities. We can thus examine and reveal in what instances and to what extent they signify accountable modes of governance to enable sustainable energy transitions or not.

\section{REFERENCES}

Bäckstrand, K., \& Kuyper, J. W. (2017). The democratic legitimacy of orchestration: The UNFCCC, non-state actors, and transnational climate governance. Environmental Politics, 26(4), 764-788.

Bouzarovski, S., \& Haarstad, H. (2018). Rescaling low-carbon transformations: Towards a relational ontology. Transactions of the Institute of British Geographers. In press, https://doi.org/10.1111/tran.1227514

Camilo, F. M., Castro, R., Almeida, M. E., \& Pires, V. F. (2017). Economic assessment of residential PV systems with self-consumption and storage in Portugal. Solar Energy, 150, 353-362.

Coelho, M. B., Cabral, P., \& Rodrigues, S. (2017). Solar photovoltaic farms suitability analysis: A Portuguese case-study. International Journal of Renewable Energy Research (IJRER), 7(1), 243-254.

Coenen, L., Benneworth, P., \& Truffer, B. (2012). Toward a spatial perspective on sustainability transitions. Research Policy, 41(6), 968-979.

Dansou, K., \& Langley, A. (2012). Institutional work and the notion of test. Management, 15(5), 503-527.

de Sardan, J. O. (1999). A moral economy of corruption in Africa? The Journal of Modern African Studies, 37(1), 25-52.

Delicado, A., Figueiredo, E., \& Silva, L. (2016). Community perceptions of renewable energies in Portugal: Impacts on environment, landscape and local development. Energy Research \& Social Science, 13, 84-93.

Delicado, A., Junqueira, L., Fonseca, S., Truninger, M., \& Silva, L. (2014). Not in anyone's backyard? Civil society attitudes towards wind power at the national and local levels in Portugal. Science \& Technology Studies, 27(2), 49-71.

Delina, L., \& Janetos, A. (2018). Cosmopolitan, dynamic, and contested energy futures: Navigating the pluralities and polarities in the energy systems of tomorrow. Energy Research o Social Science, 35, 1-10.

Falk, J., Gaffney, O., Bhowmik, A. K., Borgström-Hansson, C., Pountney, C., Lundén, D., ... Shalit, T. (2018). Exponential climate action roadmap. Stockholm: Future Earth Sweden. Retrieved from http://exponentialroadmap.futureearth.org 
Ferguson, J. (1990). The anti-politics machine: 'Development', depoliticization and bureaucratic power in Lesotho. Cambridge: Cambridge University Press.

Fortes, P., Simoes, S. G., Gouveia, J. P., \& Seixas, J. (2019). Electricity, the silver bullet for the deep decarbonisation of the energy system? Cost-effectiveness analysis for Portugal. Applied Energy, 237, 292-303.

Jacobson, M. Z., Delucchi, M. A., Bauer, Z. A., Goodman, S. C., Chapman, W. E., Cameron, M. A., ... Erwin, J. R. (2017). 100\% clean and renewable wind, water, and sunlight all-sector energy roadmaps for 139 countries of the world. Joule, $1(1), 108-121$.

Jaegersberg, G., \& Ure, J. (2017). The Portuguese case: The cost of inequality. In Renewable energy clusters (pp. 63-83). Cham: Springer.

Jasanoff, S. (2018). Just transitions: A humble approach to global energy futures. Energy Research \& Social Science, 35, 11-14.

Jordan, A., Huitema, D., Van Asselt, H., \& Forster, J. (Eds.). (2018). Governing climate change: Polycentricity in action? Cambridge: Cambridge University Press.

Kraft, B., \& Wolf, S. (2018). Through the lens of accountability: Analyzing legitimacy in environmental governance. Organization \& Environment, 31(1), 70-92.

Krajačić, G., Duić, N, \& da Graça Carvalho, M. (2011). How to achieve a 100\% RES electricity supply for Portugal? Applied Energy, 88(2), 508-517.

Kramarz, T., \& Park, S. (2016). Accountability in global environmental governance: A meaningful tool for action? Global Environmental Politics, 16(2), 1-21.

Lockwood, M., Kuzemko, C., Mitchell, C., \& Hoggett, R. (2017). Historical institutionalism and the politics of sustainable energy transitions: A research agenda. Environment and Planning C: Politics and Space, 35(2), 312-333.

Mason, M. (2008). The governance of transnational environmental harm: Addressing new modes of accountability/responsibility. Global Environmental Politics, 8(3), 8-24.

McKibben, B. (2017, December 4). Winning slowly is the same as losing. Rolling Stone.

Mitchell, T. (2011). Carbon democracy: Political power in the age of oil. London and New York: Verso Books.

Osofsky, H. M. (2013). The geography of solving global environmental problems: Reflections on polycentric efforts to address climate change. New York Law School Law Review, 58, 777-827.

Pareja-Alcaraz, P. (2017). Chinese investments in Southern Europe's energy sectors: Similarities and divergences in China's strategies in Greece, Italy, Portugal and Spain. Energy Policy, 101, 700-710.

Sareen, S. (2016). Seeing development as security: Constructing top-down authority and inequitable access in Jharkhand. South Asia Multidisciplinary Academic Journal, 13. https://doi.org/10.4000/samaj.4146 
Sareen, S. (2017). Discourses around logging: The moral economy of wood extraction from West Singhbhum's conflicted forests. South Asia: Journal of South Asian Studies, 40(4), 862-877.

Sareen, S. (in review). Metrics for an accountable energy transition? Legitimating the governance of solar uptake. Manuscript under review.

Sareen, S., Baillie, D., \& Kleinwächter, J. (2018). Transitions to future energy systems: Learning from a community test field. Sustainability, 10(12), 4513.

Sareen, S., \& Grandin, J. (in review). European green capitals: Branding, spatial dislocation or catalysts for change? Revised and resubmitted manuscript.

Sareen, S., \& Haarstad, H. (2018). Bridging socio-technical and justice aspects of sustainable energy transitions. Applied Energy, 228, 624-632.

Sareen, S., \& Rommetveit, K. (2019). Smart gridlock? Challenging hegemonic framings of mitigation solutions and scalability. Environmental Research Letters. In press, https://doi.org/10.1088/1748-9326/ab21e6

Scott, J. C. (1998). Seeing like a state: How certain schemes to improve the human condition have failed. Yale University Press.

Sivaramakrishnan, K. (2005). Introduction to "moral economies, state spaces, and categorical violence". American Anthropologist, 107(3), 321-330.

Sovacool, B. K. (2016). How long will it take? Conceptualizing the temporal dynamics of energy transitions. Energy Research \& Social Science, 13, 202-215.

Szulecki, K. (2018). Conceptualizing energy democracy. Environmental Politics, $27(1), 21-41$.

Tidwell, J. H., \& Tidwell, A. S. (2018). Energy ideals, visions, narratives, and rhetoric: Examining sociotechnical imaginaries theory and methodology in energy research. Energy Research \& Social Science, 39, 103-107.

Vasconcelos, J.. (2018). Testimony before the Portuguese Parliament on July $11,2018$.

West, K., \& Davis, P. (2011). What is the public value of government action? Towards a (new) pragmatic approach to values questions in public endeavours. Public Administration, 89(2), 226-241.

Winskel, M. (2018). Beyond the disruption narrative: Varieties and ambiguities of energy system change. Energy Research \& Social Science, 37, 232-237. 


\section{S. SAREEN}

Open Access This chapter is licensed under the terms of the Creative Commons Attribution 4.0 International License (http://creativecommons.org/licenses/ by $/ 4.0 /$ ), which permits use, sharing, adaptation, distribution and reproduction in any medium or format, as long as you give appropriate credit to the original author(s) and the source, provide a link to the Creative Commons licence and indicate if changes were made.

The images or other third party material in this chapter are included in the chapter's Creative Commons licence, unless indicated otherwise in a credit line to the material. If material is not included in the chapter's Creative Commons licence and your intended use is not permitted by statutory regulation or exceeds the permitted use, you will need to obtain permission directly from the copyright holder.

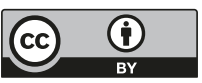




\title{
A Typology of Practices of Legitimation to Categorise Accountability Relations
}

\author{
Siddharth Sareen
}

\begin{abstract}
This chapter presents the central element of an accountability analysis approach - a typology of four practices of legitimation: discursive, bureaucratic, technocratic and financial. These are empirically derived and defined in generic terms as social relations premised on accountability. Their study can characterise accountability under energy transitions. Discursive legitimation practices normalise certain perspectives over others through textual and spoken interventions across a variety of forums. Bureaucratic legitimation practices, often codified and sequential, validate some actions and actors and constrain others. Technocratic legitimation practices perform systematic checks and approval of actions that entail technical expertise. Financial legitimation practices, often spatially remote and materially elusive, enable actors to block action or to fulfil financial requirements and proceed with material actions, shaping sectoral change.
\end{abstract}

Keywords Practices of legitimation $\bullet$ Discursive $\bullet$ Bureaucratic $\bullet$ Technocratic $\bullet$ Financial

\footnotetext{
S. Sareen $(\bowtie)$

Department of Geography, Centre for Climate and Energy Transformation, University of Bergen, Bergen, Norway e-mail: Siddharth.Sareen@uib.no

(C) The Author(s) 2020

S. Sareen (ed.), Enabling Sustainable Energy Transitions, https://doi.org/10.1007/978-3-030-26891-6_2
} 
There is an endless variety of practices of legitimation. But they draw on a number of common registers. Four such registers surfaced clearly from empirical research on solar energy uptake in Portugal during 2017-2019. These empirically derived registers are put forward as a typology of practices of legitimation. They are:

- Discursive legitimation

- Bureaucratic legitimation

- Technocratic legitimation

- Financial legitimation

Without elaborating the empirical basis for this typology, detailed elsewhere (Sareen in review), and without extending the initial foray into the Portuguese case, this chapter unpacks each of these four types of practices: what do they mean? Furthermore, it puts forward a few preliminary suggestions for how this typology is supported by extant research on accountability and legitimacy within environmental governance. Environmental governance research has on the whole been rather laggardly in taking up the important question of sustainable energy transitions at disaggregated scales (Falkner 2014; Smith and Stirling 2010), so this connection between its treatment of accountability and legitimacy and their application to the energy sector is overdue (Szulecki 2018). It is a task that requires multiple perspectives and many person-years of research. This book enlists the support of select colleagues who have an appreciation of both environmental governance and energy transitions scholarship. This chapter kickstarts the conversation by laying out the types of practices of legitimation. Then, Part II opens with an explanation of the invitation (Chap. 3) issued to the authors of five subsequent case chapters, each of which presents a perspective on accountable governance under energy transitions, drawing on the case author's own empirical research (Chaps. 4, 5, 6, 7 and 8). The concluding Part III synthesises learning about the analytical usefulness of practices of legitimation across the five cases (Chap. 9), then features collective reflection on how future environmental governance scholarship can generate analytical insights on accountability (Chap. 10). The book seeks both to guide the uptake of accountability within theoretical and applied energy transitions research in a broad range of fields and disciplines, and to inform strategic action, thereby contributing to both analysing energy sector transitions and enabling accountable governance towards sustainability. 
With each type of practice of legitimation below, the intent is to fashion tools that can deconstruct what acts are being justified and validated (i.e., legitimated) by whom, to whom and in what manner. Each type of practice surfaces a specific register along which it evinces accountability relations that display commitment to sustainable outcomes. Within any given energy sector context, each type of practice is empirically observable to a sufficient degree to identify specific problem areas, accountability lacunae, scope for further gains and to challenge claims, and to pose normative questions of who gets to decide, and who should be consulted or otherwise involved.

\subsection{Discursive Legitimation}

Discursive legitimation refers to a set of practices that normalise certain perspectives over others through textual and spoken interventions across a variety of forums. These forums range from highly technical discussions among a narrow group of actors to mainstream debates for audiences as wide as the general public in the pages of national newspapers. Practices of legitimation manifest in many ways on these platforms: speaking in favour of one choice over another, thus advocating for something; referring to some things as commonplace and thereby stabilising them as a public imaginary; talking down some possibilities as being a threat to other desirable outcomes, thus creating or strengthening cognitive links; repeating the need for something as a matter of social necessity and thereby building public support for it; and dismissing some options as wishful thinking uninformed by reality, thus tightening the discursive space that might allow their propagation. These practices are all relational in the sense that they are enacted by actors in relation to audiences, and also because they position ideas in specific relation to other ideas.

A politician backing continued reliance on fossil fuels may, for instance, decry renewable energy sources as posing a debt burden on the public. A federation of solar energy developers may issue a statement against this, pointing out that they are able to compete with coal thermal plants without any public subsidies. Coal thermal plant owners may lobby national regulators to maintain the status quo in the energy sector, which has historically rewarded their power source as relatively 'reliable'. Energy market analysts may point out that this logic has changed, as greater interconnections between electric grids allow for more flexibility in energy sources. Those concerned with energy security might contend that more 
interconnections pose a threat to sovereignty due to increased reliance on neighbouring countries. Geopolitical experts might counter this argument by pointing out that greater interdependency can in fact foster regional cooperation. Each of these actors would be articulating their particular interests in relation to other competing or complementary perspectives, picking platforms and orders of worth that favour their message or ones that are crucial for securing particular desirable outcomes (von BendaBeckmann 1981; Boltanski and Thévenot 2006; Patriotta et al. 2011), be it parliamentary hearings, newspaper columns, online blogs, public consultations on new sectoral policies, electoral rallies, thematic conferences, annual expos or even urban festivals.

What makes these practices relevant for the examination of accountability in energy transition is that they lend themselves to empirical study (Moezzi et al. 2017). They allow a contextualised appreciation of different actors' interests and how they articulate them in a disaggregated manner. This extends to actors within organisations as well, as a given organisation rarely consistently represents a single perspective on a complex issue such as energy transition. If one understands energy sector governance as comprising an assemblage of actors (cf. Rose 1999) - governmental institutions, emerging authorities such as ad hoc commissions for specialised decisions, private companies, citizen associations, administrative bodiesthen practices of discursive legitimation offer insight into the numerous and shifting relations between this diverse mix of actors. Tweets by a key decision-maker, for instance, have lately emerged as a new way to keep up with the latest developments in a fast-changing sector, and offer new opportunities for public responsiveness-key figures can note and respond directly to comments by ordinary individuals-while also providing insight into the views of individuals within formal organisations (Morgan et al. 2018). Discursive legitimation is also susceptible to hegemonic tendencies-particular accounts can 'go viral' and spread rapidly, often exercising significant influence by shaping readers' or listeners' perceptions. Meanwhile, more detailed and often better substantiated claims such as those in academic articles can remain largely disregarded even by key decision-makers who usually have busy schedules and little time to access paywalled manuscripts that use heavy language.

Practices of discursive legitimation thus play a key role in energy transition: validating particular acts and shoring up the credibility of institutional authorities and their decisions against critique; issuing challenges to specific decisions and even decision-making processes and suggesting 
alternatives, thus opening up space for debate and the emergence of competing actors; and closing down particular claims by pointing to countervailing accounts, often more established ones with some formal backing. Observation and analysis of which actors legitimate what sort of action and on what basis, which actors level competing claims, and the platforms they pick to address specific target audiences, can furnish a telling picture of a given energy transition. Is it driven by a culture of informed public engagement, healthy debate, friendly critique and an effort at reflexive learning by authoritative institutions in the sector? Or are there several opposing camps, with those currently in a position of authority trying to maintain the status quo and others challenging their authority, vying to constitute their own authority, or to simply improve their position within structural limits they dare not challenge?

Discursive legitimation provides insight into this power interplay precisely because it serves as a means by which actors legitimate their own positions and decisions (Haarstad et al. 2018). In an ideal world, it enables deliberation along democratic lines to institute accountability in the manner in which energy transitions are discussed and implemented (Späth and Rohracher 2010). Deliberative democracy remains hard to obtain in most political contexts, and a technical sector like energy hardly lends itself easily to informed public debate and engagement. Given its bureaucratic, often top-down history, a transition in this sector faces a real challenge to engender energy democracy, with the norm having long been to leave decision-making in the hands of narrow groups of experts (Sareen 2018). Examining discursive legitimation, then, is a sound approach to also identify specific opportunities to build public accountability into energy transitions.

\subsection{Bureaucratic Legitimation}

Bureaucratic legitimation pertains to practices, often codified and sequential, that validate some actions and actors and limit the range of possibilities for other actors. Readers will be familiar with bureaucracy as a particular method of ensuring conformity with existing laws and regulations (Ferguson and Gupta 2002). For instance, actors might have to furnish proof of a certain competence or qualification in order to secure approval necessary to take on a formal role, operate a private enterprise or maintain access to public services. Bureaucracy is ubiquitous; it is part of the paraphernalia of daily life whereby we conduct our everyday affairs. It also 
serves essential functions within society and is inevitable. But the flip side is that it accretes redundant requirements, conditions that are an artefact of old ways but remain embedded in current protocols due to inadequate adaptiveness by an organisation during sectoral change. Actors who have to meet such bureaucratic residue might protest and push for a change in formal requirements, an update, or they might find themselves in a position where they are unable to appeal due to limited time, financial wherewithal or a legal framework that, in turn, poses its own bureaucratic challenges. Authorities imposing bureaucratic requirements are often painfully well aware of the privilege their position accords them; depending on internal mechanisms to ensure checks and balances, particular individuals might even seek to abuse this privilege for personal gain, which is usually referred to as petty corruption.

There are several other aspects to bureaucratic legitimation (cf. Suchman 1995), such as a likely bias in favour of incumbent actors, and against emergent actors, on whom falls the onus to validate themselves and fulfil numerous existing requirements - to learn the rules of the game (Geels and Schot 2007). This is a potentially desirable trait in a wellfunctioning system to ensure system reliability and security, but poses challenges when change is imperative as in the case of energy transitions to address the urgent climate challenge. Several other relational tendencies also surface: there are likely to be information flow asymmetries, as practices in most sectors and contexts tend to feature a partially informal component. There is a risk that bureaucratic processes will extend processing time for critical decisions (Crawford 2015), lowering policy visibility during sectoral change and disadvantaging actors who are worst affected by ensuing uncertainty. And there is a further question concerning time and positionality: those who are well placed to devise bureaucratic requirements have often been closely acquainted with a sector for a long period, and hence, their embodied memory is of a certain mode of conducting affairs that is liable to often resemble business as usual (Sareen 2018; Szeman 2013). The bureaucratic mechanisms they proffer might thus favour the status quo and incumbent actors, allowing tacit bias to creep in. This risk is exacerbated by the fact that entrenched actors often occupy key positions from which to lobby and influence decision-makers in their sector; they can challenge and effectively quash protests from emergent actors by pointing to their superior experience and historically stellar credentials. When changes do come about, such actors can again leverage their positions to modulate what new bureaucratic frameworks are put in play 
(Grandin and Sareen in review). This not only equips them with a potential information advantage, it also suggests that key actors can orchestrate sectoral change to unfold in a manner that works to their advantage over others without being held to account for their self-serving exercise of undue influence.

For instance, during energy sector transitions, solar developers might find themselves faced with the need to secure a number of different licences: to lease land for up to three decades, to conduct basic environmental impact assessments, to access grid infrastructure, to import solar modules and to gain the right to provide a certain quantum of stable supply to the electric grid over a stated period or to enter into bilateral contracts with users, to mention a few examples. These constitute practices of bureaucratic legitimation, and actors who are unable to navigate such demands might find themselves shut out from being able to participate as solar developers. An appropriate amount of bureaucratic process is important to secure requisite oversight over a number of interlocked functions in a technical sector like energy (Sareen and Kale 2018); a well-conceived bureaucratic system can feature in-built corrective measures that function as accountability mechanisms, internalised checks and balances. But what complicates matters is when bureaucratic requirements display overly zealous reach or are simply biased towards or against a particular technology or set of actors-especially emerging ones who tend to have less social capital-to an extent that interferes with the efficient functioning of the sector.

Sometimes such bureaucratic interference is expressly permitted and justified on normative grounds - renewable energy may be permitted to go ahead up to a certain component of the total energy supply, so as to meet clean energy targets as a percentage of the grid mix, consequently loosening up bureaucratic requirements for renewable producers up to this target. Yet, normative commitments are not always clearly articulated-fossil fuels are accorded numerous subsidies, both historically in terms of existing energy infrastructure and directly at present, to an extent that other sources would find it impossible to secure through any number of bureaucratic processes (Asmelash 2015). Bureaucratic preferences are not always easy to discern. Wholesale energy trading markets, for instance, follow bureaucratic sets of rules that have evolved historically in energy sectors with relatively small components of renewable energy, and as this proportion changes, the rules do not necessarily change in ways that are optimal for the grid or fair in terms of their effects on various actors, not 
least on the citizens and users whom the energy sector should serve in a manner responsive to their evolving needs. As part of energy transitions, these could include regulatory frameworks for individuals and communities to prosume and receive appropriate compensation for power sold to the grid from rooftop solar panels.

Studying such practices of bureaucratic legitimation can be challenging, but is an essential component of identifying whether and how energy transitions can proceed with public accountability (Kalkuhl et al. 2013; Saltzstein 1979). Such examination must often be undertaken in several locations across multiple scales (Krause and Meier 2005)—down the corridors of power where bureaucracy is executed; in policy documents, where its formal contours are delineated; by listening to the accounts of actors who claim they are marginalised; through attention to emergent material changes that open new possibilities and how these possibilities are bureaucratised; and by triangulating between the various concurrent changes in bureaucratic requirements during sectoral evolution (Sareen and Kale 2018). Where such examination uncovers bureaucratic mediation that forecloses opportunities for energy transition to aid decarbonisation and social equity, these practices can be specifically challenged to build accountability gains within specific contexts of energy transition.

\subsection{Technocratic Legitimation}

Technocratic legitimation refers to a set of practices that perform systematic checks and approval of actions that entail technical expertise. This is distinct from bureaucratic legitimation in that it extends beyond filling forms or ticking boxes to secure validation from a designated authority, to a practice that is itself substantive along the same register as the action that it evaluates for approval. This requires some clarification: practices of technocratic legitimation devise a method to assess whether specific actions by specific actors should be permitted or not, and this method itself exhibits a certain element of sophistication in order to lend credibility to the approval as something that takes place after due consideration of the technicalities involved.

Energy transitions raise many highly technical questions that require expert knowledge and do not always have existing scientific consensus around one answer. There may be several possibilities and a basis is needed to determine which ones to permit and prioritise, and which actors should be in charge of executing them and on what basis (Chilvers and Longhurst 
2016). An important but relatively easy to resolve example is that of the debate between 80 and 100 per cent renewable energy-based systems. While there is still some disagreement on the possibility of complete decarbonisation despite highly detailed analyses of an impressive number of actual contexts in which this should work, it does not complicate too many current decisions, as most energy systems are well short of even 80 per cent renewable energy sources; hence, decisions can be made to decarbonise rapidly, and the question of the final 20 per cent can be resolved later in the energy transition (Jacobson and Delucchi 2009). A more complicated question and one that does require technocratic legitimation is whether a given quantum of new renewable energy capacity can be installed in a decentralised manner and added to an existing electric grid infrastructure. It is important not to overload transmission capacity beyond what the grid can withstand to ensure reliable energy supply and to consider the basis for 'curtailment', which refers to letting surplus power generation simply go unused, or to shutting it down when it runs into grid capacity constraints. Before giving the go-ahead to a number of solar projects, an energy regulator or national ministry would be keen to ensure that the terms on which this new capacity is installed are clear to everyone concerned, marking a clear instance of a case for technocratic legitimation. This is crucial not only to enable energy transitions, but to safeguard citizens against unreliable energy services and debt burdens in case support schemes are not designed to have equitable effects, as well as to prevent losses to the public exchequer, utilities and developers due to inadequate attention to aspects like grid stability and coordination.

This presents an interesting challenge for accountability in energy transitions. When matters are technical, they can hardly be left up to some sort of popular vote, as the public is rarely sufficiently knowledgeable to weigh in usefully on matters of such sophistication. But simply entrusting them to experts risks eventual public backlash, especially in contemporary contexts of rising distrust against authority and the rule of experts; history also bears evidence to the risk of elite capture and large-scale corruption under such conditions (cf. Lennon 2017). Practices of technocratic legitimation present a reasonable compromise-devising a relatively sophisticated system to secure technically appropriate decisions, but with an element of checks and balances and the participation of multiple types of actors who can hold each other accountable. Examples include standing committees, special taskforces and other such ad hoc measures; also more institutionalised mechanisms such as stringent public procurement rules, 
well-defined guidelines for public tenders to ensure competitive bidding on various contracts, and algorithms that automate the allocation of particular opportunities to actors who best fulfil pre-specified and publicised criteria to secure optimal performance.

Yet, both ad hoc and more embedded mechanisms, when situated within a temporal perspective, can be appreciated as facing risks of cooptation and being reduced to an empty shell without securing the very accountable outcomes that their technocratic components are ostensibly put in place to ensure (Hendriks 2009). Actors often move between key organisations in the same sector over time, and collegial and personal networks overlap in complex ways that render secrecy almost impossible, so upcoming changes in assessment or selection routines often set off preemptive adjustments within organisations that are in the loop, even before they are formally announced (Hargreaves et al. 2013). Moreover, sectoral contexts often feature limited expertise within a region or country; hence, expertise is subcontracted in to furnish inputs for terms of reference. This again courts the risk that some well-networked actors may be tipped off in advance of any technocratic legitimation procedures and maximise their chances over competitors.

Probing these relational practices of technocratic legitimation in concrete instances can generate and advance a technically robust and politically informed understanding of energy transitions. Technocratic legitimation is perhaps most visible at times when a sector undergoes rapid change, as effort-intensive mechanisms are put in place to enable change while simultaneously maintaining stability (Pellizzoni 2011). Over time, these practices tend to be absorbed into reconfigured systemic practices and become part of bureaucratic legitimation, which is more routinised and embedded within existing organisational functions. In this sense, practices of technocratic legitimation offer a raw, direct opportunity to shape energy futures towards decarbonisation and enhancement of social equity - by examining, critiquing and adjusting specific practices, it is possible to impact how the energy sector reorientates itself in relation to current changes. This translation function, between experts who are entrusted with framing and conducting technocratic legitimation and the public whose interests they should in principle safeguard, is one that researchers and analysts are well equipped to weigh in on (Fischer 1993). Those who inform themselves of the empirics of technocratic legitimation in a sectoral context can credibly provide policymakers with inputs on specific measures 
they should establish in order to move energy transitions towards sustainability, with a clear basis in evidence.

\subsection{Financial Legitimation}

Financial legitimation pertains to practices, often spatially remote and materially elusive, that enable actors to either block out scope for action, or to fulfil financial requirements and proceed with material actions in order to retain relevance within a sectoral context. They are perhaps the most crucial and telltale signifier of the characteristics of an energy transition-which actors are able to secure financial legitimation, through which practices, for what activities? By structuring the fields of action, capital and access to credit quite directly shape energy transitions (Hess 2014); thus, the practices that make up financial legitimation indirectly capture the core of any sectoral change. One of the refrains iterated by international agencies trying to steer towards rapid global decarbonisation and equitable access to energy has been the need to make much more capital available for universal access to clean energy (also see Polzin et al. 2017); the global divestment movement is trying to push money out of fossil fuel energy to secure contractions of carbon-intensive sources and accelerate investment in renewable energy (Healy and Barry 2017).

Practices of financial legitimation thus render explicit the relevance of spatial and scalar connections. But what practices are observable and how can their study contribute towards more accountable energy transitions? At the household or individual scale, germane issues include determining the appropriate levels of compensation for flexibility added to the grid based on distributed storage, as batteries become affordable and electric vehicles proliferate, as well as disincentives to prevent users from loading the grid during peak demand periods (Sareen and Rommetveit 2019). Several aspects of financial legitimation can in fact be studied in great empirical detail: what are the challenges actors have to face in securing financial backing to install and operate different energy sources; how do these requirements vary across sources; how are these financial parameters set and by which authority? For instance, renewable energy projects face a rather different challenge than fossil fuel projects. Most of their lifetime project costs are concentrated up front: procurement of licences, land and infrastructure. Once equipment is set up and grid connected, operating costs are negligible compared to coal or gas thermal plants which consume a great deal of fuel throughout their lifespan, fuel that additionally often 
has to be brought in from afar. Yet renewable energy projects are often characterised as variable sources and have up to recently faced considerable scepticism from financial institutions regarding their future revenue flows, making it relatively expensive to secure investment capital (Kim and Park 2016).

With the rapid decrease in costs of both wind and, especially, solar energy technologies, these dynamics have begun to shift, and even large fossil fuel majors are beginning to leverage their portfolios with some investments in clean energy. But the challenges are significantly different for relatively small entrants to the energy sector who do not have as much financial weight. By contrast, shell companies have also begun to emerge rapidly as vehicles for speculative financial investments in renewable energy projects. How to maintain an energy sector that remains open to smaller actors while also safeguarding against potentially risky short-term players is a challenge that can only be resolved through a keen appreciation of various practices of financial legitimation (Mazzucato and Semieniuk 2018).

Even tracking these observable practices, however, uncovers only the tip of the proverbial iceberg. When it comes to energy finance, there is little transparency, with large sums and many international organisations involved, leveraging their presence across several different legal regimes including global tax havens. There are thus intrinsic problems to contend with to usher accountability into financial legitimation, and part of the task is to better visualise these global metabolisms at lower scales like the urban and national (Goodman and Marshall 2018). Many cities, regions and countries have begun to track their territorial emissions and set targets at lower scales, including sector specific ones. It is possible that such attempts will be accompanied by fees on high carbon emitters and mass mobilisation of greater investment in renewable energy. Many such initiatives have already been promoted in recent years, but these attempts at alternative financial legitimation have faced stiff resistance in most parts of the world, most notably from the powerful and well-funded fossil fuel lobby that such practices, if successful, directly threaten.

Financial legitimation extends beyond project finance. These practices are also embedded within other processes intrinsic to the everyday operation of the energy sector, such as wholesale and retail market trade. On the wholesale market, fossil fuels such as gas secure high returns due to their flexibility, being available 'on demand', whereas market designs do not always favour renewable energy sources as their percentage of the total supply mix increases rapidly (Ueckerdt et al. 2015). This again is a question 
of what characteristics are seen as worth rewarding financially, and whether the decision is made by default or based on exhaustive public discussion. Likewise on the retail market, rules vary vastly across countries in terms of how much actors such as households and communities can benefit from installing small-scale solar capacity. Another practice of financial legitimation embedded both deeply and historically in the energy sector pertains to investments in energy infrastructure, often made from the public purse, with major consequences for which actors and what energy sources gain support (Jerneck 2017). This support includes both being able to sell electricity to the grid and lowering costs for the energy producer, for instance by co-financing thermal power plant infrastructure by the sea to enable easy access to international coal shipments, a common practice that supports one of the highest carbon emitting sources. Studying the manner in which these issues of financial legitimation are discussed and settled, as well as whom they favour and penalise, can generate key insights into the nature of energy transitions.

Overall, then, practices of financial legitimation are possibly the trickiest to interrogate empirically; doing so is, nonetheless, vital in order to identify the points that warrant the most critical attention for moving towards accountable energy transitions. These practices take place across the spatial scale, but their effects are materialised in the sector, and various reporting mechanisms and mandates as well as investigations by civil society watchdogs render overall trends visible. When it comes to specific actors in a given context, the contrasting demands that financial legitimation places on them can often be clearly explicated, and serve as a basis to challenge and contest practices that maintain power differentials in favour of business as usual. Unpacking this can ease the way for financially competitive renewable energy sources to expand rapidly in a market made more even by bringing accountability into energy sector transitions.

\subsection{Linking Hollow and Substantive Accountability with Sustainability Outcomes}

The articulation of the four types of practices of legitimation that relationally constitute accountability, or the lack of it, in energy sector transitions, paves the way for the final step of the argument in Part I. Overall, any given transition comprises these practices, which can be disaggregated into performances of substantive or hollow accountability. At a 
disaggregated level, most acts can be empirically and relationally categorised as aiding or opposing interlinked shifts towards decarbonisation and social equity under energy transition.

Acts that aid such shifts, and are held to account by practices of legitimation in order to secure a durable outcome of this nature, can be characterised as contributing to a sustainable energy transition. This is a case where practices of legitimation constitute substantive accountability relations. Conversely, acts that oppose such shifts are not substantively held to account by practices of legitimation in the service of sustainable outcomes (Blühdorn 2013). Rather, they are supported by practices of legitimation that constitute a performance of hollow accountability; they support the persistence or even expansion of unsustainable outcomes in the energy sector.

It follows that practices of legitimation provide the basis for a relational toolkit to identify substantive and hollow accountability through empirical study of energy sector transitions. This fine-grained evidencing and analysis of the practices that constitute energy transitions can inform academics, and in turn policymakers, practitioners and the public, about acts that support sustainability and those that hold us back from it. Wielded well, this pickaxe can equip citizens with evidence for their own urgent axes to grind and create a strong push for public accountability to be instituted into energy transitions towards sustainability.

This intent- to contribute to rapid decarbonisation of our energy systems and deeply change whom they benefit, thus addressing climate change drivers and safeguarding public interest-is a guiding beacon. The logical next step after propounding a typology of practices of legitimation is to understand how to situate such an approach within scholarship on energy transitions, so that it can render accountability crises visible in contextualised ways that inform and enable action. To open up space for sustainable outcomes through more accountable governance of energy transitions, it is relevant to take point of departure in the variety of ways in which scholarship on environmental governance approaches accountability in energy transitions. The five case chapters in Part II capture a wide range of cases and different disciplinary perspectives. 


\section{REFERENCES}

Asmelash, H. B. (2015). Energy subsidies and WTO dispute settlement: Why only renewable energy subsidies are challenged. Journal of International Economic Law, 18(2), 261-285.

Blühdorn, I. (2013). The governance of unsustainability: Ecology and democracy after the post-democratic turn. Environmental Politics, 22(1), 16-36.

Boltanski, L., \& Thévenot, L. (2006). On justification: Economies of worth. Princeton, NJ: Princeton University Press.

Chilvers, J., \& Longhurst, N. (2016). Participation in transition(s): Reconceiving public engagements in energy transitions as co-produced, emergent and diverse. Journal of Environmental Policy \& Planning, 18(5), 585-607.

Crawford, A. (2015). Temporality in restorative justice: On time, timing and timeconsciousness. Theoretical Criminology, 19(4), 470-490.

Falkner, R. (2014). Global environmental politics and energy: Mapping the research agenda. Energy Research \& Social Science, 1, 188-197.

Ferguson, J., \& Gupta, A. (2002). Spatializing states: Toward an ethnography of neoliberal governmentality. American Ethnologist, 29(4), 981-1002.

Fischer, F. (1993). Citizen participation and the democratization of policy expertise: From theoretical inquiry to practical cases. Policy Sciences, 26(3), 165-187.

Geels, F. W., \& Schot, J. (2007). Typology of sociotechnical transition pathways. Research Policy, 36(3), 399-417.

Goodman, J., \& Marshall, J. P. (2018). Problems of methodology and method in climate and energy research: Socialising climate change? Energy Research o Social Science, 45, 1-11.

Grandin, J., \& Sareen, S. (in review). What sticks? Ephemerality, permanence and urban transformation pathways. Revised and resubmitted manuscript.

Haarstad, H., Sareen, S., Wanvik, T. I., Grandin, J., Kjærås, K., Oseland, S. E., ... Wathne, M. (2018). Transformative social science? Modes of engagement in climate and energy solutions. Energy Research \& Social Science, 42, 193-197.

Hargreaves, T., Hielscher, S., Seyfang, G., \& Smith, A. (2013). Grassroots innovations in community energy: The role of intermediaries in niche development. Global Environmental Change, 23(5), 868-880.

Healy, N., \& Barry, J. (2017). Politicizing energy justice and energy system transitions: Fossil fuel divestment and a "just transition". Energy Policy, 108, 451-459.

Hendriks, C. M. (2009). Policy design without democracy? Making democratic sense of transition management. Policy Sciences, 42(4), 341.

Hess, D. J. (2014). Sustainability transitions: A political coalition perspective. Research Policy, 43(2), 278-283.

Jacobson, M. Z., \& Delucchi, M. A. (2009). A path to sustainable energy by 2030. Scientific American, 301(5), 58-65. 
Jerneck, M. (2017). Financialization impedes climate change mitigation: Evidence from the early American solar industry. Science Advances, 3(3), el601861.

Kalkuhl, M., Edenhofer, O., \& Lessmann, K. (2013). Renewable energy subsidies: Second-best policy or fatal aberration for mitigation? Resource and Energy Economics, 35(3), 217-234.

Kim, J., \& Park, K. (2016). Financial development and deployment of renewable energy technologies. Energy Economics, 59, 238-250.

Krause, G. A., \& Meier, K. J. (Eds.). (2005). Politics, policy, and organizations: Frontiers in the scientific study of bureaucracy. University of Michigan Press.

Lennon, M. (2017). Decolonizing energy: Black Lives Matter and technoscientific expertise amid solar transitions. Energy Research \& Social Science, 30, 18-27.

Mazzucato, M., \& Semieniuk, G. (2018). Financing renewable energy: Who is financing what and why it matters. Technological Forecasting and Social Change, $127,8-22$.

Moezzi, M., Janda, K. B., \& Rotmann, S. (2017). Using stories, narratives, and storytelling in energy and climate change research. Energy Research \& Social Science, 31, 1-10.

Morgan, K., Cheong, M., \& Bedingfield, S. (2018). "Power to the people!": Social media discourse on regional energy issues in Australia. Australasian Journal of Information Systems, 22. In press, https://doi.org/10.3127/ajis. v22i0.1678

Patriotta, G., Gond, J. P., \& Schultz, F. (2011). Maintaining legitimacy: Controversies, orders of worth, and public justifications. Journal of Management Studies, 48(8), 1804-1836.

Pellizzoni, L. (2011). The politics of facts: Local environmental conflicts and expertise. Environmental Politics, 20(6), 765-785.

Polzin, F., Sanders, M., \& Täube, F. (2017). A diverse and resilient financial system for investments in the energy transition. Current Opinion in Environmental Sustainability, 28, 24-32.

Rose, N. (1999). Powers of freedom: Reframing political thought. Cambridge: Cambridge University Press.

Saltzstein, G. (1979). Representative bureaucracy and bureaucratic responsibility: Problems and prospects. Administration \& Society, 10(4), 465-475.

Sareen, S. (2018). Energy distribution trajectories in two Western Indian states: Comparative politics and sectoral dynamics. Energy Research \& Social Science, $35,17-27$.

Sareen, S. (in review). Metrics for an accountable energy transition? Legitimating the governance of solar uptake. Manuscript under review.

Sareen, S., \& Kale, S. S. (2018). Solar 'power': Socio-political dynamics of infrastructural development in two Western Indian states. Energy Research o Social Science, 41, 270-278. 
Sareen, S., \& Rommetveit, K. (2019). Smart gridlock? Challenging hegemonic framings of mitigation solutions and scalability. Environmental Research Letters. In press, https://doi.org/10.1088/1748-9326/ab21e6

Smith, A., \& Stirling, A. (2010). The politics of social-ecological resilience and sustainable socio-technical transitions. Ecology and Society, 15(1). Retrieved from http://www.ecologyandsociety.org/voll5/issl/artl1/

Späth, P., \& Rohracher, H. (2010). 'Energy regions': The transformative power of regional discourses on socio-technical futures. Research Policy, 39(4), 449-458.

Suchman, M. C. (1995). Managing legitimacy: Strategic and institutional approaches. Academy of Management Review, 20(3), 571-610.

Szeman, I. (2013). How to know about oil: Energy epistemologies and political futures. Journal of Canadian Studies/Revue d'études canadiennes, $47(3), 145-168$.

Szulecki, K. (2018). Conceptualizing energy democracy. Environmental Politics, $27(1), 21-41$.

Ueckerdt, F., Brecha, R., \& Luderer, G. (2015). Analyzing major challenges of wind and solar variability in power systems. Renewable Energy, 81, 1-10.

von Benda-Beckmann, K. (1981). Forum shopping and shopping forums: Dispute processing in a Minangkabau village in West Sumatra. The Journal of Legal Pluralism and Unofficial Law, 13(19), 117-159.

Open Access This chapter is licensed under the terms of the Creative Commons Attribution 4.0 International License (http://creativecommons.org/licenses/ by $/ 4.0 /$ ), which permits use, sharing, adaptation, distribution and reproduction in any medium or format, as long as you give appropriate credit to the original author(s) and the source, provide a link to the Creative Commons licence and indicate if changes were made.

The images or other third party material in this chapter are included in the chapter's Creative Commons licence, unless indicated otherwise in a credit line to the material. If material is not included in the chapter's Creative Commons licence and your intended use is not permitted by statutory regulation or exceeds the permitted use, you will need to obtain permission directly from the copyright holder.

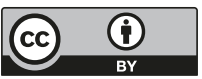


PART II

Cases 


\title{
Five Easy Pieces: Legitimation at Work in Cases Related to Energy Transitions
}

\author{
Siddharth Sareen
}

\begin{abstract}
This chapter provides an overview of five energy transition cases by describing the questions posed to five authors to guide the flow of argument in their chapters and summarising case treatments with respect to accountability and legitimation. It links four proposed practices of legitimation with analytical takes on wide-ranging cases. The cases span urban energy transitions over time and space in Germany, forest and land conflicts over authority in Indonesia, urban climate targets based on carbon metrics in Norway, the modalities of Nordic electric mobility transitions, and biodiversity conservation and energy extraction in the USA. Pinpointing the relevance of each case to legitimation, this chapter explicates how questions of accountability are germane to how the energy transitions associated with these cases impact sustainability.
\end{abstract}

Keywords Accountability $\bullet$ Crisis $\bullet$ Energy transitions $\bullet$ Legitimacy $\bullet$ Sustainability

\footnotetext{
S. Sareen $(\bowtie)$

Department of Geography, Centre for Climate and Energy Transformation, University of Bergen, Bergen, Norway e-mail: Siddharth.Sareen@uib.no

(C) The Author(s) 2020

S. Sareen (ed.), Enabling Sustainable Energy Transitions, https://doi.org/10.1007/978-3-030-26891-6_3
} 
It is imperative that we bear in mind the deep variation in how energy transitions are experienced by different actors, and that their ability to exercise their stakes in the outcomes differs by orders of magnitude. Part I reframed energy transitions as a response to accountability crises, deconstructed accountability into practices of legitimation and presented a typology of those practices. The cases in Part II surface a number of complex spatiotemporal conjunctures and deconstruct the climate and energy crises entangled therein.

If even privileged academics at Global North institutions, wellresourced and relatively free to choose our own research themes, were to shy away from attempts to mobilise knowledge to inform and steer action and hold power accountable, it would spell little hope for sustainable futures. These cases, and the collaborative project ensconcing them, constitute an argument that we can in fact make a meaningful difference, that we have a crucial role to play in making energy transitions accountable and directed towards sustainable outcomes. This is our contribution to make in addressing the climate crisis for those at risk today to have livable futures.

Accordingly, this middle section of the book provides short overviews of cases relevant to energy transitions in a variety of sectors and regions, with a focus on legitimation and accountability in the governance of environmental change. Each of the five chapters is authored by an accomplished environmental governance scholar working on energy transition cases and kindred subjects. Each has reframed their work on a particular case in terms of crises of accountability and practices of legitimation. The following questions guide their independently composed individual responses and constitute a general flow of argument:

- What is the case and why is it an energy transitions case?

- What crises of accountability are being maintained or challenged?

- How do environmental governance scholars characterise the case?

- What practices of legitimation appear to be at play in empirical work?

- What interventions could enable sustainable outcomes under transition?

Timothy Moss draws on the governance of urban energy infrastructure across time and space to unpack the changing relationship between energy transitions, accountability and practices of legitimation across the formidable range of contextual variation in Berlin over the past century. His historical analysis of accountability in the changing contexts that drove 
energy transitions in this city over the course of a century of political flux surfaces many potent concerns. Among these is the difficulty of evaluating past transitions in relation to sustainability, which only appeared in its familiar current form from the 1970s onwards and has gained notable attention beyond academia even more recently, mainly in the twenty-first century. He also foregrounds that accountability crises are not a new concern but rather have deep roots. What is new, in this sense, is the relevance of sustainability as a concern linked with energy transitions, which directs our attention in this book to accountability crises that are only beginning to be sufficiently recognised. Moss' historical analysis of Berlin's energy transitions, moreover, emphasises the context specificity of accountability as relationally negotiated within a spatiotemporally shifting and historically contingent political economy.

Christian Lund probes a case of forest and land conflict that is, at base, about struggles over authority and accountability. He considers the generative potential of an accountability lens when applied to questions of land governance that remain under-addressed in energy transitions scholarship. In his handling, authority is relationally and reflexively construed, through active and tacit contestations between competing actors. Rather than a state and non-state binary, governance here revolves around questions of claims to statehood and their recognition at multiple scales. Citizens seek to have their claims met by recognising the state at the more local village scale rather than a distant central government and, in doing so, try to reconfigure relations of power and authority. Power is unequally distributed, but its legitimation is necessarily contingent, and is what bestows an organisation with institutional authority to control resources in more persistent ways that can subdue resistance. In Lund's telling, this contingency is revealed as an opportunity for hitherto marginalised actors to not only vye over resources but to orchestrate a redefinition of where authority resides, and thereby of the state itself.

Håvard Haarstad examines the problematic of setting targets for carbon emission reduction at the urban scale both in general and specifically in Norway in terms of its pitfalls as well as potential. He first sets up a case for debunking urban climate and energy targets as the vanity projects of street-smart local politicians- the targets do not seem to be achievable and policies to realise them are not systematically deployed. Then he takes a step back to point out that the very act of target-setting has performative and discursive power, it imbues actors with the ability to point at a goal and orchestrate ambitious actions around it that might otherwise have 
failed to get off the ground. This normalising of mitigation targets in various forms at the urban scale, in Haarstad's rendering, enables energy transitions. It does so by establishing new accountability relations in a graduated manner that imbricates them within existing routines of decision-making and configurations of power. For strategies to legitimate carbon reduction, discretion may well be the better part of confrontation in shifting policy-making over vital domains to the urban scale for implementation in line with climate target creep.

Benjamin Sovacool bases his reflections on engagement with electric vehicle roll-out in the five Nordic countries, a region that is in the global lead on this energy infrastructure and mobility decarbonisation transition. Drawing on an impressive range of empirical material, this case highlights the many urgent reasons for a shift to electric mobility. It engages closely with the materiality and political economic dynamics of how this transition actually pans out in order to throw into relief how electric mobility alone can hardly address the problems it is commonly portrayed as resolving; these problems are deeply embedded within systems of mobility themselves. Sovacool flags unfolding accountability crises linked with inequitable access to electric vehicles, exclusionary and elitist planning, global externalities, and exacerbated social vulnerabilities. The chapter problematises the perpetuation of car-centric mobility alongside planning centred on public transport electrification and points to the perils and promises of how roll-out interfaces with electric grid flexibility and the integration of renewable energy sources. His treatment spans sectoral actors from national authorities to vehicle dealerships and from those affected by extraction to those buying Teslas, in keeping with an appreciation of accountability relations as multi-scalar, multi-sited, polycentric and amorphous in a sectoral layering of regimes.

Steven Wolf thinks through a case of dysfunctional habitat exchange markets around the sage-grouse in Colorado to interrogate the construction of hollow accountability. On the one hand, science-based assessment presents energy extractive industries with clear costs associated with oil and gas extraction activities so as to compensate for the displacement of this endangered species by provisioning for habitat replacement. Institutional orchestration creates the requisite paraphernalia around this, including actors to execute compensatory habitat exchange, a quantification tool and a market to facilitate these transactions. On the other hand, power trumps substantive assessment, as the extractive majors refuse to entertain the estimated costs and the habitat exchange fails to record a 
single transaction. Wolf argues that these developments are rightly understood as situated within accompanying changes at the federal and state levels pertaining to regulation and political dynamics. Rather than a case of abject failure, he reads it as the construction of requisite institutions to exercise accountability mechanisms that render energy extraction and biodiversity conservation not necessarily mutually exclusive, given political will and future enabling policy. This cross-sectoral analysis raises questions of legitimacy for the evolution of the energy sector in the American West, evidencing a lack of credibility to claims of energy transition.

After the five case chapters comes Part III, which comprises editorial reflections and a co-authored concluding synthesis. It takes a step back to revisit the cases at a higher level of abstraction. Chapter 9 draws out the various registers where practices of legitimation are at work in each case. Chapter 10 demonstrates application of the practices of legitimation within dimensions that are present in the five cases and highlights opportunities to cross-fertilise scholarship on energy transitions and environmental governance. Part III thus brings together openings in the fields that are broached by the case chapters and by the framing of the book. With this in mind, the reader is invited into the wide-ranging world of energy transitions over the course of Chaps. 4, 5, 6, 7 and 8 .

Open Access This chapter is licensed under the terms of the Creative Commons Attribution 4.0 International License (http://creativecommons.org/licenses/ by $/ 4.0 /$ ), which permits use, sharing, adaptation, distribution and reproduction in any medium or format, as long as you give appropriate credit to the original author(s) and the source, provide a link to the Creative Commons licence and indicate if changes were made.

The images or other third party material in this chapter are included in the chapter's Creative Commons licence, unless indicated otherwise in a credit line to the material. If material is not included in the chapter's Creative Commons licence and your intended use is not permitted by statutory regulation or exceeds the permitted use, you will need to obtain permission directly from the copyright holder.

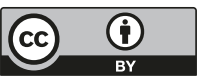




\title{
Historicising Accountability: Berlin’s Energy Transitions
}

Timothy Moss

\begin{abstract}
This chapter explores accountability and energy transitions through the lens of historical analysis. It reinterprets empirical research on the history of Berlin's energy systems to illustrate how accountability and legitimacy are political constructs of a particular time and place. Three periods of reconfiguration to urban electricity and gas networks, chosen from across Berlin's turbulent past century, illustrate this diversity. The chapter outlines each selected case and its pertinence to energy accountability. It then describes what crisis of accountability was prevalent in each instance and its treatment in the literature. The practices of legitimation enrolled to justify energy strategies are subsequently highlighted, as are forms of resistance and attempts to delegitimise the dominant discourse. The conclusion summarises the implications of historicising accountability for energy transitions research.
\end{abstract}

Keywords Accountability $\bullet$ Legitimacy $\bullet$ Berlin $\bullet$ Energy $\bullet$ History

T. Moss $(\bowtie)$

Integrative Research Institute on Transformations of Human-Environment Systems (IRI THESys), Humboldt University of Berlin, Berlin, Germany e-mail: timothy.moss@hu-berlin.de

(C) The Author(s) 2020

S. Sareen (ed.), Enabling Sustainable Energy Transitions, https://doi.org/10.1007/978-3-030-26891-6_4 


\subsection{What Is the Case and Why Is It an Energy Transitions Case?}

This chapter explores ways of contextualising accountability and accountability crises, both temporally and spatially. Using the case of Berlin over the past 100 years, it aspires to enrich debate on accountability in energy transitions - the focus of this book-by reflecting on historical precedents that can challenge some 'presentist' assumptions underpinning much of this work. Following the editor's invitation (Sareen 2019), I reframe ongoing and published research on Berlin's multiple energy transitions (Moss 2014, 2016; Becker et al. 2017) in terms of crises of accountability and practices of legitimation. In doing so, I hope to sensitise future research on this topic to the importance of time and space. The underlying question guiding the chapter is: how can historicising accountability contribute to our understanding of energy transitions and ways of researching them?

Berlin lends itself to such an analysis in part because accountability has, today, become a key issue of contention over the future of the city's energy infrastructures (Becker et al. 2015, 2017; Blanchet 2015). Over the past decade, criticism of the city's electricity and gas utilities, which were both fully privatised during the 1990s, has targeted not only their reluctance to embrace the low carbon agenda but also-significantly-their resistance to public scrutiny and the democratisation of decision-making processes. A local referendum to remunicipalise Berlin's electricity grid narrowly failed in November 2013, but the campaign generated two social movements. These have since managed to reframe energy policy debates in the city around issues of accountability, participation and transparency. The first is the Berlin Energy Roundtable (Berliner Energietisch), a coalition of approximately 50 environmental, leftist and anti-gentrification organisations that calls for a democratic, ecologically oriented and socially just 'citizens' utility'. The second is an energy cooperative, Citizen Energy Berlin (BürgerEnergie Berlin), that is at least partly owned by a collective of consumers. Pressure from both organisations has succeeded in changing the city government's policy, which in its current red-red-green complexion has established a small publicly owned energy utility in direct competition with the incumbent Vattenfall. This utility-Berlin Energie-is designed to be more accountable not only to local politicians but also to local energy consumers.

While restricting attention to this ongoing experiment in urban energy democracy would be revealing enough about how accountability is being 
framed and institutionalised today, it would say nothing about the historical context of energy accountability in the city. What makes Berlin interesting in this context are the different kinds of energy transition it has witnessed during its turbulent recent history. In the course of the past 100 years, Berlin has experienced political regimes of unparalleled range-from democratic to fascist to state-socialist- that each tried to mould urban energy policy in their own image. It is these multiple energy transitions, rather than the one, low carbon energy transition of today, which are the empirical focus of this chapter. The task is to compare the current with earlier phases of energy transition (in senso lato) in order to reveal how accountability has been variously invoked and what practices of legitimation have been enrolled to justify action.

The challenges of this venture are considerable. Apart from investigating energy transitions very different to the one pursued today, the societal norms framing both form and content of legitimacy (cf. Bäckstrand et al. 2018) underwent massive shifts during the course of the twentieth century. Accountability under National Socialism was not about the government serving the people, but the people serving Führer and Volk. In East Germany, the Socialist Unity Party established itself as the steward of the working class to which all citizens should pay obeisance. These extreme examples illustrate how much accountability and legitimacy are political constructs of their time, and indeed, of specific places. Although focusing on such undemocratic regimes could be instructive, this chapter instead selects examples of urban energy transitions drawn from Berlin's more democratically constituted governance systems, in order to generate findings of greater relevance to most contexts today. Three periods of transition have been chosen: (1) creating model municipal energy utilities for the new Greater Berlin in the 1920s, (2) sustaining energy autarky in an isolated West Berlin during the Cold War and (3) democratising urban energy governance in the city today. As argued later, they constitute cases of the politics of distribution, protection and representation, respectively.

\subsection{What Crises of Accountability Are Being Maintained or Challenged?}

The crisis of accountability in 1920s Berlin revolved around who should be responsible for supplying the burgeoning metropolitan area with public services, including electricity and gas. Prior to 1920, Berlin was geograph- 
ically minute, surrounded by powerful bourgeois-led municipalities that had successfully resisted amalgamation, thanks to the restrictive suffrage in Prussia. The large cities around Berlin each had their own energy utilities, which they zealously protected. The German revolution of 1918-1919 and the introduction of universal suffrage opened the floodgates for socialist schemes that were geared to substantiate the promise of democracy with more equitable and affordable public services for all. The creation of Greater Berlin in 1920 marked a milestone of this kind. Amalgamating seven cities, 59 smaller municipalities and 27 landed estates, the new Berlin grew 12 -fold in size. It incorporated all existing municipal energy companies into its own electricity and gas utilities (Bewag and Gasag), which were, henceforth, entrusted with implementing territorial unification by means of uniform service standards, tariffs and working conditions. To the new government of Greater Berlin, it was of critical importance to have a single utility accountable to a single city authority in the provision of power or gas services. Equally important was the provision of electricity and gas produced by the city's own utilities. This involved resisting persistent approaches by the major national energy providers of the day, Reichselektrowerke A.G. and Ruhrgas A.G., to supply the capital as part of their own programmes of territorial expansion and system centralisation (Fig. 4.1).

In West Berlin of the 1970s, a very different crisis of accountability emerged around the city's energy provision. Ever since the Berlin blockade of 1948/1949 and the subsequent political division of the city, West Berlin had sought to minimise dependence on East Germany and East Berlin by generating its own electricity and producing its own (town) gas. This strategy of urban energy autarky required a huge number of power and gas plants to be built within the city limits, but this was toleratedindeed, celebrated-by West Berlin residents throughout the 1950s and 1960s as a symbol of defiance of the 'insular city'. Decisions by the city's power utility to build ever more generating capacity were not questioned for fear of appearing to undermine West Berlin's very existence. By the 1970s, however, popular resistance to the serious environmental and public health hazards posed by continuous infrastructure expansionespecially to the city's air quality and ecosystems - was posing a massive threat to the compact of non-accountability between utility and citizen. The more the energy utilities insisted on the need for additional plants to keep West Berlin functioning, the more the protestors questioned the fun- 


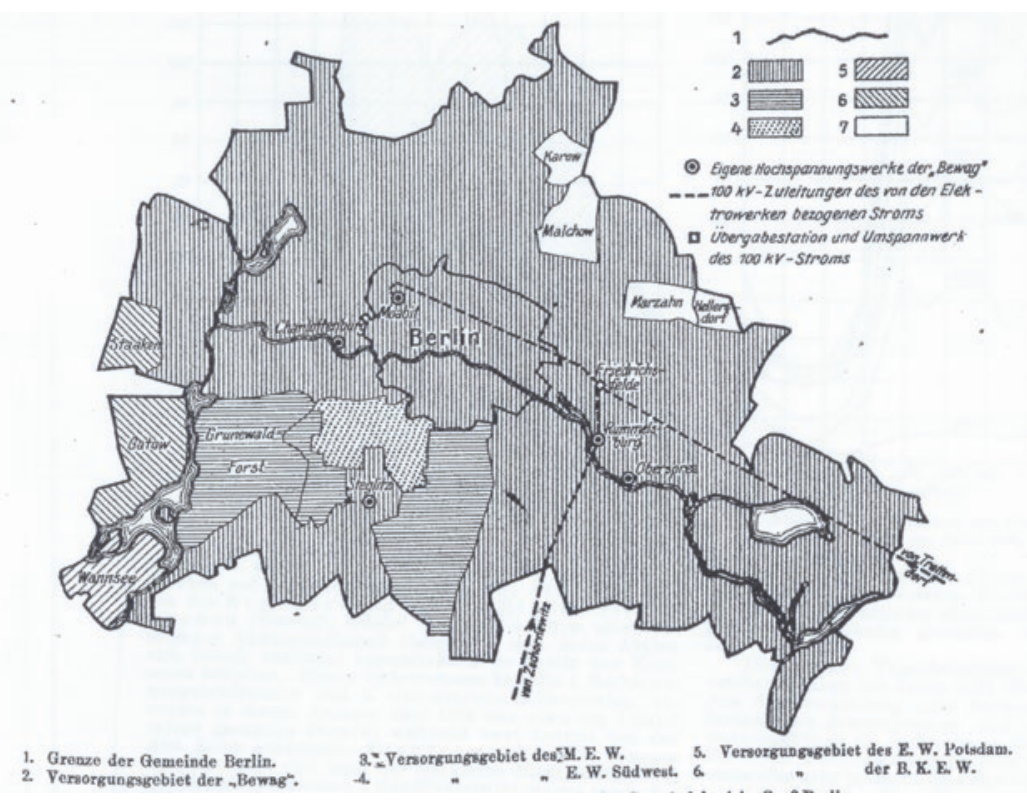

Fig. 4.1 Map showing size of Berlin prior to 1920 (marked core area) and territory of municipalised power utilities by 1925 (vertically striped area). (Source: Bruno Thierbach, 1925, Die gegenwärtige Versorgung der Stadt Berlin und der Provinz Brandenburg mit elektrischer Arbeit. Elektrotechnische Zeitschrift, 46(39), 1465)

damental assumptions on which the call for increased capacity was based. The issue came to a head in 1976-1977 over a decision by the city government and its power utility to build a new 600-Mega Watt power plant in the middle of one of the city's remaining forests. Massive protests and prolonged court cases resulted in the planned power plant being stopped, but not before it had been revealed to the public how both Bewag and the city government were prepared to ride roughshod over legal constraints and societal norms in order to achieve their common goal. Bewag's public image never really recovered from the damage this affront to public accountability caused amongst the population (Mielke and Weiß 1977). The case of the rejected power plant became a milestone of energy governance in Germany (Fig. 4.2). 


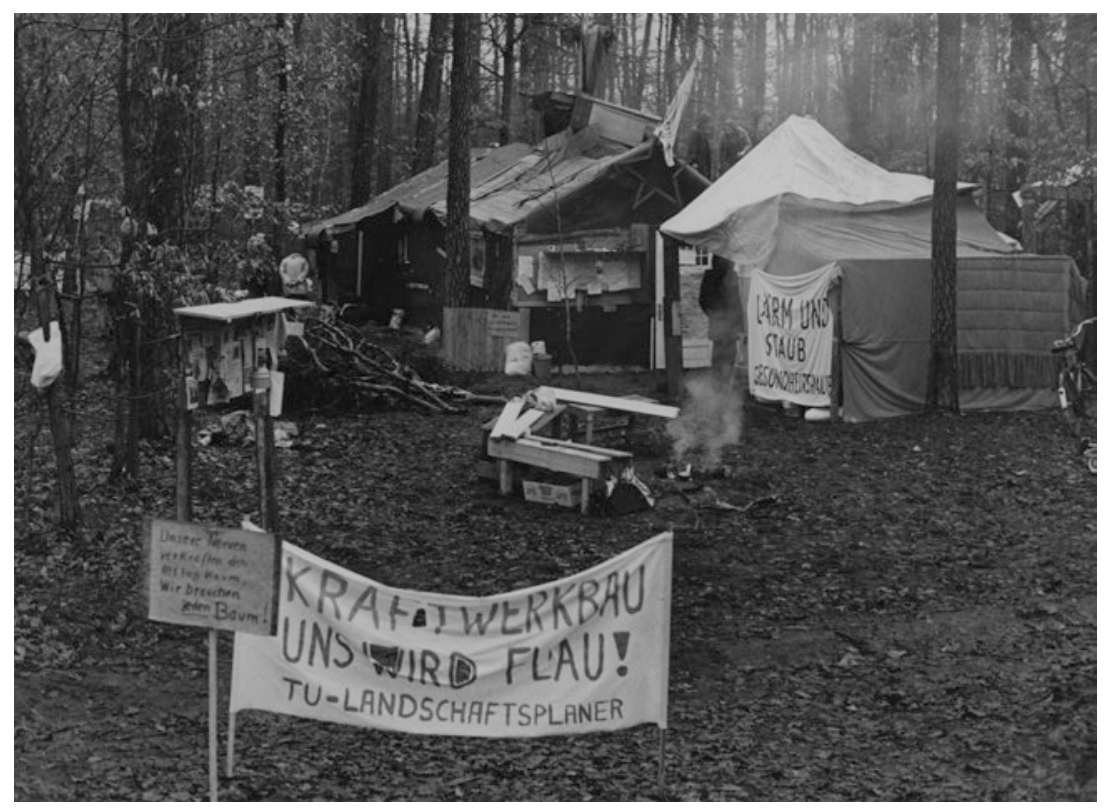

Fig. 4.2 Protest camp against the planned power plant in Spandau Forest, 1976. (Source: Landesarchiv Berlin, F Rep 290, No. 0194-662)

Today's accountability crisis revolves around the ownership and control of the city's energy systems. The renewal of the concession agreements for the electricity grid and gas network in 2014 provided a window of opportunity for the two grassroots initiatives-the Berlin Energy Roundtable and Citizen Energy Berlin-to challenge the position of the incumbent utilities: Vattenfall and Gasag. Whilst the Roundtable has campaigned for the city to take over the electricity concession in one form or another, the cooperative has sought to take it on itself in partnership with others. A very public contestation has emerged between Vattenfall and its opponents over the future of Berlin's power grid. Vattenfall has argued that only it possesses the experience and expertise necessary to run a complex electricity system. The civil society organisations have countered that only an accountable municipal utility can deliver on policy targets for renewable energy and decarbonisation. The dispute landed in the courts and was only resolved - in favour of the new municipal utility Berlin Energie-in March 2019 (Fig. 4.3). 
Fig. 4.3 Campaign poster of the Berlin Energy Roundtable for the 2013 referendum, reading 'Our municipal utility, our power grid, our Berlin'. (Source: http://www.berlinerenergietisch.net/ materialien)

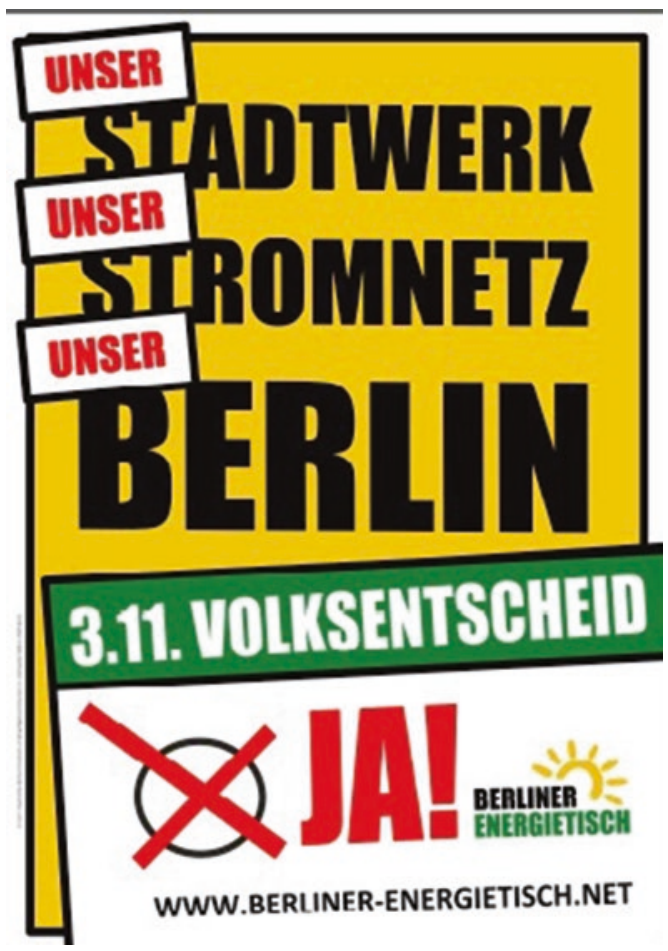

\subsection{How Do Environmental Governance Scholars Characterise the Case?}

The story of Berlin's energy policy in the 1920s has been told only by the author, and to date only from selective perspectives. These perspectives have highlighted interest in balancing electricity load curves with demand management measures (Moss 2014) and the rise and fall of alternative energy technologies in the interwar years (Moss 2016).

The impact of political division on West Berlin's energy infrastructures and utilities was analysed initially by the political scientist Richard Merritt in the 1960s, but not with respect to environmental issues (Merritt 1968). The author of this chapter has explored how division nurtured a strategy of spatial reorientation and self-dependence of energy provision around the insular city (Moss 2009) that largely failed to entertain options for saving energy or using it more efficiently (Moss 2014). 
By contrast, in Berlin today, there is considerable academic interest in initiatives to reform energy governance and reconfigure energy infrastructures (Becker et al. 2015, 2017; Blanchet 2015). What captivates these environmental governance scholars is the novel kind of collective control and accountability being advanced by the two social movements. Remunicipalisation, to these initiatives, means much more than returning a privatised utility to municipal ownership. It is about creating a wholly new kind of utility that is transparent to public scrutiny, open to joint decision-making by consumers and obliged by protocol to serve the public interest in keeping energy affordable and protecting the climate. This agenda is, as recent research reveals (Becker et al. 2015), broadening the scope of debate on energy governance in the city and undermining the previously unchallenged hegemony of the incumbent providers, notably Vattenfall.

\subsection{What Practices of Legitimation Appear to Be at Play in Empirical Work?}

In the 1920s, the core issue of legitimacy was creating uniform and affordable public services for the enlarged municipal entity of Greater Berlin. This had been the principal rationale for expanding the city's boundaries; after 1920, it needed to be put into practice. Municipal politicians never tired of emphasising the importance of the city's own energy (and water) utilities as instruments to this end. Practices enrolled to deliver the promise came in three forms: first, unitary tariffs across the territories of the newly united utilities (if not the whole city); second, uniform service standards for access, supply and maintenance; and third, fair and equal wages for employees across the city. These improvements to public services provided the justification for massive investments in urban infrastructure. The argument of uniform and fair services for Greater Berlin was mobilised repeatedly to rally local support for building state-of-the-art power stations (e.g., the Klingenberg plant) and experimenting with innovative technologies (e.g., heat storage for rapid power generation). The revenues generated from growing electricity sales, in particular, were used not only to fund these capital investments but also to support the beleaguered city budget, especially during the hyperinflation of 1922-1923 and depression during 1929-1933. The legitimacy of this policy of welfare expansionism did not go unchallenged. During the 1920s, the local Communist Party (KPD) criticised rising tariffs for hitting the poor hardest. Far more serious 
was the campaign launched by the Reichsbank President Hjalmar Schacht against the foreign loans used to fund much of Berlin's new energy infrastructure. By 1931, this culminated in the forced sale of most of the city's shares in Bewag to national and international energy conglomerates as a stop-gap measure to reduce the city's burgeoning debt.

In West Berlin during the Cold War, security was the overriding argument used to legitimise urban energy policy. Successive city governments and utility directors proclaimed, when any network expansion was planned, that failing to act would jeopardise the local economy and undermine West Berlin's capacity to provide its own electricity and gas. With the backing of the three Western Allied powers, high security standards were built into West Berlin's energy systems. These were epitomised by two core practices: first, storing sufficient reserves of primary energy (coal and oil) to power the city for at least three months and, second, creating a cascade of generating capacity capable of avoiding power outages even in the event that the largest generating block failed. The massive capital investments required for this security-oriented strategy did not need legitimising locally as they were heavily subsidised by the West German government. It was only in the 1970s, when fresh expansionist plans confronted an emergent environmentalist movement, that these practices of legitimation for West Berlin as an 'electricity island' were challenged seriously. For the first time, alternative models for energy provision in West Berlin were advanced by academics, activists and consultants. These revolved around reducing the need for new generating plant by promoting energy saving, using energy more efficiently (e.g., with small-scale co-generation), and, latterly, importing electricity from East German power plants upgraded with West German technology. These measures were deliberately framed to delegitimise the dominant narrative of build-and-supply.

The current conflict over Berlin's energy future is characterised by competing claims to legitimacy. On the one hand, the incumbent energy utilities (primarily Vattenfall, but also Gasag) present themselves to the public as the experts who, by virtue of their long-standing experience in running Berlin's energy systems, are the sole actors capable of managing the power grid and gas network. Technical expertise, track record and financial viability are the arguments they mobilise to justify their claims and belittle their competitors. On the other hand, the social movements campaigning for their kind of accountable remunicipalisation argue that it is precisely this reliance on traditional management criteria that is blocking attempts in the city to reduce energy use, cut carbon emissions and promote renew- 
able sources of energy. They are advancing a very different logic of legitimacy which targets global sustainability and local accountability. Significantly, they have managed to induce a shift in city government policy, from supporting the incumbent utilities to embracing a new municipal utility and a strategy of decarbonising the city's energy systems.

\subsection{What Interventions Could Enable Sustainable Outcomes Under Transition?}

Assessing historical examples in terms of sustainability norms is highly problematic, since sustainability—as currently understood-was not then an issue. Past interventions to reconfigure urban energy systems were made in the name of other overarching principles prevalent at the time, such as social equality or political security. What this brief foray into the past has revealed is, first, that crises of accountability over energy are not new. They have accompanied the emergence, consolidation and adaptation of energy systems since their early beginnings. Second, we have illustrated that what accountability can mean, how it is invoked, to what ends and through what mechanisms varies hugely according to particular contexts of time and space. What passes without arousing public disapproval in one context can be highly controversial in another. This prompts us to pause and reflect, when recommending practices of legitimation or modes of accountability governance, on what temporality might mean for their shelf-life and future-proofing. Today's accountability fix should not become tomorrow's accountability trap (Kramarz and Park 2017). Finally, the examples drawn from Berlin's history have shown how processes of legitimising energy transitions are inextricably bound up in much wider societal concerns, such as-in our three cases-the politics of distribution, protection and representation. Efforts to institutionalise sustainable energy transitions would, it follows, be well advised to heed, enrol or resist concurrent movements that are likely to influence-one way or another-the viability of a particular preferred pathway (Bouzarovski and Haarstad 2018).

\section{REFERENCES}

Bäckstrand, K., Zelli, F., \& Schleifer, P. (2018). The legitimacy and accountability in polycentric climate governance. In A. Jordan, D. Huitema, H. van Asselt, \& K. J. Forster (Eds.), Governing climate change: Polycentricity in action (pp. 338356). Cambridge: Cambridge University Press. 
Becker, S., Beveridge, R., \& Naumann, M. (2015). Reconfiguring energy provision in Berlin. Commoning between compromise and contestation. In M. Dellenbaugh, M. Kip, M. Bieniok, A. K. Müller, \& M. Schwegmann (Eds.), Urban commons. Moving beyond state and market (pp. 196-213). Basel: Birkhäuser.

Becker, S., Naumann, M., \& Moss, T. (2017). Between coproduction and commons: Understanding initiatives to reclaim urban energy provision in Berlin and Hamburg. Urban Research and Practice, 10(1), 63-85.

Blanchet, T. (2015). Struggle over energy transition in Berlin: How do grassroots initiatives affect local energy policy-making? Energy Policy, 78, 246-254.

Bouzarovski, S., \& Haarstad, H. (2018). Rescaling low-carbon transformations: Towards a relational ontology. Transactions of the Institute of British Geographers. https://doi.org/10.1111/tran.12275

Kramarz, T., \& Park, S. (2017). Introduction: The politics of environmental accountability. Review of Policy Research, 34(1), 1-4.

Merritt, R. L. (1968). Political division and municipal services in postwar Berlin. In J. D. Montgomery \& A. O. Hirschman (Eds.), Public policy (pp. 165-198). Cambridge, MA: Harvard University Press.

Mielke, H.-J., \& Weiß, H. (1977). Kraftwerksbau im Landschaftsschutzgebiet Spandauer Forst. Berliner Naturschutzblätter, 21(60/61), 251-255, 286-288.

Moss, T. (2009). Divided city, divided infrastructures: Securing energy and water services in postwar Berlin. Journal of Urban History, 35(7), 923-942.

Moss, T. (2014). Socio-technical change and the politics of urban infrastructure: Managing energy in Berlin between dictatorship and democracy. Urban Studies, $51(7), 1432-1448$.

Moss, T. (2016). Discarded surrogates, modified traditions, welcome complements: The chequered careers of alternative technologies in Berlin's infrastructure systems. Social Studies of Science, 46(4), 559-582.

Sareen, S. (2019). Five easy pieces: Legitimation at work in cases related to energy transitions. In Enabling sustainable energy transitions: Practices of legitimation and accountable governance. London: Palgrave Macmillan. 
Open Access This chapter is licensed under the terms of the Creative Commons Attribution 4.0 International License (http://creativecommons.org/licenses/ by $/ 4.0 /$ ), which permits use, sharing, adaptation, distribution and reproduction in any medium or format, as long as you give appropriate credit to the original author(s) and the source, provide a link to the Creative Commons licence and indicate if changes were made.

The images or other third party material in this chapter are included in the chapter's Creative Commons licence, unless indicated otherwise in a credit line to the material. If material is not included in the chapter's Creative Commons licence and your intended use is not permitted by statutory regulation or exceeds the permitted use, you will need to obtain permission directly from the copyright holder.

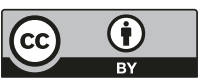




\title{
A Few Reflections on Accountability
}

\author{
Christian Lund
}

\begin{abstract}
Accountability is a form of communication between people and institutions where one is held to account by the other. Parts of the scholarship distinguish between upward and downward accountability. Upward accountability would involve acknowledgement of an authority to sanction or validate operations or claims, whereas downward accountability refers to the institution of authority being responsible to the general public for their actions. While the directionality of accountability is important, a case from Indonesia suggests that they may indeed be coconstitutive. By deliberately and publicly complying with the idea of state land ownership, and by being selective about what institutions represent 'the state', the farmers used their upward accountability to produce downward accountability in terms of recognition of their rights. The farmers exploited the separation of powers in their attempt to gain a new visibility.
\end{abstract}

Keywords Accountability $\bullet$ Recognition $\bullet$ Social contract $\bullet$ Indonesia

C. Lund $(\bowtie)$

Department of Food and Resource Economics, University of Copenhagen, Copenhagen, Denmark

e-mail: clund@ifro.ku.dk

(C) The Author(s) 2020

S. Sareen (ed.), Enabling Sustainable Energy Transitions, https://doi.org/10.1007/978-3-030-26891-6_5 


\section{Akk ja, retten, retten; hva hjelper det at du har retten når du ikke har noen makt? \\ [Ah yes, rights, rights; what does it help that you have rights when you do not have any power?] \\ —Fru Stockmann in "En Folkefiende" (Henrik Ibsen 1882)}

\subsection{Accountability and Social Contract}

'Everyone realizes how praiseworthy it is for a prince to honour his word and to be straightforward rather than crafty in his dealings; nonetheless contemporary experience shows that princes who have achieved great things have been those who have given their words lightly, who have known how to trick men with their cunning, and who, in the end, have overcome those abiding by honest principles. ... There are two ways of fighting: by law or by force. The first way is natural to men, and the second to beasts. ... a prince must know how to act according to the nature of both, ... he cannot survive otherwise' (Machiavelli 1961: 99). The candour of this sixteenth-century Secretary and Second Chancellor to the Florentine Republic is refreshing. Moreover, his book is probably among the most concise of the 30,000+ offerings from Amazon.com when you punch in 'accountability'. Google.com suggests a menu of 128,000,000 items in less than 0.3 seconds. Power's interest in power is obvious and unabashedly stated as a fact by Machiavelli. It is not cloaked in bureaucratic niceties and unrealistic assumptions about the common good, and as a self-help book for politicians, The Prince remains unsurpassed.

The principle of power stands in tension with the principles of its division. Montesquieu's idea about the separation of powers (1977), Locke's suggestion to rein in tyranny (1980) and Rousseau's doctrine that government must rest on a social contract (1977) all recognise the truths of the drive for power described by Machiavelli, and they all share a concern for the danger of power's concentration. Each, in their own way, suggests checks and balances in the system of government, and within the European history of enlightenment, they may be the first to articulate concern with power's accountability. While Montesquieu focuses on the mutual accountability among institutions of power, Locke and Rousseau direct their attention to the relationship between the governors and the governed. In a nutshell, Rousseau argues that government (or the sovereign) derives its legitimacy to govern from the power freely surrendered by the 
governed in a social contract where the government is elected by the people as a representation of the general will and is therefore accountable to it. The social contract rests on an understanding of mutual recognition between state and citizenry when the population is subject to the laws of the state, and the state is subject to popular political franchise. This figure, however, is as abstract as it is beautiful.

In actual societies, and maybe especially in post-colonial societies, the number of institutions that operate in the name of the state approaches the infinite, and citizenship itself is fraught with intersecting qualifications derived from gender, race and caste, as well as class, creed and conviction (Lund 2016). In terms of social contract, this raises the question: as what are the contractual partners recognised? Who is visible to what institution, and what institution commands authority in what domain? A way to access the empirical complexity may be on offer from a broad philosophical tradition that takes recognition as a fundamental human expression of acknowledgement of the 'other' (Arendt 1973; Fraser 2001; Honneth 1996; Taylor 1989, 1994). Honneth, in particular, talks about visibility among and between actors, and I believe it can be extended to institutions. Social contracts of recognition require mutual visibility between actors and institutions. Actors must have a social, legal, fiscal or cultural presence visible and acknowledged by an institution, and the institution must legitimately appear capable of providing the desired recognition of a claim (Weber 1958). What actors are therefore comprises not individual features but relational, politically visible attributes. So, who is the actor? A tax payer, a peasant, or a red troublemaker, an indigene, a businessman, or a person without paper? And who defines the categories? And, similarly, we must ask what is the specific institution? Executive, legislative or judiciary, or can it be re-purposed to fit the task at hand?

This may seem a somewhat grandiose introduction to what is often seen as a governance routine question. I, however, suggest that any granular analysis of relations of accountability (Latour 2009; Strathern 2000) could do worse than to focus on power, its separation, the mutual recognition of claims and authority, and the representation of rights subjects (or citizens) and government. In the following, I present a summary case from my work in Indonesia to illustrate relations of mutual recognition (Lund 2020). While the case itself relates only indirectly to energy transitions, it surfaces concerns of conflict over land and forest that are germane to any discussion of energy transitions, not least given Indonesia's participation in a global carbon forestry programme (cf. Hein 2018). 


\subsection{Visibility AND ReCOGNITION IN INDONESIA}

Harumandala is a village in West Java in Indonesia. The village consists of several sub-villages or kampungs and is located within a steeply sloped landscape. After independence in 1945, the area saw many confrontations over land control between the Indonesian army and Communist groupings. The confrontations died down around 1961. The area was formally under the territorial authority of the Provincial Forestry Service of West Java, and the entire area was classified as 'forest'. However, most of the area was, in fact, populated with villages and kampungs. Generally, people were farming paddy rice on terraces, as well as different crops on forest plots. In practice, people could clear land for paddy rice farming and other activities without much interference from the authorities. No legal rights ensured people's access to land, but the Provincial Forestry Service tolerated farming and people regarded the land as their own.

In 1978, all the forestland controlled by the Provincial Forestry Service in West Java-close to a million hectares-was transferred to the State Forestry Corporation which had previously operated only in Central and East Java (Peluso 1992; Rachman 2011). As a parastatal institution with its own uniformed 'forest police', and as a part of an authoritarian regime, the State Forest Corporation was inaccessible to ordinary people seeking to argue or negotiate their case. The Corporation established boundaries to create teak and mahogany plantations, clearing the area of any farmed fields that might be in the way. Moreover, it started to act as a landlord charging rent for the fields people cultivated within the area. These farmers thus became tenants of the Corporation, and in the process consolidated its land control. The rent consisted of 33 per cent of the villagers' rice production: There was no legal basis for this rent, and it was never registered as official income of the company.

During the late 1990s, agrarian protest became ever more frequent as the Suharto regime spiralled into decline and crisis. Different social organisations, groups and movements were formed in a period of political transformation in Indonesia. Democratisation and decentralisation appeared to offer opportunities to transform society, and not least the agrarian structures. The protests were accompanied by land occupations, where farmers seized land from state forests or private and government plantations. The occupations were controversial. On the one hand, they were condoned and even hailed by popular movements as the realisation of the longawaited land reform. On the other hand, government condemned occupations as theft (Lucas and Warren 2013). 
In 2006, farmers and their organisation, Sundanese Peasant's Movement (Serikat Petani Pasundan [SPP]) realised that the Forest Corporation's collection of rent was illegal, and actions towards land reform could be launched. The first move was to refuse to pay rent to the State Forest Corporation. Instead, people paid 10,000 Rupiah (equivalent to a couple of US dollars) per month to SPP and turned their presence into a land occupation.

The West Java police commander and the Corporation director in Jakarta decided to re-establish the Corporation's control over the occupied forestlands by launching a so-called forest security operation funded by the Ministry of Forestry. The operation was preceded by a joint reconnaissance for forest security control conducted in March 2008. The State Forest Corporation provided the reconnaissance team with a detailed map that indicated 'forest security disturbances'. The team reported that approximately 290 hectares of forestland were occupied by nearly 1600 villagers from four villages within the district.

Three months after this reconnaissance report was issued, the West Java Police, the Ministry of Forestry and the State Forest Corporation launched a forest security operation. The main objectives of the operation were to re-establish control of the state forestland and to evict the people occupying it. The operation invoked the military terms, Security Operation and Dangerous Area, echoing the Suharto era. Similarly, the use of terms like 'illegal loggers', 'illegal occupiers', 'subversive' and 'anti-state' established an association between land occupation and organised crime. For a country the size of Indonesia, 290 hectares may seem trivial, but the significance of a successful occupation could be earth-shattering, literally breaking new ground for further challenges to state authority.

Officers from the State Forest Corporation and the Provincial Police came to Harumandala and its six kampungs, and more than 300 police officers set up camp and began to prepare the evictions. The operation was initiated by a ceremony, in which the police commander, the head of the Corporation's forest police and representatives from the local government Forestry and Plantation Unit went through the objectives of the operation-namely, to find evidence of illegal logging, to evict illegal occupants and destroy their farms and to remove any illegal construction from the area. First, the police and the Corporation officers made house-to-house searches for timber. Then, fields were ravaged and houses were burnt to the ground. Some houses were left standing, but the police marked them with chalk 'This house must be destroyed by yourself', or 'This house and 
land is not yours but the property of the state'. Finally, the police forced the villagers to sign a statement in which they renounced their membership of SPP and declared they would never join again. It is well worth recalling that this took place almost a decade into the post-New Order democratic era, and that SPP was a legal organisation.

After the police operation, people resumed the cultivation of their plots within the area but moved to kampungs outside of the State Forest Corporation area for a couple of years. By 2010, people had begun to move back to the abandoned kampung of Pasir Pilar within the Corporation-controlled area. People reconstructed their houses; and within six months, some 34 families had re-established themselves in the kampung. The local SPP chapter drew up a map of the area, registering each plot and its owner.

The State Forest Corporation contacted the settlement, but now with a new approach. They announced a planting ceremony of mahogany trees and invited villagers to witness. An area was cleared and 1000 seedlings were planted in rows. Each row was publicly named after a government institution. Thus, the first row was named, 'the row of the provincial governor', the next, 'the row of the police commander', 'the row of the Indonesian army' and so on. The intention, no doubt, was to impress upon the people of the area that these resources belonged to and were under the protection of the entire government structure of Indonesia. The State Forest Corporation had the whole episode filmed. The following night, however, all 1000 mahogany seedlings were uprooted. People remained in their kampungs on the disputed land; they resumed farming their plots and rice fields, and they continued not to pay rent to the State Forest Corporation. They were not beholden to the Corporation or the Indonesian government for their land rights. Instead, they held land thanks to 'the republic' of SPP, with the opportunities and dangers this implied.

As people moved back into their settlement, they asked the official local territorial administration - the village office-for new ID cards that would reflect this change. This was done. By that token, the settlement became an official kampung, situated within the area that the State Forest Corporation claimed to control as forest. Moreover, as people registered to vote for the 2014 elections, officials from the sub-district would visit all houses and place an official government sticker on the door with the name of the voter, and place of residence-their new official kampung. 
The system of payment to SPP remained provisory, but with the smallholders' return to the contested lands in 2010, all kampungs of Harumandala also began to contribute to the Village Office to the tune of 1,000,000 Rupiah annually. At first, the Village Office, its mayor and its elected parliamentarians were reluctant to receive the funds. They were unsure whether they were entitled to recover tax, and what it would mean to accept it, but after some negotiation the Village Government of Harumandala accepted the money at a public ceremony. While still perceived as illegal occupants by the State Forest Corporation, smallholders were also beginning to be seen as taxpaying, voting, registered, Indonesian citizens. Their 'contribution', or tax, established a new substantive relationship between them as landholders and the formal structures of the Indonesian government at its lowest level, the Village Office. It remains to be seen what this new relationship represents. One might argue that this relationship not only established the SPP landholders as owners of property in the eyes of the Village Office; it also established the Village Office as a public authority on questions of property in land that was classified as forest. As the smallholders made claims to resources, they also invoked public authority in the Village Office. Tax collection attributed to it governing capacity and the authority to validate land claims. This may, eventually, put the Village Office in competition with other statutory institutions.

\subsection{REFLECTIONS}

Accountability is a form of communication between people and institutions where one is held to account by the other. Parts of the scholarship distinguish between upward and downward accountability (Fox 2018). Upward accountability would involve acknowledgement of an authority to sanction or validate operations or claims, whereas downward accountability refers to the institution of authority being responsible to the general public for their actions. While the directionality of accountability is important, the case from Indonesia suggests that they may indeed be coconstitutive. When the villagers shifted from payment of rent as tenants to one part of government (the Corporation), to payment of a community tax to another part of government (the lowest level assembly and government), they not only morphed from undercover tenants to enfranchised citizens, but also invoked capacities in the village government that it had not had before. By deliberately and publicly complying with the idea of 
state land ownership, and by being selective about what institutions represent 'the state', the farmers used their upward accountability to produce downward accountability in terms of recognition of their rights. The farmers exploited the separation (or multi-location) of powers in their attempt to gain a new visibility.

The power to define subjectivity - to define it for oneself or to impose it on others - is essential in any relation of accountability, because it defines actors' visibility and, consequently, the possible fields of engagement and contracts of recognition. The Ministry of Forestry and the State Forest Corporation had been long established as the consequential authorities holding the power to define who is entitled and who is a thief. Yet, the active re-orientation by the farmers re-drew the map of mutual recognition. To be sure, this relied on people's capacity and political space to recast themselves as responsible citizens and rights subjects rather than passively being defined as subversive squatters and enemies of the state.

Actors have different capacities to engage in the field of politics. However, the field itself is a result of engagement, not only by the powerful but also by those who resist and want change. This desire for changeexpressed through local politics of land-may, in E.P. Thompson's words (1963: 12), be foolhardy. But the desire for change defines agency and is hardly inconsequential for the relations between people and institutions.

\section{REFERENCES}

Arendt, H. (1973 [1951]). The origins of totalitarianism. New York: Harcourt Brace Janovich.

Fox, J. (2018). The political construction of accountability keywords. IDS Bulletin, $49(2), 65-80$.

Fraser, N. (2001). Recognition without ethics? Theory, Culture and Society, $18(2-3), 21-42$.

Hein, J. I. (2018). Political ecology of REDD+ in Indonesia: Agrarian conflicts and forest carbon. Abingdon and New York: Routledge.

Honneth, A. (1996). The struggle for recognition. The moral grammar of social conflict. Cambridge: Polity Press.

Ibsen, H. (1882). En Folkefiende [An Enemy of the People]. Oslo: Gyldendal.

Latour, B. (2009). The making of law: An ethnography of the Conseil d'Etat. Cambridge: Polity.

Locke, J. (1980 [1689]). Two treatises of government. Cambridge: Cambridge University Press. 
Lucas, A., \& Warren, C. (Eds.). (2013). Land for the people: The state and Agrarian conflict in Indonesia. Columbus, OH: Ohio University Press.

Lund, C. (2016). Rule and rupture. State formation through the production of property and citizenship. Development and Change, 47(6), 1199-1228.

Lund, C. (2020). Nine-tenths of the law. Enduring dispossession in Indonesia. New Haven, Yale University Press.

Machiavelli, N. (1961 [ca. 1532]). The Prince. London: Penguin.

Montesquieu, C.-L. (1977 [1748]). The spirit of the laws. Berkeley: University of California Press.

Peluso, N. L. (1992). Rich forests, poor people. Resource control and resistance in Java. Berkeley: University of California Press.

Rachman, N. F. (2011). The resurgence of land reform policy and Agrarian movements in Indonesia. PhD thesis, University of California, Berkeley.

Rousseau, J.-J. (1977 [1762]). Du contrat social. Paris: Éditions du Seuil.

Strathern, M. (2000). Audit cultures. Anthropological studies in accountability, ethics and the academy. London: Routledge.

Taylor, C. (1989). Sources of the self. The making of modern identity. Cambridge: Cambridge University Press.

Taylor, C. (1994). The politics of recognition. In A. Gutmann (Ed.), Multiculturalism (pp. 107-148). Princeton, NJ: Princeton University Press.

Thompson, E. P. (1963). The making of the English working class. London: Penguin.

Weber, M. (1958). From Max Weber. Essays in sociology (H. Gerth \& C. W. Mills, Eds.). New York: Oxford University Press. 
Open Access This chapter is licensed under the terms of the Creative Commons Attribution 4.0 International License (http://creativecommons.org/licenses/ by $/ 4.0 /$ ), which permits use, sharing, adaptation, distribution and reproduction in any medium or format, as long as you give appropriate credit to the original author(s) and the source, provide a link to the Creative Commons licence and indicate if changes were made.

The images or other third party material in this chapter are included in the chapter's Creative Commons licence, unless indicated otherwise in a credit line to the material. If material is not included in the chapter's Creative Commons licence and your intended use is not permitted by statutory regulation or exceeds the permitted use, you will need to obtain permission directly from the copyright holder.

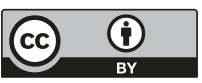




\title{
Do Climate Targets Matter? The Accountability of Target-setting in Urban Climate and Energy Policy
}

\author{
Håvard Haarstad
}

\begin{abstract}
Climate-related targets abound, but are they important drivers of policy action? Given the apparent gap between ambitious targets and concrete actions to reach them, climate-related targets can easily be seen as representative of a crisis of accountability. At the same time, this chapter argues, there are practices of legitimation at work that can help overcome this crisis, and translate abstract and arbitrary targets into concrete policy implementation. Norway's Zero Growth Objective in transport policy represents a case of this. From its first formulation as a target around 2006 and until 2019, it has materialised as a "hard" target shaping funding streams and concrete policy interventions, and most likely, emission levels. Under certain conditions, abstract targets play important roles in legitimating transition policy.
\end{abstract}

Keywords Climate targets $\bullet$ Metrics $\bullet$ Implementation $\bullet$ Transport $\bullet$ Accountability

H. Haarstad $(\bowtie)$

Department of Geography, Centre for Climate and Energy Transformation, University of Bergen, Bergen, Norway

e-mail: Havard.Haarstad@uib.no

(C) The Author(s) 2020

S. Sareen (ed.), Enabling Sustainable Energy Transitions, https://doi.org/10.1007/978-3-030-26891-6_6 


\subsection{INTRODUCTION}

A casual observer of the official fight against climate change may get the impression that it is primarily about setting quantitative targets for emissions reduction. Who has committed to the $2{ }^{\circ} \mathrm{C}$ target? How did the world's leaders discuss the $1.5{ }^{\circ} \mathrm{C}$ target at the latest high-level meeting? Who has the most ambitious target for cuts in $\mathrm{CO}_{2}$-emissions, or for growth of renewables? It may seem that setting targets is what climate policy consists of.

Cities have certainly entered this game. Since the city council of Freiburg in 1996 decided to cut $25 \%$ of its $\mathrm{CO}_{2}$-emissions by 2010 (Leal and Azevedo 2016), cities all over the world have set ambitious and celebrated targets for a range of climate-related challenges such as emission cuts, renewable energy use, energy efficiency, electric vehicle uptake and growth of bicycle use and infrastructure. More than 7700 local and regional authorities have signed up to the Covenant of Mayors and thereby committed themselves to achieving and exceeding the EU climate and energy targets. The Covenant of Mayors initiative is one of many examples of how governance entities are organising themselves in networks rallying around particular targets.

The key question is, of course, what all this targeting and goal-setting means for actual climate policy. From a bird's-eye view of urban climate policy, it is tempting to conclude that these targets are not followed by policies that may realistically ensure that they are met.

It is not that cities are ignoring the climate challenge-on the contrary, many commentators view cities as leading the fight against climate change (Rosenzweig et al. 2010). Yet, considering the drastic transformations that many of these targets involve-for example, 72 cities have committed to the C40 network's Deadline 2020 programme of cutting $\mathrm{CO}_{2}$ emissions in line with the Paris Agreement-one might suspect that the current practices of target-setting are unconnected to any realistic programme of delivering on what they promise. It would follow that the ambitious target-setting are exercises of vanity, wherein cities compete for the most ambitious targets but not the most transformative policies. And thereby that targets help politicians appear to be doing something when they are actually not. In this sense, we are faced with a crisis of accountability in which politicians can capitalise on climate-sensitive rhetoric but escape being held to account for that same rhetoric. 
At the same time, the question of what all this targeting and goalsetting means for actual climate policy may also generate a different set of answers. What if target-setting is more important and substantive than it looks? Even if not all the rhetoric is translated into substantive policy, could there be ways in which target-setting actually percolates into substantive policy-making practices?

This chapter reflects on the nature of target-setting, focusing in particular on climate and energy policy in cities. I recognise that target-setting is a political-rhetorical practice, and therefore not necessarily representative of actual processes of transformation-we should expect a lot of hot air. But I aim to go beyond the readily-at-hand analysis that suggests targets are simply vanity exercises without practical implications, and to look deeper at the ways in which target-setting may in fact "trickle" up and down in governance systems and-in a gradual way-facilitate transitions.

\subsection{Climate Governance as Political-Rhetorical Practice}

Scholars have often taken a sceptical view of official climate discourses, including their ambitious targets. It is common to see this discourse as evading or purposely obfuscating the conflicts of interest and difficult choices involved in meeting the climate challenge. Swyngedouw (2010), for example, holds that the policy discourse on climate change is characteristic of the "post-political condition." He has argued that reduction of $\mathrm{CO}_{2}$ emissions is inserted into a vast techno-managerial apparatus, "ranging from new eco-technologies of a variety of kinds to unruly complex managerial and institutional configurations, with a view to producing a socio-ecological fix to make sure nothing really changes" (p. 220, italics mine).

In other words, instead of addressing the underlying substantive political challenges, conflicts of interests and difficult trade-offs of climatefriendly transformation, official climate discourse manages to produce a set of interventions that harmonise with economic growth, the fossil economy, and so on, thus perpetuating business-as-usual practices. This is why climate governance is, in the words of Methmann, an "empty signifier"it serves to integrate climate protection into the global hegemonic order "without changing the basic social structures of the world economy" (Methmann 2010: 348). Hegemonic governmental agents have been able 
to remake almost any policy-free trade, continued oil exploration, economic growth-into being part of the solution.

A similar critique has been levelled against the entire sustainable development discourse, in a debate too vast to enter into here (but see While et al. 2010).

At the urban scale, these trade-offs and conflicts of interests may be harder to conceal. Yet even here, scholars have pointed to the contrast between rhetorical aspects of governance and substantive transformative interventions. In terms of rhetoric, cities generate and circulate highprofile stories and "best practice" narratives that highlight claims about achievements and successes (Bulkeley 2006; McCann 2011). In terms of substantive change, however, real effects may be more elusive. Grandin and Sareen (forthcoming) describe urban governance arrangements as "often characterised by voluntary action, weak institutions, non-binding commitments and uncoordinated efforts," and argue that it can be difficult to determine the substantive and enduring transformative impact of their interventions.

More concretely, researchers have also criticised the targets that cities are operating with. Leal and Azevedo (2016) reviewed the targets for local energy planning for a number of case cities, and found them to show a lack of standardisation of methodologies, "leading to a diversity that may not only hamper the comparison between different municipalities' action but also prevent a consistent assessment of their global impact." In similar vein, Kramers et al. (2013) found a wide variety of accounting methodologies, system boundaries, time frames and source of emissions included behind relatively similar targets. There is moreover limited awareness of these methodological limitations among city administrators.

In short, one can find grounds for deep scepticism against the practice of target-setting in the climate governance literature. In an abstract sense, these targets are often part of a post-political and techno-managerial climate governance discourse that simultaneously appears climate-friendly without addressing the underlying contradictions that produce the climate problem in the first place. At the urban level, target-setting can be seen as a part of the circulation of "best practice" and rhetorical competition to be the most sustainable city, while the actual commitments remain largely non-binding and voluntary.

In this sense, target-setting registers on several of the types of legitimation Sareen outlines in Chap. 2 of this book, but perhaps particularly discursive legitimation. These are legitimation practices that normalise 
particular ways of seeing, stabilising them in the public imaginary. In the worst-case scenario, targets are stabilising the idea that our decisionmakers are tackling the climate challenge in an ambitious way, while actually, very little gets done.

However, what if we put aside the worst-case scenario for a moment, and consider the flip side of the coin? Is it possible that targets, even seemingly overly ambitious ones, may have real and substantive effects that contribute to a sustainable transition? Could there be mechanisms through which targets - even unrealistic ones-influence, push or nudge urban politics and processes of change? This is not to cast aside the critical perspectives outlined above, but to suggest that analogous mechanisms of legitimation may also work in the opposite direction.

\subsection{Metrics That Can Legitimate the Sustainability Transition}

My starting point for thinking about ways targets may legitimate transitions is to consider the carrying power of numbers (or "metrics"). It is widely recognised that quantifying a phenomenon impregnates it with a particular type of force, transforming it from the particular and provincial into the language of the universal. Foucault, for instance, showed how scientific knowledge - where metrics play a central role-is the foundation for the birth of the modern state (Foucault 1991). Metrics is what we use to make the unknown knowable, and thereby, governable. Foucault's work showed how scientific knowledge advanced our ability to govern society and its individuals. Now, we are progressively using scientific knowledge to govern nature as well. As Jasanoff (2010) puts it, "Increasingly, however, the politics of nature occurs under the rubric of 'environment'-a domain of ideas and entities accessible only with the aid of science and technology."

In this sense, it is quite conceivable that climate targets take on a similar type of carrying power as other metrics have done in our governance of nature. Climate change is knowable and measurable in precise ways, through global aggregate temperatures traced far back in time, parts per million of $\mathrm{CO}_{2}$ in the atmosphere, and carbon budgets, among many others. Measures to deal with climate change are also knowable and measurable in detailed ways, through percentage of rise in renewable energy uptake, energy efficiency measures, numbers of electric vehicles sold and 
so on. This means that policies can be assessed, scenarios can be crafted, decision-makers can-in principle-be held to account. And in the seductive ways that metrics work in governance, targets may work themselves into mind sets and documents even after they have been shed of their methodological and substantive attire.

It has been argued that due to this metrical legibility of carbon, climate change is actually more open to politicisation than the sustainable development discourse was. Sustainable development has of course also been subject to quantification (Miller 2005), but has lent itself too easily to being incorporated in the growth paradigm and neoliberal modes of governance. By contrast, argue While and co-authors (2010), the discourse of carbon control represents "a harder edge to state environmental regulation via non-negotiable target setting...". Shifting focus from the ambiguous and co-optable idea of sustainability towards the more measurable problem of carbon control, they argue, opens up for a harder type of regulation.

Carbon control may introduce a new set of values into state regulation, which could open possibilities for challenging mainstream modes of urban development in ways not possible under the sustainable development discourse (While et al. 2010). Jonas et al. (2011) suggest that the ranking of cities on the basis of carbon emissions is becoming part of the competition between cities for investment capital, headquarter locations and attraction of educated workers. In other words, carbon control and its target are becoming part of the calculus behind "rational" urban governance.

We are probably not quite there yet. But at least target-setting is becoming normalised, which in turn legitimates a whole set of practices that may advance sustainable energy transitions. The next section examines a concrete chain of events to illustrate how this may occur. Given the scope of a short chapter, this case study is cursory. Yet it seeks to identify certain mechanisms for how climate targets are legitimated.

The concrete case I look at traces the $2^{\circ} \mathrm{C}$ target through the Norwegian Zero Growth Objective for urban transport. Within this, I am interested in how the climate problem, which has been distilled into a universal object of knowledge (as in the $2{ }^{\circ} \mathrm{C}$ target), cascades downwards in scale from the national to the local level. 


\subsection{Following the Target-Norway's Zero Growth Objective}

Norway's Zero Growth Objective for transport in urban areas is a useful illustration of how climate-related targets work their way into concrete policy-making. The goal itself states that all growth in personal traffic in the largest cities will be covered by public transport, walking and cycling. The "zero growth" aspect implied in this is of course that there will be no growth in private car traffic.

The legitimation of the target has been incremental, and involves multiple actors with divergent interests. Still, the progression from abstract target formulation towards a tangible foundation for concrete policy implementation is traceable by examining a series of key documents over time.

The contours of the Zero Growth Objective can be traced back at least to the 2006 White Paper on Norwegian Climate Policy [Meld. St. 34, 2006-2007]. There the government put forward some initial goals for climate-related policy in the transport sector, writing that there is a "need to shift the use of transport modes towards public transport, walking and cycling." The overarching reference for this White Paper was the international $2{ }^{\circ} \mathrm{C}$ target, adopted by the Norwegian government a year prior. While the $2{ }^{\circ} \mathrm{C}$ target is somewhat arbitrary and has been a source of controversy (Randalls 2010), it is referred to here and in most climate-related Norwegian national policy documents in a way that sets the level of ambition and points to the global urgency. The $2{ }^{\circ} \mathrm{C}$ target, notwithstanding the controversy over its origins and usefulness, is providing the framing for Norwegian policy, including the Zero Growth Objective back in 2006.

That formulation- "shift the use of transport modes towards public transport, walking and cycling" - can be found in all the key national climate policy documents from then on. The 2008 Climate Accord between all parties in Parliament minus one, the 2012 White Paper on Norwegian Climate Policy, and the 2012 Climate Accord, all use that same formulation with miniscule variations. Notably, however, the context in which that formulation is placed gets increasingly concrete and binding. In the 2012 White Paper, it is actually formulated as a target ("The Government has the goal that..."). Around the same time, the National Transport Plan Working Group put forward a proposition as an official goal of Norwegian transport policy, that the large cities should have zero growth except in "public transport, walking and cycling," and simultaneously coined the 
"Nullvekstmålet"-Zero Growth Objective. The leader of the Working Group has been quoted as saying "We wanted to find a target that was easy to measure, that would be ambitious and not least reachable" (quoted in Strand 2016).

Since then, the Zero Growth Objective has been mentioned, integrated and discussed in innumerable briefs, policy documents, talks and newspaper articles on transport policy in Norway. The way the target is formulated - with its simple quantification: "zero"-may account for some of its carrying power. And as a climate-related target, it has attained enormous success. It is an important element of the structural conditions for transport and mobility planning (Tennøy and Øksenholt 2018). We can quite concretely follow the process through which this occurs, through budget documents and funding agreements between the government and cities.

From 2014 onwards, the National Transport Plan adopted the Zero Growth Objective as the key target for transport policy in cities. The government, in launching the Urban Environment Agreements, also it was translated to a concrete agreement framework tied to a funding scheme for cities. It then transpired that the Government would negotiate with the largest cities in Norway and other regional authorities with responsibility for transport, to create "greater coherence in urban policy" by having these authorities collectively "commit to common goals written into the Urban Environment Agreements." Now, all relevant authorities are to sign a binding agreement on how to meet the Zero Growth Objective, and this agreement will be the basis for government funding for local transport.

From this point onwards, the amount of funding cities received for local transport infrastructure became tied to how well they worked towards meeting the Zero Growth Objective. This includes specific indicators that measure whether or not car traffic decreases. In 2016 and 2017, such Agreements were signed with Oslo, Trondheim, Bergen and Stavanger (Jæren); in short, the largest Norwegian cities.

Subsequently, the Zero Growth Objective has been mainstreamed and absorbed into the planning and land use regulation of the cities themselves. It is a ubiquitous condition for decision-making within the wide range of issues that affect the abilities of cities to reach the goal, such as location of housing, retail, transport infrastructure, congestion charging and much more. It introduces a simple calculus for decision-makers in cities: failure to meet the target will affect the amount of government money available in the next round of negotiations. Even beyond this, the 
effectiveness of the target transcends this simple calculus. It has become a standard reference point for ambitions in the climate field, and percolated into the urban policy discourse at many levels. Trends in actual traffic patterns are following suit-all cities mentioned above underwent a reduction in private car traffic in 2018 (Miljødirektoratet). Arguably, the target has contributed to normalising and routinising a way of thinking about transitions in cities that was considered highly ambitious only a few years ago.

\subsection{Legitimating Sustainable Transitions}

Are climate-related targets representative of a crisis of accountability, as pillars in a bureaucratic apparatus of governance that gives the appearance of climate action while little substantive change happens? Or are there mechanisms at work that translate abstract and arbitrary targets into concrete policy implementation? Most likely, a mix of these outcomes is at play. But the case of Norway's Zero Growth Objective illustrates some of the processes that legitimate and normalise an ambitious climate-related target. This involved soft mechanisms-inserting itself in the discourse on urban policy and moving its goal posts - and hard mechanisms-the conditioning of funding flows from national to local levels. To enable a sustainable energy transition, we need practices to legitimate the interventions that advance this transition. Under certain conditions, metrics and targets can play a constructive role in this.

\section{REFERENCES}

Bulkeley, H. (2006). Urban sustainability: Learning from best practice? Environment and Planning A, 38, 1029-1044.

Foucault, M. (1991). Governmentality. In G. Burchell, C. Gordon, \& P. Miller (Eds.), The Foucault effect: Studies in governmentality (pp. 87-104). London: Harvester Wheatsheaf.

Grandin, J., \& Sareen, S. (forthcoming). What sticks? Ephemerality, permanence and urban transformation pathways. In review.

Jasanoff, S. (2010). A new climate for society. Theory, Culture \& Society, $27,233-253$.

Jonas, A. E. G., Gibbs, D., \& While, A. (2011). The new urban politics as a politics of carbon control. Urban Studies, 48, 2537-2554.

Kramers, A., Wangel, J., Johansson, S., Höjer, M., Finnveden, G., \& Brandt, N. (2013). Towards a comprehensive system of methodological considerations for cities' climate targets. Energy Policy, 62, 1276-1287. 
Leal, V., \& Azevedo, I. (2016). Setting targets for local energy planning: Critical assessment and a new approach. Sustainable Cities and Society, 26, 421-428.

McCann, E. (2011). Urban policy mobilities and global circuits of knowledge: Towards a research agenda. Annals of the Association of American Geographers, 101, 107-130.

Methmann, C. P. (2010). 'Climate protection' as empty signifier: A discourse theoretical perspective on climate mainstreaming in world politics. Millennium: Journal of International Studies, 39, 345-372.

Miller, C. (2005). New civic epistemologies of quantification: Making sense of indicators of local and global sustainability. Science, Technology and Human Values, 30, 403-432.

Randalls, S. (2010). History of the $2^{\circ} \mathrm{C}$ climate target. WIREs Climate Change, $1,598-605$.

Rosenzweig, C, Solecki, W, Hammer, S. A., \& Mehrotra, S. (2010) Cities lead the way in climate-change action [Comment]. Nature, 467, 909-911.

Strand, A. (2016, August 24). Nullvekstmålet—tiljublet, men mangelfullt utredet. Samferdsel.

Swyngedouw, E. (2010). Apocalypse forever? Post-political populism and the spectre of climate change. Theory, Culture \& Society, 27, 213-232.

Tennøy, A., \& Øksenholt, K. V. (2018). The impact of changed structural conditions on regional sustainable mobility planning in Norway. Planning Theory e Practice, 19, 93-113.

While, A., Jonas, A., \& Gibbs, D. (2010). From sustainable development to carbon control: Eco-state restructuring and the politics of urban and regional development. Transactions of the Institute of British Geographers, 35, 76-93.

Open Access This chapter is licensed under the terms of the Creative Commons Attribution 4.0 International License (http://creativecommons.org/licenses/ by $/ 4.0 /$ ), which permits use, sharing, adaptation, distribution and reproduction in any medium or format, as long as you give appropriate credit to the original author(s) and the source, provide a link to the Creative Commons licence and indicate if changes were made.

The images or other third party material in this chapter are included in the chapter's Creative Commons licence, unless indicated otherwise in a credit line to the material. If material is not included in the chapter's Creative Commons licence and your intended use is not permitted by statutory regulation or exceeds the permitted use, you will need to obtain permission directly from the copyright holder.

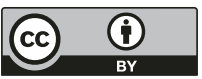




\title{
Governance and Legitimation in the Transition to Nordic Electric Mobility
}

\author{
Benjamin Sovacool
}

\begin{abstract}
The chapter draws from empirical data collected across Denmark, Finland, Iceland, Norway, and Sweden to examine some of the differing policy regimes and electric mobility pathways in the Nordic region, especially for electric vehicles (EVs). The chapter identifies emerging crises of contestation, accountability, and participation, and it considers whether electric mobility entrenches or challenges automobility. This last point is not a given, with EVs in some situations leading to greater amounts of driving and shifting mobility practices towards automobility, yet in others, EVs seem to promote more sustainable patterns of transport as well as shifts in values. The chapter lastly offers possible policy suggestions for a more just and equitable transition.
\end{abstract}

Keywords Electric vehicles $\bullet$ Electric mobility $\bullet$ Sociotechnical transitions $\bullet$ Social acceptance $\bullet$ Automobility

B. Sovacool $(\bowtie)$

Science Policy Research Unit, University of Sussex, Falmer, UK e-mail: b.sovacool@sussex.ac.uk

(C) The Author(s) 2020

S. Sareen (ed.), Enabling Sustainable Energy Transitions, https://doi.org/10.1007/978-3-030-26891-6_7 


\subsection{INTRODUCTION}

Conventional forms of automobility, with their dependence on privatelyowned, petroleum-powered vehicles used primarily by single occupants, are a significant source of major social ills including traffic jams and accidents, climate change, air pollution, and negative impacts on land use (Urry 2004). For example, the World Health Organization (2018a) estimates that every year 1.25 million people are killed and 20-50 million injured in traffic road crashes involving cars or motorcycles; globally, road traffic injuries are also the leading cause of death for those between the age of 15 and 29 years. In the realm of climate change, the Intergovernmental Panel on Climate Change (IPCC) notes that the transport sector produces about 7 billion tonnes of direct greenhouse gas emissions each year, making it responsible for almost one-quarter $(23 \%)$ of total energy-related carbon dioxide equivalent emissions (Sims et al. 2014). With regard to ambient air pollution, emissions of particulate matter and other hazardous pollutants from road traffic contribute to hundreds of thousands of premature deaths each year (World Health Organization 2018b). Even in Europe, some 40 million people across 115 of the largest cities in the European Union are exposed to air exceeding health guidelines (for at least one pollutant); in particular, children who reside close to roads with heavy-duty vehicle traffic have twice the risk of respiratory problems as those living near less congested streets (World Health Organization 2018b).

The race for more sustainable forms of passenger mobility has, therefore, commenced, with innumerable policymakers and other stakeholders exploring electric mobility and electric vehicles (EVs) as a promising pathway. This chapter draws on extensive empirical research in the five Nordic countries-Denmark, Finland, Iceland, Norway, and Sweden-looking at the transition to electric mobility there, as part of a project known as Nordic Vehicle-to-Grid, or NV2G (Noel et al. 2019b). This data includes:

- 257 expert interview participants across 17 cities in Denmark, Finland, Iceland, Norway, and Sweden (almost one million words of transcribed text) (Sovacool et al. 2018b, c);

- Eight focus groups in Aarhus, Bergen, Copenhagen, Gothenburg, Helsinki, Reykjavik, Stockholm, and Tampere (Noel et al. 2019c);

- A representative survey of 5000+ adult participants (Sovacool et al. 2018a) as well as an online choice experiment of preferences (Noel et al. 2019a); 
- 126 visits to car dealerships across the Nordic region (Zarazua de Rubens et al. 2018);

- Scenarios and simulations to capture co-benefits and determine systems optimisation (Noel 2017; Noel et al. 2017, 2018);

- Content analysis of standards for charging and grid interaction (Kester et al. 2019).

The chapter draws from this data to examine some of the differing policy regimes and electric mobility pathways in the Nordic region; identify emerging crises of contestation, accountability, and participation; consider whether electric mobility entrenches or challenges automobility; and offer possible policy suggestions for a more just and equitable transition.

\subsection{Differing Policy Regimes and Sociotechnical Pathways in the Nordic Region}

Within the transport studies literature, an abundance of terms are often used to describe electric mobility, including eco-mobility, electric vehicles, and micro-mobility (when referring to smaller cars or e-bikes and scooters). For the purposes of our project, we defined electric mobility as any form of mobility that uses energy drawn from the electric power grid, storing it on board for propulsion (She et al. 2017). This definition encompasses electric vehicles of all varieties-battery electric vehicles, plug-in hybrid electric vehicles, fuel-cell electric vehicles, and so on-but also electric bikes and scooters as well as the occasional trucks for freight or buses.

Despite this broad definition, the most popular form of electric mobility in the Nordic region remains the passenger electric vehicle, or EV. According to Kester et al. (2018), the Nordic countries do indeed have very different regimes for automobility and thus EVs and electric mobility. As Table 7.1 overviews, these differences begin with electricity markets, with Iceland not belonging to Nord Pool and great variation in the other four countries for consumers in terms of various fixed and flexible schemes, including an increasing number of hourly flexible plans based on the Nord Pool spot market. These differences on the electricity side continue on the respective car markets. The geography and differing income levels seems to lead to different car turnover rates ranging from 8.5 to almost 13 years. Regarding EVs, the countries have radically distinct levels of EV incentive programmes and markets. The all-inclusive 


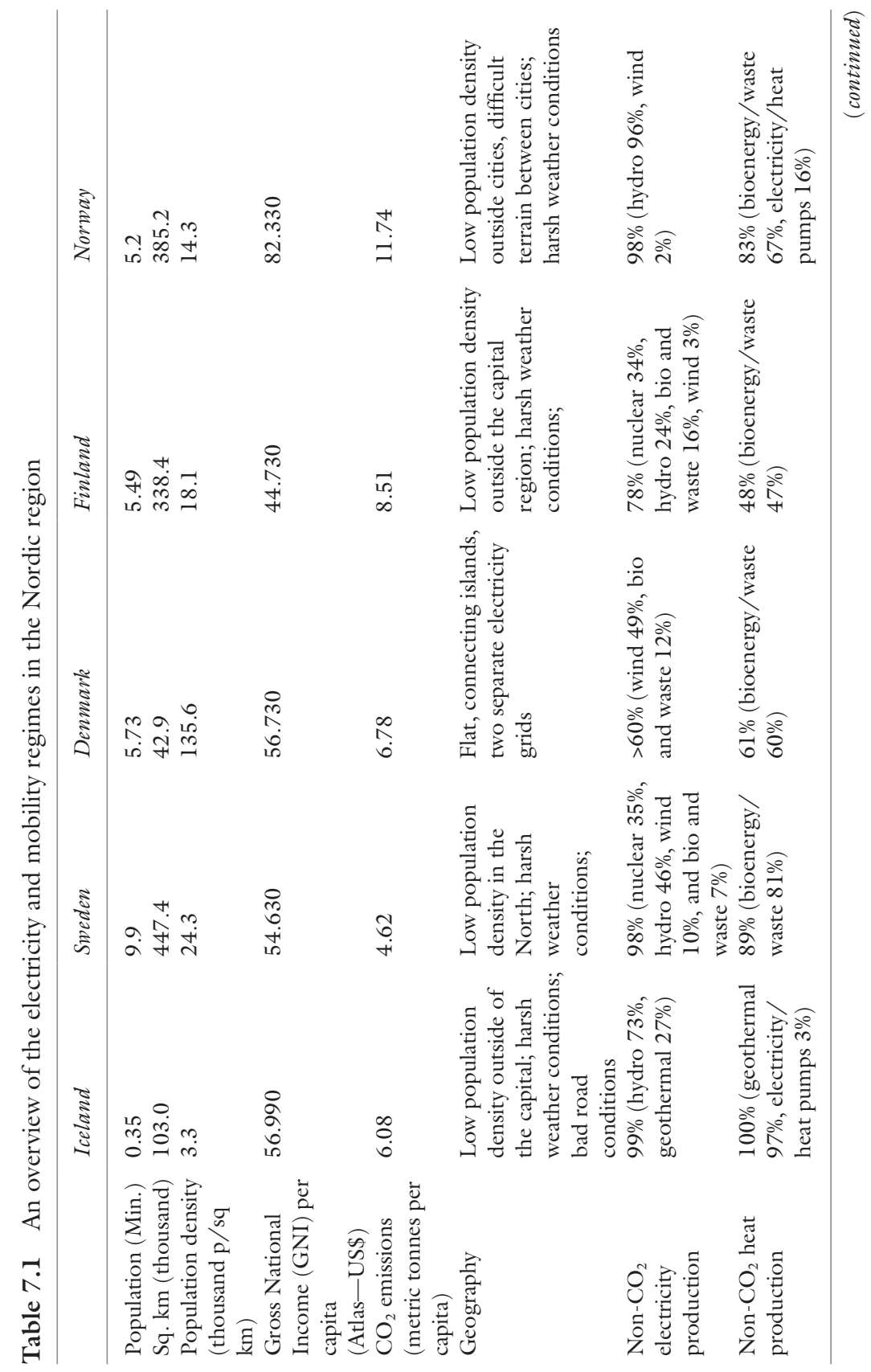




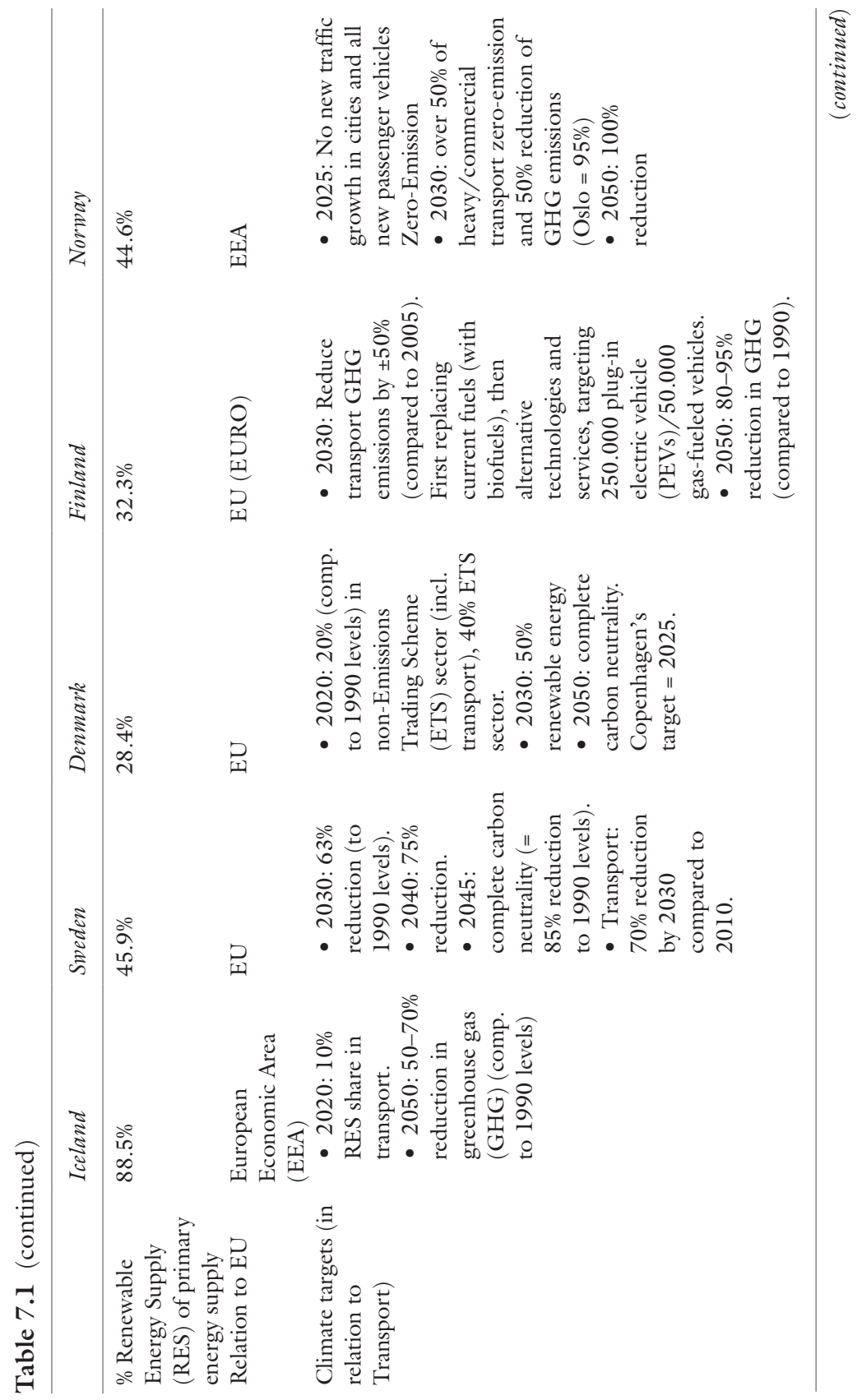




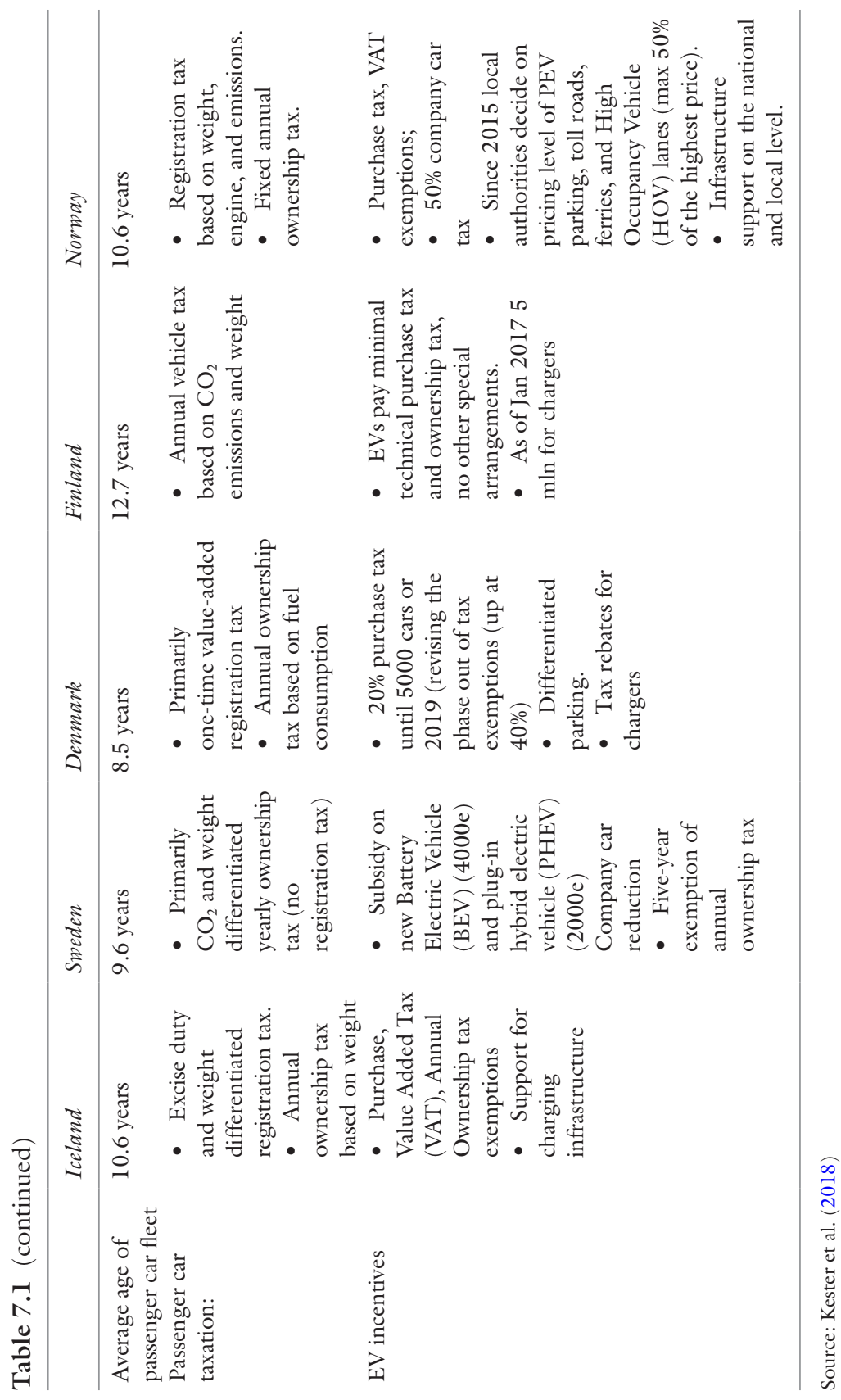


programmes of Norway are well known, but Iceland is also offering strong tax reductions, Sweden offers a cash subsidy (as it has fewer car taxes to reduce), Denmark recently halted the phase out of its earlier strong tax reductions for EVs (currently at $40 \%$ instead of $150 \%$ ) in an attempt to reinvigorate its $\mathrm{EV}$ sales and consumer trust in EVs, and in the case of Finland the EV incentives are fairly recent, in part due to Finnish comparative advantage in biofuels.

As Fig. 7.1 shows, these different support schemes are reflected in a different uptake of EVs as they lead to lower-in some cases competitive-consumer prices and time savings. And while Denmark stands out with its wind energy production, Norway stands out with its generous EV incentives, Finland has a large biofuel industry, and Sweden is the only country with a domestic automobile industry. All in all, the Nordic countries are different enough so that many of the major questions around electric mobility and vehicle-to-grid (V2G) come up, while they simultaneously offer flexible and modern electricity systems and a serious political concern about smog (Norway), oil imports (Iceland), and climate change (all of them) to take these developments seriously.

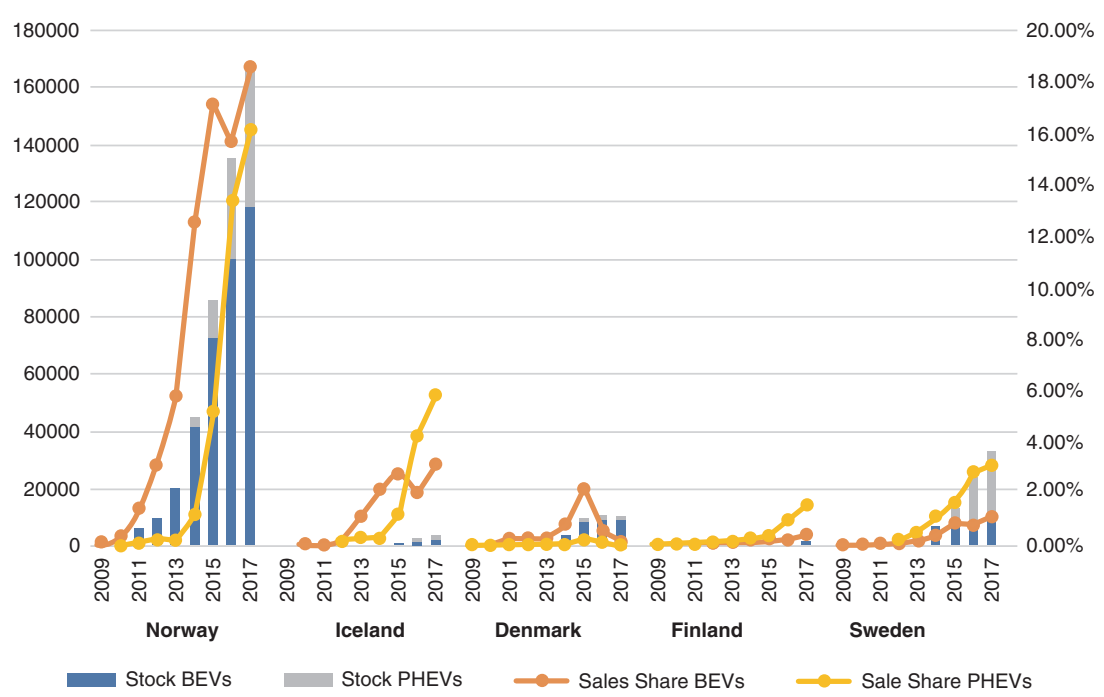

Fig. 7.1 Diffusion of electric vehicles in the five Nordic countries, 2009 to 2017. (Source: Kester et al. 2018) 
The Nordic region is thus a clear-cut example of where the transition to electric mobility is underway. For example, the International Energy Agency (2018) notes that across the five Nordic countries, the total stock of EVs reached 250,000 cars at the end of 2017 and accounted for $8 \%$ of the global total, the third-largest share after China and the United States. The per capita diffusion of EVs across the Nordic region is highest in the world at $10.6 \%$; the growth rate the highest in the world (up 57\% from the previous year); and Norway in particular features a 39\% market share of electric cars sales.

\subsection{Contests over Fairness, Participation, Environmental Governance, and Vulnerability}

However, even though the Nordic transition is underway, it has not been without its crises and contestations. Drawing from the empirical data from the NV2G project presented in Sovacool et al. (2019), this section explores these four challenges: inequitable access to EVs, exclusion and elitism in national planning, the creation of global externalities, and the worsening of some social vulnerabilities.

By far the most frequently mentioned injustice attribute across the entire sample of interview statements was that access to electric mobility technologies are not distributed evenly across Nordic society. As one respondent put it succinctly:

The most common EV in the Nordic Region is a Tesla. That's only for rich people and companies. It is not a mainstream car, it is not for everyone. It is a beautiful car, cool to have. But almost nobody can afford to.

Another was more elaborate in their reflection and highlighted the equity and justice challenge with electric mobility:

Tesla owners in Norway on average have a quite high income. The Tesla is not their only car, they can have it as maybe their second or third or fourth or fifth car. It's the wealthy getting in front of the common people so they can just pass them in the queue in the morning, and that's irritating ... A recent newspaper found that the typical, single Tesla Model X owner received subsidies in 2016 worth the same amount you can hand out to provide 30,000 trips on the buses and the subway system of Oslo. 
If accurate, such a statement even quantifies the equity issues, placing a single EV adopter above the needs of thousands of public transport users-it privileges one "wealthy" person over 30,000 potential "common people."

In the domain of energy democracy and public participation, respondents raised concerns that EVs only created (or were backed by) exclusionary policies and reflected elitism in national planning and policymaking. Essentially, these comments draw on or connect with some of the distributive justice issues mentioned above, such as equity, but relate it back to procedures and the regulatory process. In this way, issues of unfair access and elitism become reflected and entrenched in policy, which then further perpetuate inequity across mobility systems. For instance, one respondent suggested that:

In the beginning, I thought the negative reactions to Teslas was related to envy or jealousy. But after thinking more about it, it's a rational and emotional reaction. Why should we lose a lot of money for rich people getting a cheap, expensive, luxury car? The politicians ... are [being] controlled.

Another framed this as a procedural justice issue about policy, rather than one purely of distributive justice:

People see EVs as only for the upper class. They find them very unfair. To the politicians, electric mobility sounds very good and they remain convinced that EVs can help store energy, decarbonize transport, and balance the grid.

Yet another elaborated that:

In Finland, government policy for EVs has been socially catastrophic, because only rich people buy new Teslas (laughs).

Other respondents mentioned the problem as one of "politicians prioritising between hundreds of goals," and perhaps lacking the "political will" to make controversial decisions or challenge entrenched interest.

At another level, respondents mentioned that the widespread adoption of electric mobility systems, especially in a vehicle-to-grid (V2G) configuration, could potentially erode democratic processes, and undermine people's autonomy or liberty. One respondent, for example, noticed a reluctance among consumers to "become dependent on some distant 
infrastructure for their daily travel." Another illustrated another part of the logic of this vision when noting "people are afraid that the batteries will not last long enough and it is very costly to get new ones." This last statement underscores the potential for a V2G system to become more easily controlled by profiteering companies-creating an exclusionary innovation system or policy regime.

The global externality issues connected to electric mobility largely touch on externalities - in various domains (environmental, community, market) and scales (local, national, global). In the environmental domain, some literature has noted that EVs, in particular, can lead to externalities such as greenhouse gas emissions from electricity use, toxic pollution from battery manufacturing and disposal, and water consumption. In terms of climate change, for EVs to actually deliver well-to-wheels carbon reductions, the carbon content of electric power generation must be low. Otherwise, EVs will simply shift the exposure to air pollution away from urban areas and towards rural populations located closer to the power plants that provide electricity for recharging EV batteries in the city. One respondent offered an illustrative statement underscoring environmental concerns in the context of plug-in hybrid EVs. They noted:

The problem with plug-in hybrid EVs in the region is that they can switch between fossil fuels (gasoline or diesel) and all electric mode. Many of such cars are bought by rich people not bothering to plug it in, driving it in pure fossil mode all the time only to save 100,000 to 200,000 kroner in taxes. They buy the car but never intend to use the environmental package, so that's obvious that you need some scheme to stimulate the real zero emission driving.

In addition, some research has suggested that EVs shift pollution from local places and make it more regional; it also depends on local fuel mixes whether a net benefit to health or greenhouse gas emissions occur. Furthermore, the production of EVs requires equipment and material inputs that raise concerns about toxicity and recycling. Electric drivetrains, motors, and batteries need lithium, nickel, copper, and aluminium, as well as critical materials, somewhat harder to find, such as cobalt and indium. In this context, the possible environmental benefits of an electric mobility transition-fewer greenhouse gas emissions and improved air quality in urban environments-may come at the cost of greater pollution from factories making components and the landfills and junkyards where obsolete models end up. A final issue falls in the community domain, where externalities to greater electric mobility adoption include greater risk of 
accidents and traffic congestion, given that vehicles and e-bikes can still promote an automobility paradigm that transportation should be private, rather than public, and motorised rather than human-powered.

A final area of contestation relates to vulnerability, especially jobs (notably small and independent fuel providers and maintenance firms) and impacts on rural residents. In the Nordic region, many petrol and fuel stations would need to instal electric charging infrastructure, a prohibitively costly endeavour. Automotive dealerships and maintenance firms would also see a potentially large loss of revenue, as well as those selling alternatives to electric vehicles such as small-scale biofuel or hydrogen companies, a growing industrial segment at least in Denmark. Within Nordic automotive dealerships specifically, Zarazua de Rubens et al. (2018) found that salespersons generally articulate that EVs take a longer time to sell, take more effort to sell, and result in less revenue for maintenance-which can all result in negative impacts on profitability for automotive companies and dealerships, and consequently jobs, in the short term.

\subsection{Legitimating or Challenging Automobility?}

A deeper concern, separate from contests and challenges to accountability or equality, concerns whether EVs are in fact a radical, transformative innovation that challenges automobility, or an incremental, supportive innovation that only further entrenches it. In Table 7.2, for example, we show all of the positive and negative synergies electric mobility can have with sustainability. As that table highlights, electric mobility can potentially displace large amounts of carbon for passenger vehicles and even fleets, but also run the risk of further embedding motorised, private automobility as well as increased driving. Graham-Rowe et al. (2012) note for example that because adopters perceived their EVs to be more "environmentally-friendly," they drove them 1.64 times further than cars they did not see as "eco-cars." Some drivers even attempted to recharge their vehicles not by plugging in at home or at work, but by running the internal combustion engine and then using the re-generative braking system to "charge" their vehicle- "thereby negating the carbon savings" (Graham-Rowe et al. 2012: 148). This underscores that EVs can entrench automobility without necessarily decarbonising.

Part of this tension stems from the material, discursive and cultural elements that re-perform the core elements of the automobility regime. On 
Table 7.2 Positive and negative synergies with electric mobility and sustainability

\begin{tabular}{|c|c|c|}
\hline Dimension & $\begin{array}{l}\text { Reinforces sustainable } \\
\text { automobility }\end{array}$ & $\begin{array}{l}\text { Reinforces unsustainable } \\
\text { mobility }\end{array}$ \\
\hline Intermodality & $\begin{array}{l}\text { Use of EV within systems of } \\
\text { intermodality, in combination } \\
\text { with measures to discourage car } \\
\text { use }\end{array}$ & $\begin{array}{l}\text { Use of EV in systems that } \\
\text { encourage excessive driving } \\
\text { and EVs as second or third } \\
\text { (luxury) cars }\end{array}$ \\
\hline $\begin{array}{l}\text { Desire for motorised } \\
\text { transport }\end{array}$ & Substitution of cars and scooters & Increase in car-based mobility \\
\hline Organised car sharing & $\begin{array}{l}\text { Use of EVs in car sharing/ } \\
\text { ride-sharing schemes }\end{array}$ & $\begin{array}{l}\text { Increase in preferences for } \\
\text { private, single-occupancy } \\
\text { driving practices }\end{array}$ \\
\hline Increases in mobility & $\begin{array}{l}\text { Implemented in tandem with } \\
\text { active transport planning } \\
\text { (walking, cycling) }\end{array}$ & $\begin{array}{l}\text { Extra car trips, multiple car } \\
\text { ownership, displaces } \\
\text { enthusiasm for cycling }\end{array}$ \\
\hline $\begin{array}{l}\text { Zero-carbon and low } \\
\text { carbon electricity }\end{array}$ & $\begin{array}{l}\text { Use of EV in countries with } \\
\text { decarbonised electricity grids }\end{array}$ & $\begin{array}{l}\text { Use of EV in countries with } \\
\text { coal-based electricity }\end{array}$ \\
\hline Smart grids & $\begin{array}{l}\text { Charging at off-peak times and } \\
\text { storage for peak demand }\end{array}$ & $\begin{array}{l}\text { Charging at peak times with } \\
\text { no storage }\end{array}$ \\
\hline $\begin{array}{l}\text { Critical materials } \\
\text { scarcity }\end{array}$ & $\begin{array}{l}\text { Efficient manufacturing } \\
\text { techniques with an appreciation } \\
\text { for externalities with battery } \\
\text { recycling }\end{array}$ & $\begin{array}{l}\text { Inefficient and polluting } \\
\text { manufacturing techniques with } \\
\text { no battery recycling }\end{array}$ \\
\hline $\begin{array}{l}\text { Employment, } \\
\text { competitiveness, and } \\
\text { growth }\end{array}$ & $\begin{array}{l}\text { Designed and promoted by } \\
\text { sustainable firms with a focus on } \\
\text { innovation and entrepreneurship }\end{array}$ & $\begin{array}{l}\text { Coopted and marginalised by } \\
\text { transnational conglomerates } \\
\text { with little desire for social } \\
\text { change }\end{array}$ \\
\hline
\end{tabular}

Source: Sovacool (2017)

Note: $\mathrm{EV}=$ Electric vehicle

both landscape and regime level, for example, the system locks itself in through constructed infrastructure, traffic rules and regulations, expertise (in terms of personnel and beliefs), travel routines, cultural values around enjoyment, status and freedom, and incumbent industries.

\subsection{Policy Suggestions for a More Just and Sustainable Transition}

Nonetheless, the sustainability credentials of EVs can be captured by an aggressive and proactive policy. If EVs are determined by policymakers to play an essential role in national climate change mitigation plans, our data 
suggests several policies to prevent or at least minimise injustice in Table 7.3. Thus, our justice framework shows that policymakers need to think broadly when implementing EVs in order to avoid half-measures of energy justice.

In addition, many of the areas of contestation, or the issues of equity and vulnerability that arise, are not "new" to EVs or V2G-they likely exist with other low carbon technologies and also conventional cars and other forms of mobility. However, a lesson here is perhaps that changing the perfor-

Table 7.3 Policy mechanisms for more sustainable and just Nordic electric mobility

\begin{tabular}{|c|c|c|}
\hline $\begin{array}{l}\text { Area of } \\
\text { contestation }\end{array}$ & Example(s) & Policy response \\
\hline Unfair access & $\begin{array}{l}\text { EVs only accessible by } \\
\text { higher socioeconomic } \\
\text { consumers }\end{array}$ & $\begin{array}{l}\text { Avoid regressive EV subsidies, encourage } \\
\text { lower-cost EV development, increase } \\
\text { consumer knowledge of cheaper EVs }\end{array}$ \\
\hline $\begin{array}{l}\text { Elitism in } \\
\text { planning and } \\
\text { policymaking }\end{array}$ & $\begin{array}{l}\text { EV policy determined in } \\
\text { scope of higher } \\
\text { socioeconomic consumers } \\
\text { Exclusion of other subsets } \\
\text { of the population (low } \\
\text { income, users of other } \\
\text { mobility) }\end{array}$ & $\begin{array}{l}\text { Better inclusion of the entire population in } \\
\text { EV policies (e.g. public charging } \\
\text { infrastructure coverage), } \\
\text { Broader electrification of public transport, } \\
\text { more comprehensive transport policy, } \\
\text { progressive EV, and V2G subsidies }\end{array}$ \\
\hline $\begin{array}{l}\text { Lifecycle } \\
\text { externalities }\end{array}$ & $\begin{array}{l}\text { EVs exacerbate other } \\
\text { externalities (congestion, } \\
\text { electricity-related } \\
\text { externalities) } \\
\text { Global south excluded } \\
\text { from EVs, instead get } \\
\text { cheap petrol/diesel }\end{array}$ & $\begin{array}{l}\text { Deployment of EVs requires deployment of } \\
\text { other renewable electricity, transportation } \\
\text { planning policies, internalising externalities, } \\
\text { carefully managing battery and lifecycle waste } \\
\text { streams } \\
\text { Shift international focus of EVs beyond } \\
\text { global North, international mechanisms to } \\
\text { shift technology and support small EV } \\
\text { initiatives present in those countries (clean } \\
\text { development mechanism policy) }\end{array}$ \\
\hline $\begin{array}{l}\text { Vulnerable } \\
\text { groups }\end{array}$ & $\begin{array}{l}\text { Conventional car industry } \\
\text { job loss, particularly } \\
\text { maintenance } \\
\text { Dealership resistance to } \\
\text { selling new technologies }\end{array}$ & $\begin{array}{l}\text { Implement job training programmes for new } \\
\text { EV industry (e.g. battery specialisation, } \\
\text { EVSE repair, V2G aggregation) similar to } \\
\text { coal-to-solar transition } \\
\text { Consistent EV and V2G policy signals, } \\
\text { allowing industry preparation and investment } \\
\text { for EV transition }\end{array}$ \\
\hline
\end{tabular}

Source: Sovacool et al. (2019)

Note: $\mathrm{EV}=$ Electric vehicle, $\mathrm{V} 2 \mathrm{G}$ = Vehicle-to-grid, EVSE = Electric vehicle supply equipment 
mance or engine of a vehicle, or introducing a new type of car such as an $\mathrm{EV}$ or an innovation such as $\mathrm{V} 2 \mathrm{G}$, does not necessarily change the underlying political economy or power dynamics behind mobility or automobility. Systems of mobility themselves-involving multiple, competing and overlapping technologies, modes of mobility, and transport infrastructurescan also be just or unjust, even if they utilise innovations such as EVs or $\mathrm{V} 2 \mathrm{G}$ that have material potential to reduce environmental and social harms. There may be situations, practices, or socio-material configurations where V2G EVs meet principles of justice, sustainability, or sustainable development, but also areas where they may not (such as when an EV reinforces automobility and merely represents an additional car, and thus becomes a net environmental burden, or increases the demand for motorised mobility at the expense of more active walking and cycling). The sociotechnical potential of electric mobility is, therefore, situational, relational, and contingent. The answer to the question "Is it good?" will invariably be "It depends." The chapter has aimed to provide an overview of what it depends on, to inform an accountable and sustainable energy transition.

\subsection{Conclusion}

To conclude, the inherent promise embodied in electric mobility is just that, potential not yet fully realised. Its regional and perhaps even global deployment pathways, its future potential or vision, will differ considerably depending on context and policy. Electric mobility is at a pivotal moment in its development where it could merely reinforce aspects of conventional mobility-where society instead adopts more efficient conventional cars, or other alternative modes and fuels such as biofuel or hydrogen. Or, electric mobility could remain trapped as a niche, an important but by no means dominant system of mobility. Alternatively, perhaps electric mobility will reach high penetrations across a dirty grid, a decarbonised grid, or a super-smart high-tech digitised grid. Which of these pathways becomes a reality is contingent and context-specificwhich reveals the promise, but also the peril, of electric mobility.

\section{REFERENCES}

Graham-Rowe, E., Gardner, B., Abraham, C., Skippon, S., Dittmar, H., Hutchins, R., \& Stannard, J. (2012). Mainstream consumers driving plug-in batteryelectric and plug-in hybrid electric cars: A qualitative analysis of responses and evaluations. Transportation Research Part A: Policy and Practice, 46, 140-153. 
International Energy Agency. (2018). Nordic EV outlook 2018: Insights from leaders in electric mobility. Paris: OECD.

Kester, J., Noel, L., Lin, X., Zarazua de Rubens, G., \& Sovacool, B. K. (2019, January). The coproduction of electric mobility: Selectivity, conformity and fragmentation in the sociotechnical acceptance of vehicle-to-grid (V2G). Journal of Cleaner Production, 207, 400-410.

Kester, J., Noel, L., Zarazua de Rubens, G., \& Sovacool, B. K. (2018, May). Promoting vehicle to grid (V2G) in the Nordic region: Expert advice on policy mechanisms for accelerated diffusion. Energy Policy, 116, 422-432.

Noel, L. (2017). The hidden economic benefits of large-scale renewable energy deployment: Integrating heat, electricity and vehicle systems. Energy Research \&. Social Science, 26, 54-59.

Noel, L., Brodie, J., Kempton, W., Archer, C., \& Budischak, C. (2017). A cost minimization model of electricity production and transportation with considerations of externalities. Applied Energy, 189, 110-121.

Noel, L., Zarazua de Rubens, G., \& Sovacool, B. K. (2018, June). Optimizing innovation, carbon and health in transport: Assessing socially optimal electric mobility and vehicle-to-grid (V2G) pathways in Denmark. Energy, 153, 628-637.

Noel, L. D., Carrone, A. P., Jensen, A. F., Zarazua, G. D. R., Kester, J., \& Sovacool, B. K. (2019a, February). Willingness to pay for electric vehicles and vehicle-to-grid applications: A Nordic choice experiment. Energy Economics, $78,525-534$.

Noel, L., Kester, J., Zarazua de Rubens, G., \& Sovacool, B. K. (2019b). Vebicleto-grid: A sociotechnical transition beyond electric mobility. Basingstoke: Palgrave Macmillan.

Noel, L. D., Zarazua de Rubens, G., Sovacool, B. K., \& Kester, J. (2019c, February). Fear and loathing of electric vehicles: The reactionary rhetoric of range anxiety. Energy Research \& Social Science, 48, 96-107.

She, Z.-Y., Sun, Q., Ma, J.-J., \& Xie, B.-C. (2017). What are the barriers to widespread adoption of battery electric vehicles? A survey of public perception in Tianjin, China. Transport Policy, 56, 29-40.

Sims, R., Schaeffer, R., Creutzig, F., Cruz-Núñez, X., D’Agosto, M., Dimitriu, D., ... Tiwari, G. (2014). Transport. In O. Edenhofer, R. Pichs-Madruga, Y. Sokona, E. Farahani, S. Kadner, K. Seyboth, A. Adler, I. Baum, S. Brunner, P. Eickemeier, B. Kriemann, J. Savolainen, S. Schlömer, C. von Stechow, T. Zwickel, \& J. C. Minx (Eds.), Climate change 2014: Mitigation of climate change. Contribution of Working Group III to the Fifth Assessment Report of the Intergovernmental Panel on Climate Change. Cambridge, UK and New York, NY: Cambridge University Press.

Sovacool, B. K. (2017, May). Experts, theories, and electric mobility transitions: Toward an integrated conceptual framework for the adoption of electric vehicles. Energy Research \& Social Science, 27, 78-95. 
Sovacool, B. K., Kester, J., Noel, L., \& Zarazua de Rubens, G. (2018a, September). The demographics of decarbonizing transport: The influence of gender, education, occupation, age, and household size on electric mobility preferences in the Nordic region. Global Environmental Change, 52, 86-100.

Sovacool, B. K., Kester, J., Zarazua de Rubens, G., \& Noel, L. (2018b, April). Expert perceptions of low-carbon transitions: Investigating the challenges of electricity decarbonisation in the Nordic region. Energy, 148, 1162-1172.

Sovacool, B. K., Noel, L., Zarazua de Rubens, G., \& Kester, J. (2018c, December). Reviewing Nordic transport challenges and climate policy priorities: Expert perceptions of decarbonisation in Denmark, Finland, Iceland, Norway, Sweden. Energy, 165, 532-542.

Sovacool, B. K., Noel, L. D., Zarazua de Rubens, G., \& Kester, J. (2019, March). Energy injustice and Nordic electric mobility: Inequality, elitism, and externalities in the electrification of vehicle-to-grid (V2G) transport. Ecological Economics, 157, 205-217.

Urry, J. (2004). The 'system' of automobility. Theory, Culture \& Society, 21, 25-39. World Health Organization. (2018a). Road traffic injuries: Key facts, February 19. Retrieved from http://www.who.int/news-room/fact-sheets/detail/ road-traffic-injuries

World Health Organization. (2018b). Air pollution and climate change. Retrieved from http://www.euro.who.int/en/health-topics/environment-and-health/ Transport-and-health/data-and-statistics/air-pollution-and-climate-change2

Zarazua de Rubens, G., Noel, L., \& Sovacool, B. K. (2018, June). Dismissive and deceptive car dealerships create barriers to electric vehicle adoption at the point of sale. Nature Energy, 3, 501-507.

Open Access This chapter is licensed under the terms of the Creative Commons Attribution 4.0 International License (http://creativecommons.org/licenses/ by $/ 4.0 /$ ), which permits use, sharing, adaptation, distribution and reproduction in any medium or format, as long as you give appropriate credit to the original author(s) and the source, provide a link to the Creative Commons licence and indicate if changes were made.

The images or other third party material in this chapter are included in the chapter's Creative Commons licence, unless indicated otherwise in a credit line to the material. If material is not included in the chapter's Creative Commons licence and your intended use is not permitted by statutory regulation or exceeds the permitted use, you will need to obtain permission directly from the copyright holder.

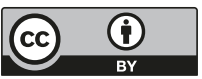




\title{
Accountability and the Regulation of Legitimacy: Biodiversity Conservation and Energy Extraction in the American West
}

\author{
Steven Wolf
}

\begin{abstract}
Energy extraction in the western United States poses existential risks to sage-grouse, a charismatic ground-nesting bird. Study of how this concern is integrated into the governance of the sector can inform a broader analysis of sustainability transitions. I introduce a model of coevolution of standards of legitimacy and material practices that highlights how emergence of new accountability 'tests' can potentially drive socioecological transformation. This evolutionary model emphasises accountability and legitimacy as mechanisms of selection (demographic/ behavioural change). Because accountability mechanisms and selection pressures do not exist to transform the Colorado energy sector in a manner that benefits sage-grouse, the assessment reveals that there is no sustainability transition underway. As we focus on the broader analytical and practical challenges presented by sustainability transitions, attention to accountability, legitimacy, and selection mechanisms will be essential.
\end{abstract}

Keywords Sustainable transitions $\bullet$ Accountability $\bullet$ Legitimacy $\bullet$ Biodiversity conservation $\bullet$ Environmental governance

S. Wolf $(\bowtie)$

Department of Natural Resources, Cornell University, Ithaca, NY, USA

e-mail: saw44@cornell.edu

(C) The Author(s) 2020

S. Sareen (ed.), Enabling Sustainable Energy Transitions, https://doi.org/10.1007/978-3-030-26891-6_8 


\subsection{Energy Production and Loss of Biodiversity}

The sage-grouse (Centrocercus urophasianus) is a ground-nesting bird dependent on sagebrush steppe habitat in 11 western states in the United States. The population is in marked decline, with the current range of the species reduced to $56 \%$ its historic distribution (Schroeder et al. 2004). Following formal petitions, US Fish and Wildlife Service concluded an assessment in 2010 (USFWS 2010) to determine if the sage-grouse should be protected under the Endangered Species Act (ESA). In 2010, the federal government determined that protections were warranted based on population estimates and ecological modelling, but that it was not practical to implement protections under the law due to competing demands on the agency. The federal government invited the relevant states to develop conservation plans that would protect the habitat (and ostensibly the population) of sage-grouse. Inducing the creation of these conservation plans can be understood as a means of fulfilling obligations that flow from the Endangered Species Act.

In Colorado, oil and gas development is the leading cause of sagegrouse habitat degradation (Copeland et al. 2009). A leading environmental non-governmental organisation (NGO), Environmental Defense Fund (EDF), organised relevant stakeholders to develop the Colorado Habitat Exchange, a compensatory mitigation programme through which the oil and gas industry could purchase habitat credits to offset habitat degradation associated with their operations. The credits would be supplied by farmers and ranchers who commit to conservation or restoration of land, thereby producing positive gains in habitat. In this way, energy development could be rendered compatible with a commitment to no-net loss of sage-grouse habitat.

In terms of socioecological interplay and feedbacks, energy demand/ supply causes land use disturbance, resulting in sage-grouse population declines and awareness of risks of ecological disturbance. This has the potential to drive social regulation (i.e., the introduction of accountability mechanisms that encourage firms to avoid destroying valuable habitat and to offset habitat loss when avoidance is not practical), which can, in turn, change land use patterns to stabilise populations of sage-grouse. As depicted, this dynamic can be understood as a transition from a situation in which the energy industry contributes in a significant way to risk of sage-grouse extinction to a situation in which the energy industry responds 
to social demand for biodiversity protection and contributes positively to sage-grouse conservation success.

While energy transitions are generally understood to involve a shift from fossil fuels to renewable energy supply, it is useful to consider other challenges. Adaptations that address protection of wildlife, water quality, air quality, workers, and communities where extraction and processing occur all represent important challenges to the industry, the economy, and to social capacity for regulation. Studying the integration of biodiversity concerns into energy development can inform understanding of prospects for sustainability, broadly defined. More generally, this work can demonstrate how attention to accountability and legitimacy can support analysis of environmental governance.

\subsection{Legitimation Crisis, Regulation, and Socioenvironmental Change: An Evolutionary Model of Environmental Governance}

The framing of this volume places accountability and legitimation processes at the centre of environmental governance (see Kraft and Wolf 2018). Accountability mechanisms provide assurance against unacceptable behaviour and serve to regulate flows of legitimacy. Legitimacy is understood to be a socially mediated resource that shapes the prospects of actors, rewards and constrains behaviour, and channels socioeconomic development (e.g., industrial organisation) and material practices (e.g., techniques for producing energy). As contributing authors to this volume, we are asked to analyse practices of legitimation that serve to disrupt-as well as conserve-business as usual in order to advance scholarship on sustainability transitions. At the same time, we are encouraged to identify opportunities to challenge and to change practices/relations of accountability and flows of legitimacy in order to advance sustainability transitions.

Habermas' (1975) analysis of the legitimation crisis draws our attention to systemic dimensions of technical and institutional change within imagined sustainability transitions. For Habermas, the crisis is a state in which there are no problem-solving pathways available to incumbent decision makers. The control/regulatory apparatus is perceived as not being capable of repair or renewal. The anticipated outcome is disruptive innovation, qualitative change; a shift to a different state. 'To the extent that (ecological) scarcity is a technical problem, this does not necessarily constitute a 
crisis. The crisis stems from lack of institutional alternatives. What is scarce is coordination capacity. We do not have proven, practical institutional responses to what ails us, or at minimum, the switching costs and the learning challenges make transition frightening' (Wolf and Bonanno 2014: 287). In these terms, a crisis of legitimacy has the potential to catalyse a transition, some forms of which might be called sustainable. ${ }^{1}$ This transition will entail both technical and institutional state variables. We have not advanced very far in some imagined transition towards sustainability (e.g., reduced reliance on fossil fuels and reduced $\mathrm{CO}_{2}$ flux and reductions in economic stratification), and so it is possible to suggest that there is no legitimation crisis. In other words, people do not interpret the situation in terms of institutional failure. Consumer capitalism appears quite sustainable, and core debates are framed in technical (i.e., post-political (Swyngedouw 2009)) terms. Dominant institutions, dominant actors, and dominant material practices are able to reproduce their legitimacy despite social and ecological contradictions (Piketty 2013; Rockström et al. 2009). For this reason, this book is focused on questions about how this legitimacy is maintained and how new accountability practices might alter flows of legitimacy and advance a sustainability transition.

Science and technology studies has developed the concept of sociotechnical systems, highlighting the mutual embeddedness of social processes and technology. This integrated perspective is rather central to the sustainability transitions literature. In trying to make sense of sociotechnical change and processes of regulation, I identify flows of legitimacy and accountability 'tests' as essential considerations (see top right in Fig. 8.1). Such tests can take the form of laws, administrative rules, professional best practices, technical standards, cultural conventions, investment and consumption behaviours, and other social processes that structure discrimination routines (i.e., processes of selection within an ecological model). Processes of selection, or regulation, are central to an analysis of mechanisms that might produce a sociotechnical transition or rapid 'flip' (i.e., state change) into something we might identify as sustainability. They are also central to the analysis of how sustainability imperatives are blunted and co-opted. Blühdorn (2007) has emphasised the need to analyse how we 'sustain the unsustainable'. The reproduction of selection mechanisms/environments - that is, standards of legitimacy and mechanisms of

\footnotetext{
${ }^{1}$ Authoritarianism is a possible outcome, and the relationship between authoritarianism and sustainability requires reflection.
} 


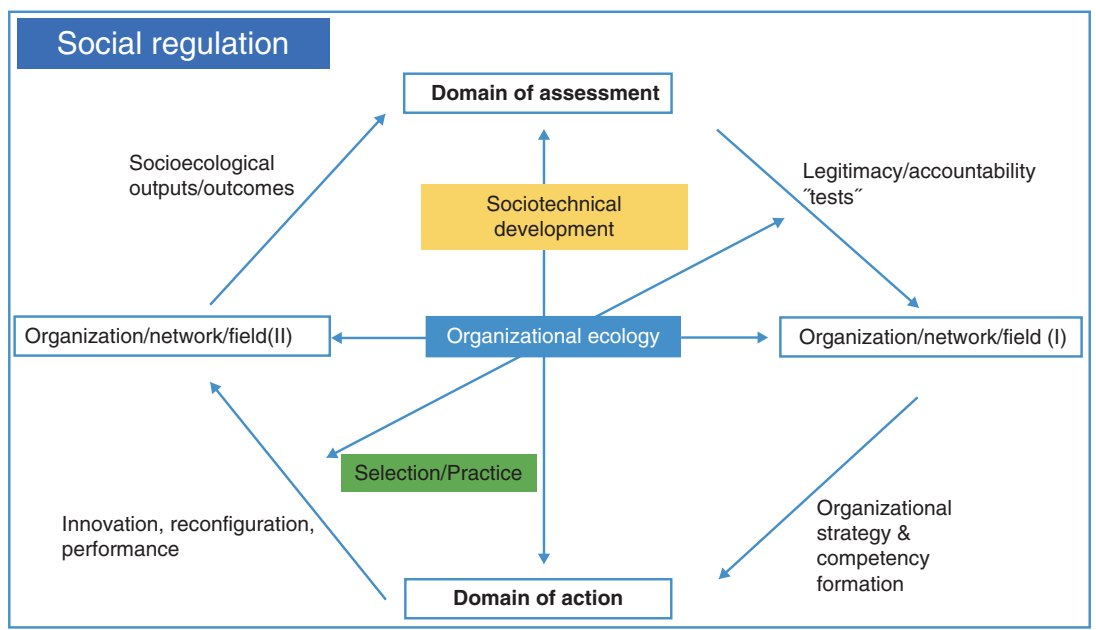

Fig. 8.1 Co-evolution of nature and society mediated by accountability mechanisms and legitimacy tests

accountability - that fail to change the distribution of relevant behaviours and outputs are a central mechanism for path dependence in socioecological systems.

Selection is the process that drives demographic change and demographic stability (i.e., organisational ecology). Here, we can imagine a population of oil and gas firms with variable capacity to respond to new regulations, new eco-audits, or new consumer sensibilities (Wolf and Primmer 2006). In addition to demographic change, selection can alter the distribution of behaviours. Firms adapt more frequently than they disappear. We can imagine the costs of offsetting the degradation of sagegrouse habitat as driving some firms out of business (i.e., churn in the population), and we can imagine such costs as shifting firms' drilling operations to geographic zones outside of prime sage-grouse habitat (an adaptation of technical practices and outputs).

The co-evolutionary model sketched in Fig. 8.1 can help us make sense of incremental processes of socioecological change (adaptation) as well as rapid flips (punctuated equilibrium). Regardless of the pace of change, the analysis presented here emphasises linkages between socially mediated assessments, economic and technical development, and socioecological change (see Norgaard 1994). 
As represented in the model, standards of assessment emerge from culture, politics, and scientific interpretations of socioecological status and trajectory (e.g., changes in biodiversity and the stakes attached to it). Accountability represents a series of relational ties that position some actors to make judgements of others and impose sanctions when appropriate (Bovens 2007). Judgements are based on assessments of how well a given practice or organisation conforms to norms that derive from deep structures of society (i.e., institutions such as family, community, market, state, etc.) (Kraft and Wolf 2018). Sanctions-penalties, taxes, withdrawal of subsidies, consumer boycott, investor flight-hinder performance and reduce competitiveness, by definition, and in this sense, they are an element of selection processes (i.e., organisational ecology). At the same time, shifting standards of accountability and shifts in how legitimacy is produced/accessed gives rise to new organisational strategies and new competencies tied to emerging competitive strategies (Wolf and Primmer 2006). Out of this adaptation dynamic, we observe innovation and reconfiguration of material practices.

Changes in the institutional environment and the competitive landscape also give rise to gestures or performances that communicate engagement with norms, but amount to little material change that can be linked back in any direct way to the new accountability tests mentioned earlier. ${ }^{2}$ Note that these performances-for example, ways of talking about sustainability concerns - can be an element of a new competitive landscape, and in this sense, they are not empty. This dynamic of adaptation-substantive and gestural-produces a newly configured population (i.e., organisation/network/field II), which is characterised by a different distribution of behaviours as well as the introduction of new material practices. These developments constitute socioecological change, and outcomes include changes in ecology and distributional shifts in the wellbeing of people and ecosystems. These outcomes give rise to new ecological risks and opportunities and new social values and politics. In this shifting cognitive and sociomaterial landscape, the stage is set for a new round of assessments and evaluations that constitute accountability practices and structure flows of legitimacy.

\footnotetext{
${ }^{2}$ In addition to disappearing from the population and adaptation, actors also have the potential to shape the selection environment. Lobbying, constructing political coalitions, public relations, and efforts to reshape culture are active strategies relevant for understanding the co-evolution of sociotechnical systems.
} 


\subsection{Accountability Tests and Legitimacy Flows of the Colorado Sage-Grouse Habitat Exchange}

Accountability relations are socially mediated assessments that structure flows of legitimacy and channel sociotechnical development. In reflecting on how declining populations of sage-grouse might give rise to changes in the Colorado energy sector, we can identify a set of important actions that allow us to reflect on how accountability relations and practices of legitimation are implicated in processes of social regulation. The analysis presented here is symmetrical. The aim is to highlight the potential for accountability relations to advance a sociotechnical dynamic that supports the sustainability of sage-grouse populations, and to highlight the potential for these same relations to legitimate and reproduce the sociotechnical dynamic responsible for the existing risk of extinction.

\subsubsection{Construction of a Market-based Habitat Exchange}

Applied to oil and gas extraction in Colorado and the fate of the sagegrouse, the construction of the habitat exchange is an important effort to introduce accountability for habitat loss and it is a key site of production of legitimacy for a range of actors. The exchange is promoted as capable of producing no-net loss of sage-grouse habitat. By quantifying the habitat losses associated with specific oil and gas development projects and the habitat gains associated with conservation actions by Colorado landowners interested in selling habitat credits, the exchange is a platform buying and selling sage-grouse habitat offsets. These offsets are a form of compensatory mitigation. As imagined by designers of the exchange, firms seeking drilling permits from the state purchase the appropriate volume of habitat credits through the exchange, and this makes it possible to advance oil and gas production while safeguarding sage-grouse populations. Compensatory mitigation of habitat loss is the final element of the mitigation hierarchy-avoid, minimise, and offset. The design and administration of the exchange emphasises offsetting as a fallback option. Avoiding development projects that degrade habitat and altering projects to minimise disturbance to habitat advance conservation directly, while offsetting can be understood as providing a more diffuse benefit to sage-grouse.

The Colorado Exchange was created by the Environmental Defense Fund (EDF), a New York-based NGO. EDF partnered with the Colorado 
Cattlemen's Association (representing landowners positioned to sell credits to oil and gas firms) and co-solicited relevant Colorado state agencies, and firms in the energy industry to participate in the creation and governance of the exchange (Large and Wolf 2018). The prospect of the sage-grouse gaining protection from the federal Fish and Wildlife Service through the ESA - and the political and economic fallout of regulation under the ESA - is generally understood as motivating this state-level cooperation. As a market-based approach to environmental management, habitat offsetting is linked to experience with the Clean Air Act, stream bank and wetlands mitigation banking, and the Clean Development Mechanism under the Kyoto Protocol. Reliance on market exchange to structure environmental management grants flexibility to individual firms, responds to criticisms of coercive bureaucratic controls, and ostensibly produces conservation at least aggregate cost. These traits lend habitat offsetting a modern and practical sensibility, which resonates positively with a broad range of relevant actors and varied logics of coordination.

Despite the elegance of the concept, after seven years of design and consultation, the exchange has not generated any habitat offsets. To repeat, the exchange has not supported any transactions that advanced conservation. Regardless of the capacity of the exchange to function, however, the concept of the exchange has produced a sustained dialogue among the central public and private sector policy actors in Colorado and nationwide.

Prospects for further development of the exchange were damaged in the summer of 2018 when the oil and gas industry formally announced that they were resigning from the exchange governance board and that they were not willing to play a further role in its development unless the expectations for offsetting were ratcheted downward. This announcement was followed by EDF shifting their personnel away from development of the exchange. The timing of this rupture was tightly linked to an announcement by the US Secretary of Interior ending mandates that supported compensatory mitigation under ESA. This policy decision was explicitly tied to ambitions to promote 'energy independence'. Over the past year, the Trump administration has continued to roll back legal protections for sage-grouse and, more broadly, to weaken ESA (Davenport/ NY Times 2019).

The habitat exchange was created to serve as a primary vehicle for holding the oil and gas industry accountable for sage-grouse habitat degradation, and it is a primary vehicle for demonstrating to federal regulators-and 
a wide variety of other parties - that ESA protections for sage-grouse are not necessary. The exchange continues to be represented as relevant and vibrant ${ }^{3}$ despite the fact that zero offsets have been created under this governance mechanism and the buyer of offsets has publicly announced their unwillingness to participate. Therefore, it seems reasonable to argue that the exchange serves to legitimate business as usual. The exchange functions to sustain the cognitive dissonance-that is, capacity to reconcile contradictions - attached to existing socioecological relations (Walker et al. 2009). The capacity of the exchange to organise and sustain dialogue in the policy field appears to be sufficient to maintain the legitimacy of existing socioecological relations. According to the co-evolutionary model sketched above (Fig. 8.1), there are no accountability tests and no selection pressure to advance structural or technical changes that could be recognised as a sustainability transition. That said, if a significant political bloc were to commit to conservation, and federal and state regulators were to reverse their position and require firms to purchase offsets (Green 2018), the exchange would be a critical element of the infrastructure supporting governance and sage-grouse conservation. In this sense, it is possible to interpret the exchange as all of the following: a failure, a distraction, and an accomplishment.

\subsubsection{Quantification Tools}

The technical core of the Colorado sage-grouse habitat exchange is the Habitat Quantification Tool (HQT) sage-grouse exchange. This habitat suitability model produces an integrated assessment of how site-specific land use/land cover changes affect the productivity of land for sage-grouse feeding, reproduction, nesting and fledging. HQT scores specify the magnitude of the habitat degradation (debits) associated with direct (e.g., oil and gas well pad and road and electricity service to the well) and indirect effects (e.g., spill overs from disturbed sites that degrade surrounding habitat values, measured through a distance-decay function) sage-grouse. The HQT also scores the positive contributions (credits) associated with conservation activities (e.g., ecological restoration, habitat enhancements,

\footnotetext{
${ }^{3}$ See, for instance, https://www.thepwc.org/habitat-exchangeexchange/ and https:// brianallmerradionetwork.wordpress.com/2018/12/21/12-21-18-co-governorhickenlooper-signs-executive-order-furthering-conservation-and-clarifying-mitigation-ofthe-greater-sage-grouse/.
} 
transfer of development rights). This quantification is the basis for asserting equivalencies across sites and projects, and it makes it possible to assign value and to conduct transactions through the exchange.

EDF convened a panel of scientific experts to produce the HQT, and there was an active effort to shield this process from political and economic considerations. The HQT was peer-reviewed by a committee under the auspices of the Ecological Society of America, as well as by a 3rd-party reviewer selected by the oil and gas industry. The process of creating a science-based routine for accounting of habitat values and to assign rights (credits) and responsibilities (debits) are key practices of accountability advanced by the exchange. The elaborate process through which debits and credits are assigned, and the performances of rigour associated with the algorithm, legitimates the exchange. In fact, habitat exchanges were developed in response to perceived shortcomings of existing models of offsetting based on 'conservation banking' (Toombs et al. 2018; Barral 2019). In conservation banking schemes, offsets are typically assigned based on ad hoc negotiations between administrators and buyers and sellers of credits/debits. There is typically no standardised biological modelling, and rights and responsibilities are not specified a priori. Additionally, offsets in habitat banking programmes have largely been financed by institutional investors engaged in a form of speculation, and there have been limited opportunities for local landowners to participate as suppliers of credits. The HQT responds to concerns about transparency, consistency, and access, which bolsters its legitimacy as a conservation mechanism. In terms of accountability, the HQT is a technical standard that quantifies rights and responsibilities. In terms of legitimacy, this standard presents opportunities for efficient assessment of the extent to which an energy project or firm has internalised a commitment to no-net loss of habitat.

In reflecting on the development and the current status of the exchange, it is worthwhile to note that mobilising science and making significant investments in a standardised, transparent, quantitative approach to assigning habitat values have not succeeded in advancing accountability applied to oil and gas firms' degradation of sage-grouse habitat. From a biological perspective, the sage-grouse does not cope well with disturbance, and this is reflected in the debits assigned by the HQT. A firm building a four-acre well pad in sage-grouse habitat can be assigned as much as 800 acres of offsetting responsibility. Since the HQT was unveiled, the oil and gas industry has consistently raised critical questions about the magnitude of the debits assigned to specific projects. The oil and gas industry has stated 
that they were willing to engage in offsetting, but not according to the terms embedded in the HQT. Ecological discipline can be transmitted through metrics, but power lies elsewhere.

\subsection{Advancing a Sustainable Energy Transition THAT SUPPORTS SAGE-GROUSE}

In reflecting on the Colorado Habitat Exchange as a vehicle to address conservation, it is worthwhile to reflect critically on the conflation of habitat conservation and security of the population of sage-grouse. It is quite possible for the population to collapse without a net loss of habitat. Climate change, invasive species, wildfire, and cumulative impacts from home building, road construction, infrastructure, recreation and other human activities, combined with questions about the fungibility of habitats, raise questions about the coherence of this approach to conservation. Bracketing these issues, these concluding remarks focus on exploring the value of a co-evolutionary perspective for institutional analysis and design.

According to the co-evolutionary model presented here, a transition to a state in which energy supply does not undermine the security of the sage-grouse population requires new accountability tests that derive from new conceptions and new practices of legitimacy. These tests must channel selection in a manner that drives change over time in the distribution of relevant land use behaviours. The change in behaviours derives from a shift in the population of actors and the operational procedures, competencies, and strategies of those actors. Under existing political-economic relations, the exchange is not capable of introducing the required discipline and/or rewarding relevant innovations.

Based on this analysis, research and practical interventions should focus on the potential for new politics and new dynamics in civil, market, and cultural domains that are capable of shifting how legitimacy is produced and accessed. With respect to accountability, there is a need to focus on sanctions (i.e., the imposition of costs and risks capable of reorienting behaviour and strategy). At present, the exchange does not work because there are no mechanisms to create demand for offsets through the exchange, premised on the HQT. Oil and gas firms are able to access drilling permits from the state through other, less stringent regulatory 
pathways. ${ }^{4}$ In the absence of leadership by the state - that is, willingness to impose sanctions on oil and gas firms that are heavy enough to change the extent of land use disturbance and sufficient to conserve sufficient and appropriately configured habitats- the exchange cannot function to conserve sage-grouse. Voluntary commitments by firms are insufficient and consumer preferences are not expressed in a manner capable of producing significant changes. Habitat offsetting, and perhaps most analogous market-based conservation strategies, rest on the existence or creation of demand for offsets. This demand rests on the legislative and judicial redefinition of rights and responsibilities. Unless consumers, investors, voters, and regulators hold these expectations and impose these duties, this environmental governance strategy cannot sustain sage-grouse in Colorado and advance a sustainable transition.

\section{REFERENCES}

Barral, S. (2019). Ecological and management dimensions of metric production in conservation banking. Journal of Rural Studies (In review).

Blühdorn, I. (2007). Sustaining the unsustainable: Symbolic politics and the politics of simulation. Environmental Politics, 16, 251-275.

Bovens, M. (2007). Analysing and assessing accountability: A conceptual framework. European Law Journal, 13(4), 447-468.

Copeland, H. E., Doherty, K. E., Naugle, D. E., Pocewicz, A., \& Kiesecker, J. M. (2009). Mapping oil and gas development potential in the US Intermountain West and estimating impacts to species. PloS one, 4(10), e7400.

Davenport/NY Times. (2019, March 15). Trump administration loosens sage grouse protections, benefiting oil companies. NY Times.

Green, M. (2018, July 27). The Hill. Retrieved May 2019, from https://thehill. $\mathrm{com} /$ policy/energy-environment/399262-administration-ending-rule-thatmade-industry-pay-for-damages-to

Habermas, J. (1975). Legitimation crisis. Boston: Beacon Press.

Kraft, B., \& Wolf, S. (2018). Through the lens of accountability: Analyzing legitimacy in environmental governance. Organization \& Environment, 31, 70-92. https://doi.org/10.1177/1086026616680682

Large, D., \& Wolf, S. (2018). How the endangered state acts: Reverse regulatory threat and market-based conservation policy (In preparation).

${ }^{4}$ Permits are awarded by the state through a process that involves attention to avoidance, minimisation and offsetting. Champions of the exchange argue that the terms of offsetting in these alternative forums are too generous to commercial interests, and this leads to underinvestment at all levels of the mitigation hierarchy. 
Norgaard, R. B. (1994). Development betrayed: The end of progress and a coevolutionary revisioning of the future. London and New York: Routledge.

Piketty, T. (2013). Capital in the twenty-first century. Boston: Harvard University Press.

Rockström, J., Steffen, W., Noone, K., Persson, A., Chapin, F. S., Lambin, E. F., ... Foley, J. A. (2009). A safe operating space for humanity. Nature, $461,472-475$.

Schroeder, M. A., Aldridge, C. L., Apa, A. D., Bohne, J. R., Braun, C. E., Bunnell, S. D., ... Hilliard, M. A. (2004). Distribution of sage-grouse in North America. The Condor, 106(2), 363-376.

Swyngedouw, E. (2009). The antinomies of the postpolitical: In search of a democratic politics of environmental protection. International Journal of Urban and Regional Research, 33 (3): 601-620(609).

Toombs, T. P., Sokulsky, J., \& Wolfe, D. W. (2018). Habitat exchanges: A case study of biodiversity offset design in the U.S. (In preparation).

USFWS. (2010). Endangered and threatened wildlife and plants; 12-month findings for petitions to list the greater sage-grouse (Centrocercus urophasianus). Washington, DC.

Walker, S., Brower, A., Stephens, R., \& Lee, W. (2009). Why bartering biodiversity fails. Conservation Letters, 2, 149-157.

Wolf, S., \& Bonanno, A. (Eds.). (2014). The Neoliberal regime in agri-food: Crisis, resilience and restructuring. London: Routledge/Earthscan.

Wolf, S. A., \& Primmer, E. (2006). Between incentives and action: A pilot study of biodiversity conservation competencies for multifunctional forest management in Finland. Society and Natural Resources, 19(9), 845-861. 
Open Access This chapter is licensed under the terms of the Creative Commons Attribution 4.0 International License (http://creativecommons.org/licenses/ by $/ 4.0 /$ ), which permits use, sharing, adaptation, distribution and reproduction in any medium or format, as long as you give appropriate credit to the original author(s) and the source, provide a link to the Creative Commons licence and indicate if changes were made.

The images or other third party material in this chapter are included in the chapter's Creative Commons licence, unless indicated otherwise in a credit line to the material. If material is not included in the chapter's Creative Commons licence and your intended use is not permitted by statutory regulation or exceeds the permitted use, you will need to obtain permission directly from the copyright holder.

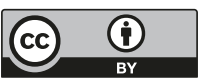


Conclusion 


\title{
Practices of Legitimation and Accountability Crises in a Range of Energy Transitions
}

\author{
Siddharth Sareen
}

\begin{abstract}
This chapter draws together five wide-ranging cases related to energy transitions. It articulates how practices of legitimation along four registers (discursive, bureaucratic, technocratic and financial) are present in each case to extents that differ based on how each author's choice of sector and focus modulates their relevance. This chapter summarises the ways in which these practices uphold and challenge accountability crises in each energy transition case. Such juxtaposition and consolidation allow discernment of cross-cutting dimensions along which practices of legitimation play out. These dimensions include spatiality, temporality, opportunism, prefiguration, performativity, power-play and normalisation or routinisation. The specification of practices of legitimation across cases sets up a concluding synthesis which links legitimation and energy transitions with broader environmental governance scholarship on accountability.
\end{abstract}

Keywords Legitimation • Energy transitions • Discursive • Bureaucratic • Technocratic • Financial

\footnotetext{
S. Sareen $(\bowtie)$

Department of Geography, Centre for Climate and Energy Transformation, University of Bergen, Bergen, Norway e-mail: Siddharth.Sareen@uib.no

(C) The Author(s) 2020

S. Sareen (ed.), Enabling Sustainable Energy Transitions, https://doi.org/10.1007/978-3-030-26891-6_9
} 


\subsection{The Cross-cutting Dimensions Where Legitimation Is Practised in Each Case}

What can be learned from summarising and consolidating the practices of legitimation encountered in the unpacking of five diverse energy transition cases? This chapter employs an abductive reasoning approach. The practices of legitimation that constitute the empirically informed point of departure in Chap. 2 are treated as an example of deductive reasoning here: it is possible to categorise practices along four registers (discursive, bureaucratic, technocratic and financial) that are overlapping (not mutually exclusive) and comprehensive (all practices of legitimation fit within their remit). These practices move from the general to the specific. The five cases that make up Chaps. 4, 5, 6, 7 and 8 hold examples of inductive reasoning. In each chapter, the author chooses a point of entry to offer a fine-grained analysis of accountability relations within their case of energy transition, moving from the specific to the general by means of analytical abstraction. Part III acknowledges that these analyses are limited by degrees of uncertainty - their knowledge base is necessarily incomplete. It seeks a pragmatic approach to characterise and inform decision-making despite uncertainty, and therefore applies abductive reasoning to settle upon the likeliest possible explanation in any given case.

In short, this concluding part works towards ways to characterise energy transitions as accountable to concerns of sustainability or not in disaggregated, case-specific instances of decision-making that affect decarbonisation and social equity enhancement outcomes. Accountability relations are rarely fully legible since they comprise both formal and informal practices of legitimation that require empirical study with varying data access, hence any approach that analyses accountability must address uncertainty within its design. An abductive approach to accountability analysis opens up for empirical investigation, accommodates uncertainty, and retains focus on practical applicability and real-world relevance.

Part III proceeds step-wise. This chapter articulates how practices of legitimation along four registers (discursive, bureaucratic, technocratic and financial) are present in each case to extents that differ based on how each author's choice of sector and focus modulates their relevance. It summarises the wide range of ways in which these practices uphold and challenge accountability crises in each energy transition case. Such juxtaposition and consolidation allow discernment of cross-cutting dimensions along which practices of legitimation play out. Proceeding sequentially 
through the five cases, it draws out seven dimensions: spatiality, temporality, opportunism, prefiguration, performativity, power-play, political economy, and normalisation or routinisation. This sets up the concluding Chap. 10, which links the four registers of practices of legitimation and the structuring set of cross-cutting dimensions with broader environmental governance scholarship on accountability.

While each case treatment can be read in multiple lights, certain dimensions stand out in each: spatiality and temporality in Timothy Moss' historical analysis of Berlin's energy transitions over the past century; opportunism in Christian Lund's study of attempts at the scalar reconstitution of authority during land conflicts in Indonesia; prefiguration and performativity in Håvard Haarstad's account of the role of target-setting in urban climate change mitigation efforts; power-play in the form of automobile incumbency, regime persistence and path dependence in Benjamin Sovacool's unpacking of electric mobility in the Nordic countries; and political economy and normalisation or routinisation in Steven Wolf's problematisation of the construction of a habitat exchange for biodiversity offsetting by energy extractive industries. The latter part of this chapter, Sect. 9.2, draws out these aspects case by case. It offers reflections in relation to which practices of legitimation play out within these dimensions and in what way.

\subsection{The Registers Along Which Legitimation Is Practised in Each Case}

\subsubsection{For Timothy Moss}

The case is three contrasting energy transitions at different historical moments in Berlin, each driven by the situated urges of a specific politics that evolves over time. Moss points out that there are different crises of accountability at each historical point, as the urban fabric of Berlin itself cannot be understood as the same space over the past century. In the 1920s, this concerned who should supply energy to Berlin; during postwar division, it concerned self-sufficiency for West Berlin's energy provision within city borders; and today it concerns ownership and control of the urban energy infrastructure. Each of these accountability crises features corresponding practices of legitimation, and this historical contextualisation (cf. Lockwood et al. 2017) serves to caution against any easy 
assumption of interventions that can render energy transitions accountable towards sustainable outcomes. Moss reminds us that sustainability itself is a relatively new concern in its current form, which came about during the 1970s. Drawing on earlier histories, he argues, requires acknowledgement of this limitation, but can generate a deeper appreciation of where sustainability thinking comes from, what echoes can be detected in the past, and how energy infrastructure legacies can frame current visions and enactments of sustainability. He points out the danger of committing to a certain configuration of accountability that over the course of evolving politics and institutional structures might come to constitute what Kramarz and Park (2017) call an accountability trap.

This case features a host of examples of discursive legitimation, for instance the local Communist Party's criticism of the regressive effects of tariff increases in the early 1930s, the protest camp against the planned power plant in the Spandau Forest in 1976 (Fig. 4.2), the campaign poster of the Berlin Energy Roundtable for a referendum in 2013 (Fig. 4.3), and energy security arguments used during the Cold War. It also draws out legitimation practices along the bureaucratic register, for instance through the municipal imposition of city-wide unitary utility tariffs and uniform service standards in the 1920s, and the Allies' insistence on high security standards for West Berlin's urban energy system, including three months' worth of primary energy reserves. Technocratic practices of legitimation are also in evidence in the large incumbent utility Vattenfall's contemporary emphasis on technical expertise and track record for managing the electricity and gas networks, and in cascading generating capacity requirements mandated during the security-oriented strategy during the Cold War. Finally, financial legitimation is visible in the pursuit of fair wages for employees at the city's utilities and improvements to service quality used to justify massive urban infrastructure investment (partly based on foreign debt finance) in the 1920s. It is, however, notable that the need for financial legitimation at the urban scale is absent during the Cold War years of high-cost energy security and West German government subsidies to Berlin.

Moss' historical analysis with its spatial and temporal purchase, then, offers rich insights into practices of legitimation along all four registers. Yet what is its import for interventions today in support of sustainable outcomes under transition? His analysis points to the articulation of demands for accountable remunicipalisation of energy infrastructure by contemporary social movements campaigning to prioritise decarbonisation 
and reduction in energy use over traditional criteria for urban energy management. This deconstruction and historical contextualisation of current trends that have brought about shifts in urban policy (in favour of a municipal utility and decarbonisation) is a demonstrably constructive outcome of accountability analysis, in that it provides an evidenced basis to inform in situ decision-making as well as to discuss and debate Berlin's energy transition at the present moment.

\subsubsection{For Christian Lund}

The case is changes in land use and in who has authority over land. This concern inevitably accompanies debates about energy transitions, as all energy sources have a land footprint, and most land use (in this case forestry or agriculture) has direct or indirect implications for greenhouse gas emissions or carbon sequestration. The questions of accountability that Lund unpacks, however, are chiefly concerned with power and social equity, and competition over the legitimation of power by institutions at different scales and with various degrees of formality. The accountability crises at play in Indonesia's hinterland are interrelated. On the one hand, there is the crisis of villagers who are being dispossessed of their land being hard put to hold a top-down state to account. The form of this state varies, as in 1978 when formal authority over large parts of land in West Java that was de facto used by agrarian villages shifted from the Provincial Forestry Service to the State Forest Corporation with uniformed parastatal police as part of an authoritarian regime. On the other hand, there is the crisis of what constitutes the state itself, with tussles over the scale at which authority is held. This surfaces in the villagers' recognition of the Sundanese Peasant's Movement in 2006, and more recently of the Village Office as the official local territorial administrative institution with authority over land, in order to counter the efforts of national institutions that sought to take over the land for forestry. Lund points out that the power to define subjecthood for oneself or to impose subjecthood on others is an integral part of accountability, and that this power is bidirectional (Fox 2018). Not only subjecthood, but also authority, can thus be re-purposed; making them visible in a given configuration here becomes the relational work of politics over land.

This case features instances of discursive legitimation such as the State Forest Corporation's announcement of a planting ceremony of 1,000 mahogany seedlings in rows named after government institutions (which the villagers promptly uprooted overnight), and its invocation of military 
terms such as 'illegal loggers' and 'subversive' to draw equivalence between the villagers' land occupation and organised crime. It also brings out specific bureaucratic legitimation practices, most notably the villagers' request (which was granted) for new ID cards from the Village Office as the official local territorial administration, which rendered their settlements official sub-villages within the territorial area claimed by the State Forest Corporation. Technocratic legitimation is also in evidence in the 1978 transfer of nearly one million hectares of official forestland in West Java to the State Forest Corporation-centralising authority away from the province-and in the latter's formal use of the language and protocols associated with national security to evict villagers as 'forest security disturbances'. Finally, practices of financial legitimation surface in the provisory system of payment $(10,000$ Rupiah per month) by villagers to the Sundanese Peasant's Movement instead of paying a third of their rice production as rent illegally demanded by the State Forest Corporation. They are also visible in the annual contributions of a million Rupiah by each sub-village to the Village Office, in essence a tax which established the villagers' claim as landholders.

Lund's fine-grained study of conflicts over land in remote tracts not only offers striking instances of practices of legitimation along all four registers, but also points to clear arenas that require attention for sustainable energy transitions. These arenas include the relations between people and institutions at multiple scales, and the necessity to allow for the desire for change to express itself in democratic politics. In his case, both the top-down use of force and popular resistance are opportunistic. Each seeks to recognise and establish specific relations between people and institutions in order to cement land claims in their favour. This reading of the shaping of accountability relations casts new light on the social contract and on authority and subjecthood.

\subsubsection{For Håvard Haarstad}

The case is how Norwegian cities set climate mitigation targets construed as reductions in carbon emissions at the urban scale. While these targets are seemingly ambitious and commendable, they encounter challenges of commensurability across cities, and often lack concrete strategies for operationalisation. Haarstad identifies an accountability crisis that the very presence of decarbonisation targets can serve to justify prolonged delay on actual climate mitigation, as targets allow cities to channel the discursive 
power of the promise of laudable action at the expense of diffusing political pressure over the urgency of substantive action to achieve these goals which remains both slow and insufficient. Yet he flips this to point out that target-setting itself is not only performative but can also be regarded as a form of prefigurative politics, whereby the apparent failure to meet targets that increasingly come to be seen as desirable can spark another accountability crisis, one that can drive necessary climate mitigation at the urban scale. The Zero Growth Objective for urban transport in Norway, argues Haarstad, has resulted in concrete agreements signed by its largest cities in 2016 and 2017 that have not only committed to limit traffic but also delivered results by way of a reduction in private car traffic during 2018 . Contra the techno-managerial apparatus of the post-political condition (Swyngedouw 2010) that simply supports the status quo, the carrying power of numbers may motivate action by working targets into routinised repertoires.

This case offers a slew of examples of discursive legitimation, starting with the White Paper on Norwegian Climate Policy from 2006 which articulated the need for a shift to public and non-motorised transport, the White Paper on Norwegian Climate Policy from 2012 which formulated this as a 'goal' or target, and the very statement of the Zero Growth Objective. This posits that all growth in personal traffic in Norway's largest cities must be covered by public or non-motorised transport. Bureaucratic legitimation is also at play given that these and other government policies (such as the Climate Accord of 2008 in the Norwegian parliament) consistently reference a $2{ }^{\circ} \mathrm{C}$ target to limit global warming and have worked this into a broad range of national policy documents and strategies, including for urban transport in this specific case. The use of technocratic practices of legitimation is evident in the National Transport Plan Working Group's reasoning that 'zero' is a very easy target to measure and thus useful in holding cities to account, and the subsequent agreements signed by the country's largest cities with specific indicators to measure performance on urban car traffic. Crucially, financial legitimation accompanies the Zero Growth Objective through these Urban Environment Agreements, which tie the amount of central funding allocated to cities for local transport infrastructure with their prowess in meeting the target.

Haarstad thus constructs the use of metrics as more than simply a bureaucratic apparatus of governance that perpetuates accountability crises in the shiny guise of new mitigation targets. He argues that targets 
perform work that helps enable sustainable energy transitions by working their way into specific policies and indicators within sectors such as transport. They drive future priorities by linking them to concrete objectives that can be measured (zero growth) and punished or rewarded (through urban transport infrastructure budget allocation). This relational analysis of policy-making and the operationalisation of targets highlights the value of prefigurative politics. Accountability analysis of this case contributes a valuable reconsideration of the role of targets in legitimating gradual but incremental climate mitigation action. Rather than challenging the existing sectoral configuration outright, targets work performatively to reorient its workings through the very routine, normalised structures and processes that shape sectoral futures.

\subsubsection{For Benjamin Sovacool}

The case is the advent of electric mobility in the five Nordic countries. As power from the electric grid is based on renewable energy to large extents in these contexts, this shift from fossil fuel powered vehicles to grid charged ones constitutes a prima facie energy transition. But Sovacool's analysis of electric vehicle roll-out problematises this assumption, and flags four crises of accountability. The first concerns inequitable access to electric vehicles, which so far largely remain the preserve of privileged people even in these relatively wealthy countries. The second points out that exclusion is reflected in national planning around electric mobility, which risks making people dependent on distant infrastructures (like electric charging stations) on terms beyond their democratic control. The third crisis is on multiple spatial scales and pertains to the creation of externalities at remote sites of material extraction to build electric vehicles, as well as the risk of relocating pollution from cities to regional sites of electric power production. The fourth crisis features the burden on some sectoral stakeholders such as fuelling stations that might have to invest in costly charging station infrastructure or risk job loss and vehicle dealerships that might have to invest more time and effort into electric vehicle sales. Sovacool argues that these crises, while perhaps inevitable components of shifting sectoral regimes, stem from the uneven effects of transition dynamics on different actors, and from inequities that are deeply embedded within existing systems of mobility.

This case draws out a host of instances of discursive legitimation, most notably from people challenging the roll-out of electric vehicles in terms 
of its sustainability effects. These interviewees critique subsidies accorded to Teslas as luxury electric vehicles; equate this to 30,000 public transport tickets per beneficiary; are sceptical of hybrid vehicles as allowing owners to cash in on incentives without affording any means to monitor their actual usage of electricity rather than internal combustion engines; and are critical of political tokenism in public discourse around electric vehicles. Bureaucratic legitimation is evident to varying extents across Nordic countries, from Norway's all-inclusive packages to incentivise electric vehicles (which are so far mainly cars) to Denmark's reluctant extension of lower duties ( $40 \%$ instead of $150 \%$ ) on electric cars, but by comparison comes far less into play in relation to the electrification of public transport. Practices of technocratic legitimation are presented generically to promote sustainable mobility through charging at off-peak times, mandating battery recycling to reduce externalities, emphasising the decarbonisation of electric grids and coordinating roll-out with planning that prioritises nonmotorised transport forms and intermodal electric transport. Finally, financial legitimation is notable in the enormous support provided for private electric cars which has been used by relatively rich people, and in the absence of similarly strong support to rapidly build out public electric transport infrastructure or cushion vulnerable groups against regressive effects of national fiscal policies on electric mobility (for instance through free public transport).

Sovacool thus illustrates practices of legitimation along all four registers, drawing on a large body of empirical material to characterise the multi-sited, multi-scalar and polycentric nature of accountability relations in mobility systems under transition. His case surfaces instructive principles (Tables 7.2 and 7.3) across comparative country contexts (Table 7.1) for how to work towards sustainable energy transitions in electrifying mobility systems. Treatment underscores the importance of unpacking power-play to fathom automobile incumbency, regime persistence and path dependence. By studying the practices of legitimation that accompany shifts to electric mobility, accountability analysis brings several crises to the fore. It provides a means to point out specific measures that can be undertaken in each context to overcome these crises.

\subsubsection{For Steven Wolf}

The case is the construction of a habitat exchange market that could enable habitat replacement for biodiversity conservation of the sage-grouse 
(an endangered ground nesting bird that depends on sage brush steppe habitat) in Colorado while permitting the expansion of energy extractive industries. On the one hand, this can be regarded as a complete nonstarter, as Wolf points out that over the course of seven years, the habitat exchange failed to record a single transaction-an apparent accountability crisis in that it fails to address sage-grouse population decline. He attributes this to the lack of appetite of the oil and gas companies to stump up the expenses for the amount of scientifically requisite land to compensate for the loss of biodiversity habitat, and inadequate political will to force their hand. On the other hand, as the process unfolds, it does construct the numerical model informed by cross-sectoral concerns (land costs and requirements for the fossil fuel majors and sage-grouse habitats respectively). Wolf argues that this is a step in the direction of accountable socioecological regulation, as it has brought into being an accountability test. Given a different future political economic context, the very existence of this data infrastructure (the Habitat Quantification Tool) and market infrastructure (the Colorado Habitat Exchange) increases its likelihood of eventual insertion into pertinent bureaucratic routines, and normalisation into decision-making around land allocation and habitat exchange.

This case draws out numerous instances of discursive legitimation, including the United States federal administration's explicit linkage of 'energy independence' with its ending of mandatory compensatory mitigation under the Endangered Species Act in 2018, and the continued representation of the habitat exchange as relevant and vibrant despite its never having executed a single transaction. Ironically, the habitat exchange was instrumental in arguments against protecting sage-grouse populations under the Endangered Species Act. Practices of bureaucratic legitimation are visible in the non-governmental organisation Environmental Defense's efforts to set up the Colorado Habitat Exchange and orchestrate participation in its creation and governance by various relevant actors (including a cattlemen association, state agencies and energy extractive industries), layering this effort on experience with habitat offsetting under the Clean Air Act and the Kyoto Protocol's Clean Development Mechanism. Technocratic legitimation in this case pertains to the strategy of championing a market mechanism to avoid critique of coercive bureaucracy and to benefit from efficiencies such as low transaction costs, and to associated innovations such as the Habitat Quantification Tool to calculate compensation amounts for replacement of sage-grouse habitats. Financial legitimation, while present in the very logic of a market mechanism for carbon 
offsetting of habitat loss, remained absent in practice. As the subject of controversy when the oil and gas industry protested the debits assigned to them based on the modelled cost calculations, as also when it resigned from the exchange's governance board, questions of finance were used to delegitimate the whole exercise.

Wolf articulates accountability relations as a hollow performance in his case, where practices of legitimation along the four registers serve to perpetuate a crisis of accountability. He emphasises that what remains missing is sanction, an imposition of requirements that would drive demand for offsets, even when the calculation and market infrastructure are put in place. These latter developments represent the innovation of mechanisms that can be used to routinise and normalise accountability if society manifests the political economic will to demand a sustainable energy transition that must necessarily support sage-grouse as well. Thus, accountability analysis enables a clear account of what remains lacking to render this energy transition case sustainable.

\section{REFERENCES}

Fox, J. (2018). The political construction of accountability keywords. IDS Bulletin, $49(2), 65-80$.

Kramarz, T., \& Park, S. (2017). Introduction: The politics of environmental accountability. Review of Policy Research, 34(1), 1-4.

Lockwood, M., Kuzemko, C., Mitchell, C., \& Hoggett, R. (2017). Historical institutionalism and the politics of sustainable energy transitions: A research agenda. Environment and Planning C: Politics and Space, 35(2), 312-333.

Swyngedouw, E. (2010). Apocalypse forever? Post-political populism and the spectre of climate change. Theory, Culture \& Society, 27, 213-232. 
Open Access This chapter is licensed under the terms of the Creative Commons Attribution 4.0 International License (http://creativecommons.org/licenses/ by $/ 4.0 /$ ), which permits use, sharing, adaptation, distribution and reproduction in any medium or format, as long as you give appropriate credit to the original author(s) and the source, provide a link to the Creative Commons licence and indicate if changes were made.

The images or other third party material in this chapter are included in the chapter's Creative Commons licence, unless indicated otherwise in a credit line to the material. If material is not included in the chapter's Creative Commons licence and your intended use is not permitted by statutory regulation or exceeds the permitted use, you will need to obtain permission directly from the copyright holder.

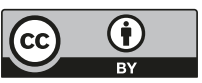




\title{
Conclusion: Legitimation and Accountability in Energy Transitions Research
}

\author{
Siddharth Sareen, Timothy Moss, Christian Lund, \\ Hàvard Haarstad, Benjamin Sovacool, and Steven Wolf
}

Abstract This concluding synthesis argues that practices of legitimation can empirically deconstruct any given energy transitions case to identify

S. Sareen $(\bowtie) \bullet$ H. Haarstad

Department of Geography, Centre for Climate and Energy Transformation, University of Bergen, Bergen, Norway

e-mail: Siddharth.Sareen@uib.no; Havard.Haarstad@uib.no

T. Moss

Integrative Research Institute on Transformations of Human-Environment Systems (IRI THESys), Humboldt University of Berlin, Berlin, Germany e-mail: timothy.moss@hu-berlin.de

C. Lund

Department of Food and Resource Economics, University of Copenhagen,

Copenhagen, Denmark

e-mail: clund@ifro.ku.dk

B. Sovacool

Science Policy Research Unit, University of Sussex, Falmer, UK

e-mail: b.sovacool@sussex.ac.uk

S. Wolf

Department of Natural Resources, Cornell University, Ithaca, NY, USA

e-mail: saw44@cornell.edu

(C) The Author(s) 2020

S. Sareen (ed.), Enabling Sustainable Energy Transitions, https://doi.org/10.1007/978-3-030-26891-6_10 
mechanisms that constrain or enable accountability to decarbonisation with social equity enhancement. The versatile analytical application of these practices can advance environmental governance research on steering energy transitions towards sustainability. This chapter explicates seven cross-cutting dimensions and indicates how practices of legitimation play out within them in five cases related to energy transitions, drawing on contextualised examples from two cases for each dimension. This illustrates how practices of legitimation (discursive, bureaucratic, technocratic and financial) can reframe wide-ranging cases from diverse perspectives, fields and disciplines. Applied researchers can choose customised dimensions and enlarge this indicative set to identify situated mechanisms that modulate accountable energy transitions.

Keywords Accountability • Governance $\bullet$ Legitimacy $\bullet$ Energy transitions $\bullet$ Sustainability

What is the collective takeaway from our exploratory analysis centred on accountability? Defined as accountability to decarbonisation with enhanced social equity, the concept is analytically generative for characterising components of any given energy transition as contributing to sustainability or not. Operationalised as four registers of practices of legitimation, accountability can be profitably applied across a wide range of cases. This application can emphasise specific cross-cutting dimensions based on which accountability relations are of contextual interest. The five cases highlight grounded practices of legitimation, whether discursive, bureaucratic, technocratic or financial, that relationally produce accountability. The dimensions that surface in these cases link accountability with other environmental governance concepts that are useful for advancing critical analyses of energy transitions. While provisional, this synthesis constitutes a basis that future research is invited to adapt and employ.

Section 10.1 furnishes a brief description of each of the seven indicative dimensions that are embodied in the five cases related to energy transitions in this book. Using illustrative examples from two cases for each of these dimensions, Sect. 10.2 demonstrates how practices of legitimation can be applied within each dimension. Finally, Sect. 10.3 summarises the 
significance of the five cases for future environmental governance scholarship on accountability in energy transitions.

\subsection{Accountability, Registers, Cross-cutting Dimensions and Practices of Legitimation}

Analyses focused on accountability relations can demonstrably construe a wide variety of cases in energy transition terms and pinpoint a range of accountability crises. Such reframing can help articulate how specific accountability crises are being maintained or challenged through practices of legitimation along registers of discourse, bureaucracy, technocracy and finance. This book has presented and consolidated a variety of case treatments-historical, conflict-centred, comparative, multi-scalar and crosssectoral. This foray has surfaced a number of cross-cutting dimensions. Sareen (2019a) argues in Chap. 9 that our case studies span and equip us to discern seven indicative dimensions that can serve to structure our insights and guide future application. Within each such dimension, it is possible to identify practices of legitimation that are at work to contest, uphold or produce new specific outcomes in relation to accountable energy transitions.

Table 10.1 plots the registers along which the practices of legitimation play out against each of the cross-cutting dimensions that come up due to case selection and approach, which are choices guided by analysts' contextual knowledge. This makes the practices of legitimation pliable and oriented at situated analyses of accountability. They can inform interdisciplinary analysis and identify interventions that can enable sustainable outcomes

Table 10.1 Practices of legitimation with indicative dimensions for five wideranging cases

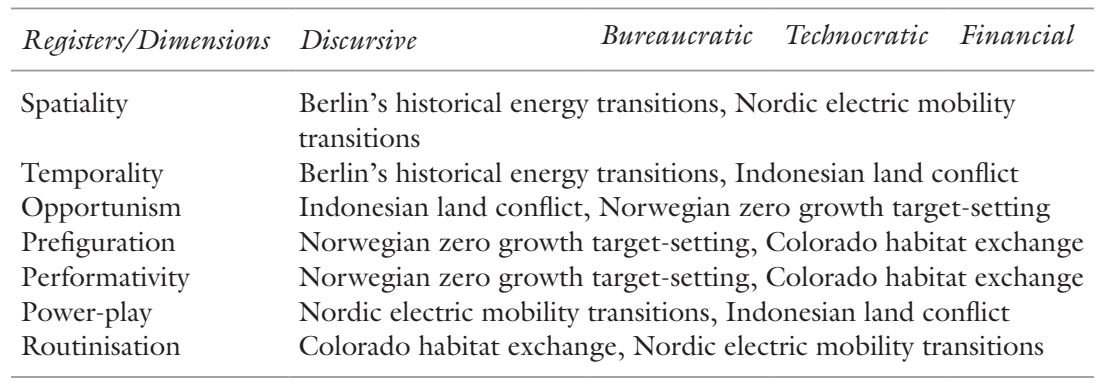


during energy transitions in a given context. The four registers along which legitimation is practised-discursive, bureaucratic, technocratic and financial - play out within each dimension represented in the rows. These dimensions include spatiality, temporality, opportunism, prefiguration, performativity, power-play and routinisation (or normalisation). The table indicates two main cases which concern each dimension, but aspects certainly surface in other cases as well. The dimensions structure our description of how practices of legitimation can be applied to analyse accountability in energy transitions governance. Despite the wide range of these five cases, future work along these lines will doubtless generate additional dimensions. Whereas the four registers along which legitimation is practised are elaborated in Chap. 2 (Sareen 2019b), the cross-cutting dimensions are explicated below with summary reflections on how each one manifests in two of the five cases.

\subsubsection{Spatiality}

Legitimation plays out simultaneously at and across multiple spatial scales during an energy transition. At stake are questions of distribution-where are benefits and burdens relocated from any sectoral changes, where are winners and losers based-and of the locus of decision-making and the sites that it affects across the spatial scale. In Berlin's historical energy transitions case, the spatial dimension appears pertaining to where energy is generated, where energy infrastructure is financed and where energy infrastructure is controlled and owned. This varies in relation to Berlin's territorial boundaries as well as the political economy of its geographical context. In the Nordic electric mobility transitions case, the spatial dimension relates to material decoupling in terms of where energy is produced to power the electric grid and where vehicles are manufactured. It also relates to where energy infrastructure like charging stations comes up, which jobs this creates and displaces, and what siting implies for which actors control electric mobility. Similar multi-scalar issues come up concerning material inputs (such as cobalt and lithium) as well as waste flows (especially electronic waste).

\subsubsection{Temporality}

Legitimation plays out differently over time, both during the same energy transition and during sequential ones. The temporal dimension directs 
attention to how sociotechnical and political economic configurations evolve within the same spatial context. This concentrates power at different spatial scales and makes different societal choices politically viable. It opens up new technological possibilities through arenas of innovation where timing and concomitant infrastructural investment dynamically determine energy futures. In Berlin's historical energy transitions case, these transitions are refracted by changing mores of political pressure interwoven with societal expectations and the material evolution of energy infrastructure. This includes the intergenerational equity aspects that underpin current campaigns to climate-proof Berlin's energy infrastructure. In the Indonesian land conflict case, citizens squeezed off their land by an authoritarian regime are forced to adopt new tactics to retain land control over time. This brings about new competing recognition of institutional authority by subjects. They seek to strengthen the state at the local scale where it is more responsive to their needs, creating new governmental configurations over time.

\subsubsection{Opportunism}

Legitimation plays out in powerful ways at specific conjunctures that can be definitive for a given energy transition. These moments of rupture or leverage points can be understood through the cross-cutting dimension of opportunism. Opportunistic or ad hoc legitimation capitalises on a circumstantial opening to wrest control of new possibilities and establish them in sociomaterial form through informal but rapidly formalised means rather than through existing formulae or behavioural patterns. It thus constitutes a quantum change in how society is configured with regard to a particular energy transition. In the Indonesian land conflict case, West Javanese villagers exercise their right to pay rent with discretion, recognising a local authority in the form of the Village Office rather than the central government. This in turn shapes relations of authority in favour of their recognition as landholders. In the Norwegian zero growth targetsetting case, a global $2{ }^{\circ} \mathrm{C}$ climate mitigation target is translated into a Zero Growth Objective to limit car traffic.

\subsubsection{Prefiguration}

Legitimation plays out in premeditated ways, where actors strategically manoeuvre energy transitions to secure advantageous new sectoral 
configurations. In contrast to opportunism, the dimension of prefiguration highlights how particular choices are orchestrated and made seemingly inevitable, despite having been initiated in a circumstance where they were highly contingent. This dimension enables us to trace how specific pathways are brought into being out of a wide array of possibilities. In the Norwegian zero growth target-setting case, setting a highly ambitious target that curbs any future increase in car traffic in Norway's largest cities puts a literal brake on this hitherto growing sectoral segment within a short span. In the Colorado case, the failed attempt to secure habitat replacement for the sage-grouse from land takeover by energy extractive industries nevertheless creates infrastructures for data (Habitat Quantification Tool) and markets (Colorado Habitat Exchange) for future habitat exchange.

\subsubsection{Performativity}

Legitimation plays out as farce that can risk perpetuating the status quo and supporting energy transitions that lead to unsustainable outcomes, for instance decarbonising without enhancing social equity. The dimension of performativity draws attention to this tendency of employing rhetoric to obfuscate the absence of sufficient substantive action. Legitimation can thus become a clever and attractive but ultimately hollow performance, where new accountability relations to transition in a sustainable manner are not shaped for a different energy future, despite fanfare. In the Norwegian zero growth target-setting case, the Zero Growth Objective can be read as an ambitious target that, without a slew of accompanying sectoral policies, would simply remain unattainable; more critically, it could be argued as a means of distracting attention away from the carbonemitting aviation sector which continues to grow. In the Colorado case, the expectation that a habitat exchange market would work (despite its subsequent failure) is implicated in the removal of compensatory mitigation mandates stemming from the Endangered Species Act.

\subsubsection{Power-play}

Legitimation plays out in uneven topographies of power, where outcomes are not shaped in a vacuum of fair decision-making processes, but socially modulated by influential actors within evolving institutional structures with specific historical legacies. The dimension of power-play highlights 
the role of both inequitable power relations and more structural factors such as path dependency and regime persistence during energy transitions. It directs attention not only to overt confrontation and contestation but also to the absence of important deliberations where power grabs or incumbency prematurely close particular energy futures. In the Nordic electric mobility transitions case, the automobility regime and existing biases of systems of mobility are reproduced in the roll-out of electric mobility to a greater extent than the adoption of public and non-motorised transport solutions. In the Indonesian land conflict case, West Javanese villagers are unable to even consider recourse to authority at the national scale for their marginalised concerns and resort to the local scale.

\subsubsection{Routinisation}

Legitimation plays out through enactment within the existing sociopolitical fabric, at times achieving incremental change with greater ease and effectiveness than through more disruptive attempts at energy transitions. Through routinisation or normalisation, practices of legitimation work their way into the bureaucratic and banal decision-making apparatus of existing, often powerful institutions. Rather than subjecting these institutions themselves to scrutiny, such legitimation reorients and repurposes their internal functioning. In the Colorado case, the choice of a habitat exchange is seen as a workable middle ground that can plausibly bring energy extractive industries on board in a politically feasible and efficient manner to replace sage-grouse habitats and conserve the declining population; Environmental Defense focuses its efforts not on protesting fossil fuels but on assembling requisite data and market infrastructure. In the Nordic electric mobility transitions case, while the roll-out of electric mobility might suffer from existing problems of mobility systems, policies to encourage and coordinate it have made the Nordic countries global front-runners in electric mobility adoption.

\subsection{Applying Practices of Legitimation Across Registers AND Dimensions}

Having defined the dimensions, the next section illustrates how the registers along which legitimation is practised can be applied within each dimension. We draw on the five cases whose practices of legitimation have 
been deconstructed and consolidated in Chap. 9 (Sareen 2019a). As illustrated above, multiple cases feature legitimation within each dimension; for clarity, we only present practices from two cases for each dimension.

\subsubsection{The Spatiality Dimension}

Within this dimension, discursive legitimation plays out at specific sites in situated ways, with consequences for what kind of energy transition is legitimated. In Berlin's historical energy transitions case, discursive legitimation appears spatially in the use of energy security arguments during the Cold War to push for self-sufficient energy production within city limit. It is also illustrated by the protest camp against the planned power plant in the Spandau Forest in 1976 (Fig. 4.2), which signifies contested territorialisation under energy transition. In the Nordic electric mobility transitions case, spatiality is implicit in people's critique of subsidies for luxury electric cars, which are equated with 30,000 transport tickets for each beneficiary, drawing attention to the spatial concentration of privilege and elitism, and its equity effects during transitioning mobility systems.

Bureaucratic legitimation is spatially expressed in the Berlin case as the municipal imposition of city-wide unitary tariffs across utilities and uniform service standards in the 1920s. This constitutes a smoothening and unification of urban territory for energy service delivery. Technocratic legitimation manifests spatially in the same case: the large incumbent utility Vattenfall's contemporary emphasis on technical expertise and track record for managing electricity and gas networks is a mode of ensuring continued relevance for actors with large spatial coverage, despite sectoral shifts towards openness to new small-scale actors. Financial legitimation also operates spatially in this case, as revealed in the adoption of city-wide fair and equal sectoral employee wages and service quality improvements to justify massive urban infrastructure investment (partly financed through foreign debt) in 1920s Berlin.

\subsubsection{The Temporality Dimension}

Here, discursive legitimation shows temporal significance in the Berlin case, pinpointed as discursive shifts from criticism of the regressive effects of tariff increases (by the local Communist Party during the 1920s) to a distinct emphasis on ownership in the campaign poster of the Berlin Energy Roundtable in 2013 (Fig. 4.3 shows this proclaiming 'Our 
municipal utility, our power grid, our Berlin' for a referendum). Priorities and their discursive justification change over time in ways that reveal an evolving basis for accountability claims. Bureaucratic legitimation also makes sense of temporal patterns such as in the Berlin case with high security standards built into the urban energy system in the 1970s, including three months' worth of primary energy reserves. This artefact of geopolitics has temporal legacies that shape subsequent energy infrastructure.

Technocratic legitimation exhibits a temporal dimension in the same case with Berlin's requirements for cascading generating capacity during the security-oriented strategy of the 1970s. These embed particular protocols into energy infrastructure that extend into current sectoral standards. In the Indonesian land conflict case, the transfer of nearly one million hectares of official forestland in West Java to the State Forest Corporation in 1978 centralises authority away from the province in a manner that gains significance during land ownership conflicts three decades later. Financial legitimation expresses temporally as a highlighted singularity in the Berlin case where, in contrast to urban politics shaping energy infrastructure investments, financing simply did not require validation at the urban scale during the Cold War years of prioritised energy security and West German government subsidies to Berlin.

\subsubsection{The Opportunism Dimension}

Within this dimension, discursive legitimation comes into play in the Indonesian land conflict case when the State Forest Corporation announces a planting ceremony of 1000 mahogany seedlings in rows named after government institutions, as well as when the villagers promptly uproot them overnight, both channelling the occasion into the purposive reframing of where authority rests, through imposition and resistance. Bureaucratic legitimation is notable within this dimension in the same case when the villagers request (and are granted) new ID cards from the Village Office as the local territorial administration, which renders their settlements official sub-villages in the territorial area claimed by the State Forest Corporation.

Technocratic legitimation exhibits an opportunistic dimension in the Norwegian zero growth target-setting case, when the National Transport Plan Working Group reasons that 'zero' is a very easy target to measure and thus useful in holding cities to account, and in subsequent agreements signed by Norway's largest cities with indicators to track performance on 
urban car traffic. Financial legitimation comes up in the Indonesian land conflict case by way of the provisory system of payment by villagers to the Sundanese Peasant's Movement, rather than paying rent illegally demanded by the State Forest Corporation. It is also present in each sub-village's annual contributions to the Village Office, in essence embodying a land tax to establish the villagers' claim as landholders.

\subsubsection{The Prefiguration Dimension}

Here, discursive legitimation is apparent in the Norwegian zero growth target-setting case, where the White Paper on Norwegian Climate Policy 2006 articulates the need for a shift to public and non-motorised transport, the White Paper on Norwegian Climate Policy 2012 formulates this as a 'goal' or target, and the Zero Growth Objective states that all growth in personal traffic in Norway's largest cities must come through public or non-motorised transport. Bureaucratic legitimation also takes on a prefigurative dimension in the same case, where Norway's policies (such as the Climate Accord of 2008) consistently reference a $2^{\circ} \mathrm{C}$ target to limit global warming and work this into a range of national documents and strategies, including for urban transport. This imbrication of a broad goal into concrete policies firms up the possibility of a stronger basis for ambitious energy transitions in urban mobility.

Technocratic legitimation is instantiated as prefigurative in the Colorado habitat exchange case in the innovation of the Habitat Quantification Tool, which can calculate compensation amounts for replacement of sagegrouse habitats. This paves the path for biodiversity conservation mechanisms in circumstances of greater political will. Financial legitimation is evidently prefigurative in the Norwegian target-setting case, where the Urban Environment Agreements under the Zero Growth Objective tie the central funding allocated to cities for local transport infrastructure with their prowess in meeting the target. This linkage moves future incentives for the sectoral evolution of urban mobility into closer alignment with accountability to sustainable energy transition targets.

\subsubsection{The Performativity Dimension}

Within this dimension, discursive legitimation is evident in the Colorado case, where the state habitat exchange was represented as relevant and vibrant despite never recording any transactions, and was used to argue 
against protecting the sage-grouse under a federal Endangered Species Act. The habitat exchange served as a mechanism to perform and uphold hollow accountability without changing substantive relations on the ground. Bureaucratic legitimation plays a performative role in the Norwegian case, where Norway's policies consistently reference a $2{ }^{\circ} \mathrm{C}$ target to limit global warming and have worked this into a range of national documents and strategies; this can also be seen as prefigurative in Sub-Sect. 10.2.4.

Technocratic legitimation is at work within the performative dimension in the Colorado case in terms of the strategy of championing a market mechanism to circumvent critique of coercive bureaucracy and benefit from efficiencies like low transaction costs. This strategy brings the Habitat Exchange and Habitat Quantification Tool into being. Financial legitimation is performative in the same case: questions of finance are used to delegitimate the whole exercise as the subject of controversy when the oil and gas industry protests the debits assigned to them based on the modelled cost calculations, as well as when it resigns from the governance board of the habitat exchange.

\subsubsection{The Power-play Dimension}

Here, discursive legitimation is in evidence in the Nordic electric mobility transition case. People's scepticism about hybrid vehicles surfaces in concerns that these allow their owners to cash in on incentives (for adopting low-emission vehicles) without affording the means to monitor their actual usage of electricity rather than the internal combustion engines. In the Indonesian land conflict case, the State Forest Corporation invokes military terms such as 'illegal loggers' and 'subversive' to draw equivalence between the villagers' land occupation and organised crime, another instance of power-play through discursive delegitimation. Bureaucratic legitimation operates as power-play in the Nordic case, when Norway offers all-inclusive incentive packages and Denmark maintains lower duties ( $40 \%$ instead of $150 \%$ ) for electric vehicles, but incentive schemes to electrify public transport remain far less substantial.

Technocratic legitimation manifests within the power-play dimension in the Indonesian land conflict case, where the State Forest Corporation uses the formal characterisation and protocols associated with national security to evict villagers as 'forest security disturbances'. This legitimation allows the state to levy its might against claim-making subjects. Financial 
legitimation embodies power-play in the Nordic electric mobility transitions case. Enormous support is provided for private electric cars used by relatively rich people, without similarly strong support to rapidly build out public electric transport infrastructure or cushion vulnerable groups against the regressive effects of fiscal policies on electric mobility.

\subsubsection{The Routinisation Dimension}

Within this dimension, discursive legitimation is in evidence in the Colorado habitat exchange case. The federal administration puts an end to mandatory compensatory mitigation by drawing explicit links with energy independence to make energy extraction an issue of national security. In the Nordic electric mobility transition case, protest against discursive legitimation to routinise inequitable transition surfaces as people's critique of political tokenism in public discourse around electric vehicles. Bureaucratic legitimation is expressed as routinisation in the Colorado case, where efforts by Environmental Defense, layered upon prior experiences with habitat offsets, orchestrate participation in the creation and governance of the Colorado Habitat Exchange by various relevant actors.

Technocratic legitimation appears as routinisation in the Nordic case, which identifies dynamics such as promoting off-peak charging, mandating battery recycling to reduce externalities, emphasising the decarbonisation of electric grids and coordinating electric vehicle roll-out with prioritised non-motorised and intermodal electric transport. Financial legitimation manifests as routinisation in the Colorado habitat exchange case. Finance remains absent in practice, but present in the very logic of markets as mechanisms for the efficient implementation of accountability on which the market-based offsetting of habitat loss is premised.

\subsection{Environmental Governance Research on Accountability in Energy Transitions}

Not all cases of energy transition necessarily feature practices of legitimation across all dimensions. The dimensions are partly an artefact of each author's strategically chosen focus and partly reflect data availability. Thinking in terms of accountability and legitimation does not supplant other methods and common sense, but rather offers diagnostic value. It is purposely pliable; the dimensions are overlapping, not mutually exclusive, 
nor comprehensive. Applied researchers and analytically oriented practitioners can apply the practices of legitimation to fit situated needs, mobilising the four registers within strategic dimensions of their choice. This analytical approach to accountability is based in abductive reasoning to settle upon the likeliest possible explanation in any given case of energy transition and pragmatically inform decision-making despite uncertainty. Such analysis can characterise disaggregated components of any energy transition case as accountable to concerns of sustainability or not. Scientifically evidencing both the formal and informal practices of legitimation that are at work during energy transitions can aid decision-making towards outcomes that decarbonise and enhance social equity. This approach can thus combine analytical rigour with practical applicability and real-world relevance.

The five cases in this book show that energy transitions are many things and involve not only changing energy sectors but also cognate sectors such as land, forest, transport, biodiversity, markets and political economies of multi-scalar contexts. Our practically oriented vision of enabling accountable governance for sustainable energy transitions represents a programmatic task across many sectors. To inform practical decision-making of various energy transitions and their constituent parts in contextually informed and responsive ways, applied researchers can operationalise an accountability-based approach in their respective fields within broader environmental governance scholarship. Their domain knowledge and disciplinary sensibilities will help them customise this approach to suit their purposes.

The illustrations in this book aim to aid such intellectual uptake and cross-fertilisation, and thus pave the path for situated efforts to study practices of legitimation. To demonstrate the generative potential of an accountability-based analytical approach to energy transitions governance, we offer closing reflections by working sequentially outward from the five cases.

In the Berlin case, Timothy Moss shows the relevance of historical accounts focused on accountability analysis to inform our understanding of energy transitions today by deconstructing assumptions along spatial and temporal axes. His overarching point is that histories of energy provision and use can be instructive sources of inspiration. The issue of accountability is not the preserve of present-day energy governance. It has been invoked in myriad ways in the past to justify energy solutions in certain places at certain times. History helps us understand accountability, 
therefore, as a situated political construct. This sensitises scholars not only to the variety of justifications that have been mobilised in the name of particular purposes and beneficiaries in the past but also to the ephemeral nature of accountability criteria. What today may seem self-explanatory, may tomorrow be questioned.

History can point us to times and places when crises of accountability did challenge prevalent logics, policies or practices of energy provision. Such critical junctures can reveal past attempts to delegitimate a hegemonic sociotechnical configuration and assess their achievements with the benefit of hindsight. At the same time, history can generate an appreciation of the obduracy of argumentative tropes enrolled to legitimate the predominant system. As the Berlin case illustrated, institutional norms can prove just as path dependent as the material structures they regulate. The fixation on energy security - and the capacity reserves this engendered-in West Berlin during the Cold War era created a legacy of insularity with which the city is still struggling to cope even 30 years after reunification.

Finally, history can direct attention to the roots of sustainability thinking in a particular space-time context. Sustainability as we know it was not a term in use before the 1970s, but its origins can be instructive, such as past efforts to save energy, use renewables or challenge supply-driven logics of supply. The social movements pioneering novel modes of accountable energy governance in Berlin today cannot be comprehended fully, Moss argues, without reference to their forebearers and the historically constructed sociotechnical regimes they challenged in bygone decades.

Christian Lund employs a conflict-centred approach anchored in a reading of classic texts within development studies, political science and political ecology to show how empirical examination of accountability is linked with the constitution of authority and subjecthood. Lund's (2016) overall argument is that to treat the 'state' (or any other institution) as a finished product gets in the way of understanding it. It is always in the making. Political authority is (re)produced through its successful exercise; especially when exercised over important issues in relation to the social actors concerned.

Arguably, when institutions recognise claims to rights, they themselves become recognised by the claimants of these rights. That is to say, rights and authority are mutually and simultaneously established. Claims therefore invoke public authority and governing capacity in different institutions, be they statutory or not. And, conversely, those who can claim to authorise people's claims to rights acquire and exercise political authority. 
This dynamic is garnered with attempts at legitimating the claims to rights and authority. However, just as the institutions are never truly settled but are, in fact, processes, the repertoires of legitimation are also contingent. To understand these dynamics of institutional formation requires grounded, empirical research allowing us to go beyond state theories modelled after ahistorical ideal types.

Lund's argument thus points to directions where fieldwork-based analyses of accountability can attend to indirect and under-attended aspects of energy transitions.

Håvard Haarstad brings a human geography and urban planning lens to bear on accountability along with a science and technology studies concern with metrics, revealing the relational modulation of energy transitions across multiple scales. His chapter deals with the question of whether climate targets matter for actual policy implementation. He observes that climate-related targets are all around-countries have them, regions have them, cities have them. Does this have any effects on how practical politics proceed, on what happens in practice? Much of the social sciences would take a sceptical view. Swyngedouw's (2010) popular rendering of the 'post-political condition', for example, describes climate targets as part of a techno-managerial apparatus that shifts rhetoric towards climate change but at the same time makes sure that nothing actually happens. While recognising the merits of a sceptical view, Haarstad aims to look at the other side of this coin. Is it possible that targets, even seemingly overly ambitious ones, may have real and substantive effects contributing to a sustainable transition?

He starts from the basic idea that there is power in numbers. As many social scientists have pointed out, quantification makes nature knowable and controllable (Miller 2005). This could mean that reducing a sustainable transition-a messy, complicated and multifaceted process-to a quantifiable target can have powerful effects. In fact, While et al. (2010) argue that, by lending itself to quantification, climate change becomes a potentially powerful target of political action and regulation. Haarstad points to one instance of how a quantified goal (zero) becomes enrolled and legitimated in political practice and, arguably, effects substantive change. Since 2006, the goal of having 'zero growth' in private car traffic has worked its way into Norwegian policy-making across a range of areas, particularly transport and urban development. It affects flows of funding from the national government to the major cities. It has become a major condition for urban policy-making. 
This illustrates how a quantified target has the potential to work its way into the 'techno-managerial apparatus' (Swyngedouw 2010) and inflect material change. This particular case entailed a combination of involved soft mechanisms, as the target gradually inserted itself in the discourse on urban policy and moved its goal posts, and hard mechanisms, namely national-to-urban funding flows. The takeaway message is that climaterelated targets can play an important role in legitimating practices that advance sustainable energy transitions.

Benjamin Sovacool demonstrates how a political economic, multi-sited comparative deconstruction of sectoral change from a public policy and social justice perspective can surface uneasy questions about accountability even in progressive energy transitions. Such an analysis offers a compelling antidote to the optimism inherent in much current discussion and debate about the desirability of electric mobility as a pathway for environmental sustainability. In this context, due to the transportation sector's dependence on fossil fuel energy sources and the monumental negative consequences for climate change, air pollution and other social impacts, countless researchers, policymakers and other stakeholders view a widespread transition to electric mobility as both feasible and socially desirable (Mitchell et al. 2010; Tran et al. 2012). The International Energy Agency (2017) projects under the 'Sustainable Development Scenario' that 875 million electric vehicles (EVs) will need to be adopted by 2040. Mitchell et al. (2010) call EVs nothing short of 'transformative' and 'revolutionary' for their potential effects on mobility patterns. Turton and Moura (2008, p. 1091) add that when EVs are placed in a vehicle-to-grid configuration, their transformative potential multiplies, representing 'a paradigm shift in how the energy and mobility markets are related'.

However, the Nordic transition to electric mobility when viewed from a framing of sector-wide multi-scalar linkages, questions this so-called revolution. It underscores how wedding accountability to analyses of vulnerability and justice in energy transitions can fruitfully change the frame and criteria by which we examine mobility transitions. In addition, many of the injustices identified, or the issues of equity and vulnerability that arise, are not 'new' to electric mobility-they likely exist with other low-carbon technologies and also conventional cars and other forms of mobility. However, a lesson here is perhaps that changing the performance or engine of a vehicle, or introducing a new type of car such as battery electric vehicle, does not necessarily change the underlying political economy or power dynamics behind mobility or automobility. Systems of mobility 
themselves-involving multiple, competing and overlapping technologies, modes of mobility and transport infrastructures-can also be just or unjust, even if they utilise innovations such as electric vehicles. The justice potential of electric mobility is therefore situational, relational and contingent.

Steven Wolf develops an environmental sociology framework to address dynamics in biodiversity conservation. The case of the sage-grouse, a ground-nesting bird imperilled by energy development in Colorado, USA, offers a window onto broader challenges of energy transitions and socioecological regulation. The chapter pursues a general, abstract analysis of accountability within environmental governance. Accountability mechanisms are identified as 'tests' of conformity with institutionalised norms. These tests mediate access to legitimacy and other resources that structure competition and organisational ecology dynamics (i.e., shifts in the population of actors and behaviours) (Kraft and Wolf 2018). The co-evolutionary model of socioecological regulation that is presented seeks to offer an integrated, dynamic treatment of accountability (e.g., social controls developed to regulate land use changes that reduce sage-grouse habitat), standards of legitimacy (e.g., prevailing norms regarding the appropriateness of accountability mechanisms), sociotechnical practices (e.g., oil and gas drilling activities) and environmental quality (e.g., health of sagegrouse populations). This theoretical treatment highlights opportunities for research on accountability to inform general analyses of governance and regulation.

The empirical analysis highlights how efforts to advance habitat offsetting (i.e., market-based approaches to conserving land in order to compensate for degradation of sage-grouse habitat) have served to maintain the legitimacy of existing models of oil and gas development. More specifically, Wolf's analysis highlights how multi-stakeholder dialogue around construction of habitat offsetting mechanisms and mobilisation of scientific expertise and quantification routines are implicated in performing conservation without producing measurable protections for sage-grouse. To date, after seven years of engagement, no habitat has been conserved in Colorado through the habitat exchange. Yet the public construction of elaborate new accountability routines and promises of future capacity to achieve 'no-net loss' of habitat seems to function adequately to legitimate existing socioecological relations. In this sense, accountability processes are a central mechanism through which we sustain the unsustainable (Blühdorn 2007). 
To conclude, we come full circle to the urgency of the climate change challenge, the need for sustainable energy transitions, and the conundrum that such sociotechnical transitions are feasible and desperately needed despite which they are held back in a wide variety of ways. The response unpacked by means of an accountability-centred analytical approach is that a dynamic configuration of legitimation practices that constrain and enable sustainable energy transitions manifest this conundrum. Identifying and evidencing these practices as applied researchers and analytically oriented practitioners, we can unravel the present conundrum and advance accountable governance for sustainable energy transitions. We trust that the pointers and reflections offered in this book will motivate and equip colleagues to support this endeavour.

\section{REFERENCES}

Blühdorn, I. (2007). Sustaining the unsustainable: Symbolic politics and the politics of simulation. Environmental Politics, 16, 251-275.

International Energy Agency. (2017). World energy outlook 2017. Paris: OECD.

Kraft, B., \& Wolf, S. (2018). Through the lens of accountability: Analyzing legitimacy in environmental governance. Organization \& Environment, 31, 70-92. https://doi.org/10.1177/1086026616680682

Lund, C. (2016). Rule and rupture. State formation through the production of property and citizenship. Development and Change, 47(6), 1199-1228.

Miller, C. (2005). New civic epistemologies of quantification: Making sense of indicators of local and global sustainability. Science, Technology and Human Values, 30, 403-432.

Mitchell, W. J., Borroni-Bird, C. E., \& Burns, L. D. (2010). Reinventing the automobile personal urban mobility for the 21st century. Cambridge, MA: MIT Press.

Sareen, S. (2019a). Practices of legitimation and accountability crises in a range of energy transitions. In Enabling sustainable energy transitions: Practices of legitimation and accountable governance. London: Palgrave Macmillan.

Sareen, S. (2019b). A typology of practices of legitimation to categorise accountability relations. In Enabling sustainable energy transitions: Practices of legitimation and accountable governance. London: Palgrave Macmillan.

Swyngedouw, E. (2010). Apocalypse forever? Post-political populism and the spectre of climate change. Theory, Culture \& Society, 27, 213-232.

Tran, M., Banister, D., Bishop, J. D. K., \& McCulloch, M. D. (2012). Realizing the electric-vehicle revolution. Nature Climate Change, 2, 328-333. 
Turton, H., \& Moura, F. (2008). Vehicle-to-grid systems for sustainable development: An integrated energy analysis. Technological Forecasting and Social Change, 75, 1091-1108.

While, A., Jonas, A., \& Gibbs, D. (2010). From sustainable development to carbon control: Eco-state restructuring and the politics of urban and regional development. Transactions of the Institute of British Geographers, 35, 76-93.

Open Access This chapter is licensed under the terms of the Creative Commons Attribution 4.0 International License (http://creativecommons.org/licenses/ by $/ 4.0 /$ ), which permits use, sharing, adaptation, distribution and reproduction in any medium or format, as long as you give appropriate credit to the original author(s) and the source, provide a link to the Creative Commons licence and indicate if changes were made.

The images or other third party material in this chapter are included in the chapter's Creative Commons licence, unless indicated otherwise in a credit line to the material. If material is not included in the chapter's Creative Commons licence and your intended use is not permitted by statutory regulation or exceeds the permitted use, you will need to obtain permission directly from the copyright holder.

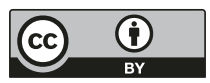




\section{Appendix A}

\section{A Workshop, Parallel Exhibitions and Associated EvENTS}

Several factors ensured a productive and convivial writing process, and made this book possible. The conditions of its production also served a further purpose through their own ontology, embodying its intent of being accessible to a wider audience. This appendix tells the story of much of what went into the making of this book and the collaborations that inform it.

Stemming from concerns of social and environmental equity and justice, my interest in accountability has been informed by instruction from and engagement with the co-authors. Christian Lund's work on how authority is produced in reflexive relation with claims over rights motivated a focus on relational practices. Steven Wolf's work, drawing together accountability, legitimation and empirical artefacts-captured in Kraft and Wolf (2018) — shaped thinking around practices of legitimation as an entry point to the empirical study of accountability. Håvard Haarstad's work on relational ontology and the networked governance of efforts to decarbonise informed the development of a relational approach. Benjamin Sovacool's work on energy justice was instructive in determining how to engage decarbonisation and social equity enhancement as twin aspects of accountability in governing energy transitions to sustainability. Timothy Moss' work, deepening historical understandings of energy transition 
drivers, nuanced views on the basis for and implications of contemporary energy sector accountability relations.

These scholars generously agreed to engage and contribute insights based on their empirical work to collectively consider an analytical approach centred on the study of practices of legitimation. Featuring their work from fields as varied as human and economic geography, development studies, energy studies, environmental sociology and history enables the book to speak to colleagues across wide-ranging disciplines and applied research traditions. This aims to catalyse a greater analytical focus on accountable energy transitions within environmental governance scholarship.

In addition, vibrant fields of social science research on the governance of energy transitions and cognate subjects furnished arguments to engage with and concepts to inspire and direct critical thinking. A workshop grant enabled the co-authors to come together in Bergen during 14-17 May 2019 , along with authors of 15 manuscripts prepared for a special issue of the Global Transitions journal on a closely related theme, for two days of discussions amongst over 20 scholars. For this opportunity, I am grateful to the Strategic Programme for International Research Collaboration, and to the Faculty of Social Sciences at the University of Bergen. In parallel with this workshop, I co-organised two public exhibitions. The first was built around the concept of an 'Idea box for energy transitions', and the second was a collaboration within a show titled 'Potential exceeds the demand' by textile artist Margrethe Brekke.

The idea box for energy transitions was a physical invitation to the public to contribute their solutions for energy transitions by putting sheets with their writing into a slot in a box painted in the yellow colour of the Sustainable Development Goal (SDG) 7. This SDG aims to achieve clean energy for all. I designed the idea box largely from upcycled materials, and with the assistance of several colleagues, curated workshops to collect solutions. The idea box was launched at the opening weekend of the European Green Capital 2019 in Oslo, from where people posted ideas to Bergen. It was then installed at the Bergen Public Library from January to March 2019, and carried around to workshops during this period. These included a workshop on the accountable governance of sustainable energy transitions during the National SDG Conference 2019, workshops with teachers and citizens interested in energy, and an event integrated into the Klimathon (an annual national event on climate adaptation). A group of colleagues at the Centre for Climate and Energy Transformation built an 
exhibition around the ideas that came in, which ran during 10-20 May 2019 at the Bergen Public Library. This included a selection of books related to energy transitions as well as prints of 17 motifs from a 6.25 square metre textile art from the other exhibition, alongside the idea box itself.

The collaboration with Margrethe Brekke's exhibition emerged organically during late 2018. Hosted at the Hordaland Kunstsenter art gallery during May-July 2019, this exhibition provided visual portrayals of existing possibilities for energy transitions. We discussed ways of depicting a future energy system powered largely by renewable energy, with her visualisations and my technical inputs. This resulted in her textile piece titled 'Rhythmic energy mixes: Days and years with Dr. Siddharth Sareen', which emphasised flexible daily and annual cycles of such energy systems. Details of the motifs she developed for this large piece were part of the parallel idea box exhibition. The Hordaland Kunstsenter exhibition also featured a poem I wrote and performed during an event called 'Fest for Fesken' (party for the fish) organised by the people's campaign for a fossilfree Arctic (Folkeaksjonen oljefritt Lofoten, Vesterålen og Senja) at Bergen's Café Opera on 14 November 2018, reflecting on my time spent engaging with climate activism in the sister city of Seattle during September-October 2018. This poem, 'The case for hope amidst climate change catastrophe', was recorded and displayed on headphones with accompanying visuals that featured Brekke's textile art, and the book concludes with it.

During the mid-May workshop, I anchored a discussion between Margrethe Brekke and Benjamin Sovacool on the 'Imaginaries of energy transition: Public, artistic and academic' at the art gallery. Judith Dalsgård developed this into a podcast as part of a series at the Centre for Climate and Energy Transformation. Workshop participants and interested local residents toured Brekke's exhibition and were also given a tour of the idea box exhibition. These activities constituted a form of engagement with various publics beyond academia, including Bergen's cultural and artistic community. They also enabled two-way engagement rather than outreach, providing a window of insight into what people think about energy transitions and inviting them into a sustained exchange with energy scholars. The exhibitions built a basis for collaboration with public institutions such as Bergen Public Library and Hordaland Kunstsenter. Opening and closing sessions as well as six keynote talks (five of them based on the case chapters and a sixth by Sunila Kale) during the mid-May workshop were 
livestreamed and made permanently available on the Youtube channel of Bergen Public Library. Children from the International School of Bergen, directed by Annie Sareen, contributed short thematic theatrical performances during the workshop.

As with many things, it is possible to say that 'it takes a village' to govern energy transitions to be accountable to public interests like decarbonising while enhancing social equity. The ontology of producing the content of this book, by way of the workshop and these parallel events, took many parts of the city of Bergen. Along with any influence it might have on wider audiences, this local effect of connecting people and institutions constitutes a key outcome of the book project. Such efforts are vital for building a platform to nurture greater public awareness regarding the accountable governance of energy transitions. Documenting them as part of this book closes the circle and hopes to encourage others to undertake similar efforts customised to their local contexts. Appendix B complements this textual narrative with a photographic essay that captures some key details of the events that took place in Bergen during May 2019.

\section{REFERENCE}

Kraft, B., \& Wolf, S. (2018). Through the lens of accountability: Analyzing legitimacy in environmental governance. Organization \& Environment, $31(1), 70-92$. 


\section{Appendix B}

\section{Photos from the Events in Bergen, May 2019}

This appendix, a photo essay, documents visual details from two exhibitions that ran in parallel with the mid-May workshop in Bergen, and from the workshop itself. ${ }^{1}$ It is divided into four sections: photos from the 'Idea box for energy transitions' exhibition at Bergen Public Library, photos from the 'Potential exceeds the demand' exhibition at the Hordaland Kunstsenter art gallery, photos from the workshop titled 'Accountability analysis: Enabling sustainability under energy sector transitions' and a poem that was part of the art gallery exhibition. All photos were taken during 9-17 May 2019 in Bergen.

\section{The Idea Box for Energy Transitions - An Exhibition at Bergen Public}

\section{Library}

Several colleagues associated with the Centre for Climate and Energy Transformation at the University of Bergen helped me curate the 'Idea box for energy transitions' exhibition-Judith Dalsgård, Thea Gregersen, Tshin Ilya Chardayre, Gregory Ferguson-Cradler and Amber Nordholmalong with collaborating artist Margrethe Brekke and the director of Hordaland Kunstsenter, Mathijs van Geest. Several of us are pictured here,

\footnotetext{
${ }^{1}$ Except Figs. B1.2, B1.3 and B1.7 where the Hordaland Kunstsenter art gallery is duly credited, all photos used were taken or arranged by the author.
}

(C) The Author(s) 2020

S. Sareen (ed.), Enabling Sustainable Energy Transitions, https://doi.org/10.1007/978-3-030-26891-6 


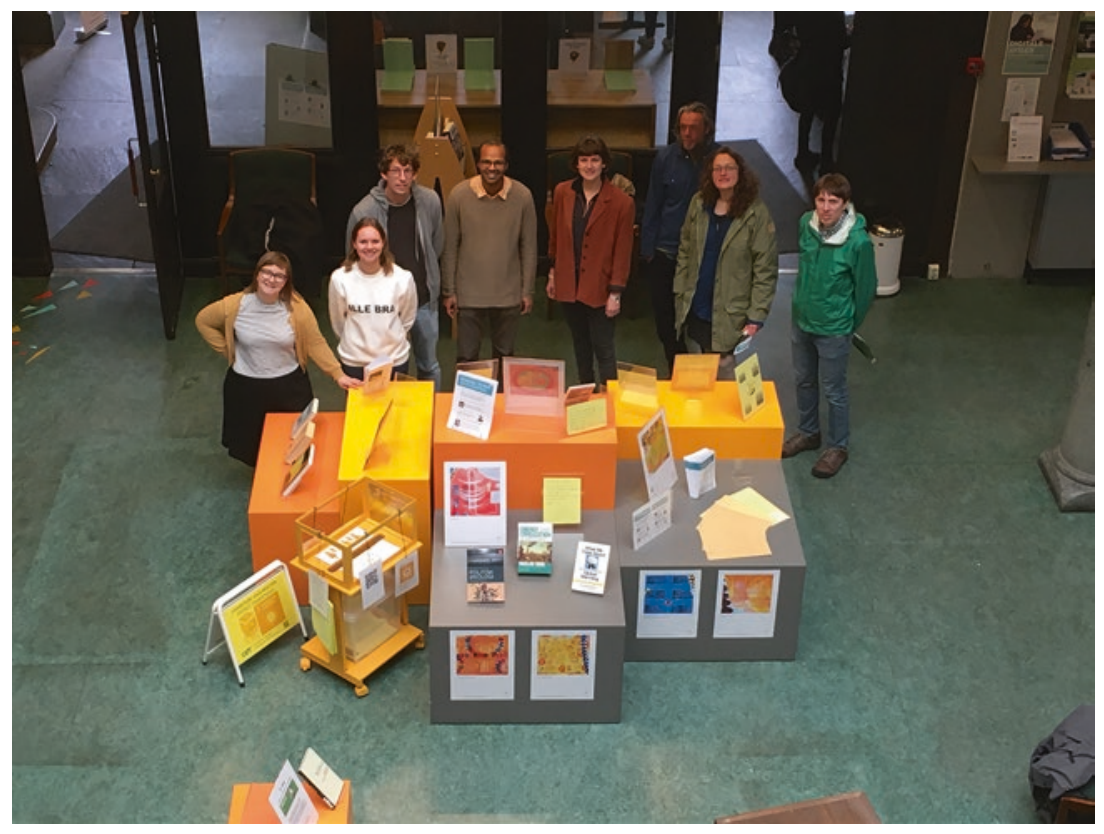

Fig. B1.1 Setting up the exhibition at Bergen Public Library

right after having finished installing the exhibition a day prior to its opening on 10 May 2019 at Bergen Public Library.

The exhibition featured a selection of solutions for energy transitions submitted by the public through various workshops, as well as an assortment of thematically pertinent books, and motifs from a large textile piece at the parallel exhibition at Hordaland Kunstsenter. It was placed in a central room at the Bergen Public Library to share the crowd-sourced social imaginary with people in Bergen. 


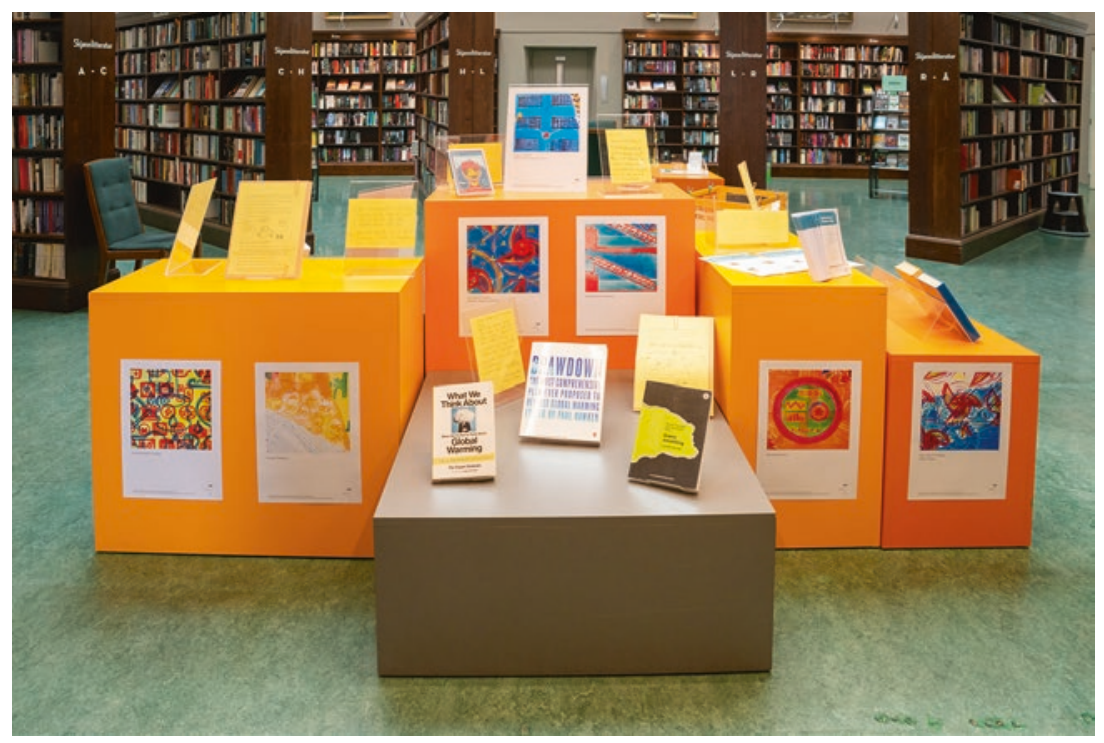

Fig. B1.2 The 'Idea box for energy transitions' exhibition. (Photo credit: Hordaland Kunstsenter)

The exhibition was installed in a manner that invited engagement, and designed to be approachable from any direction. People could leaf through folders with ideas, take a brochure with background information about the initiative with them, and pick up a flyer of the workshop held in the same building during the exhibition. The idea box itself, which collected ideas during January-March 2019, is also visible as part of the exhibition. The exhibition was listed as an Energy Days event and associated with the European Union Sustainable Energy Week. 


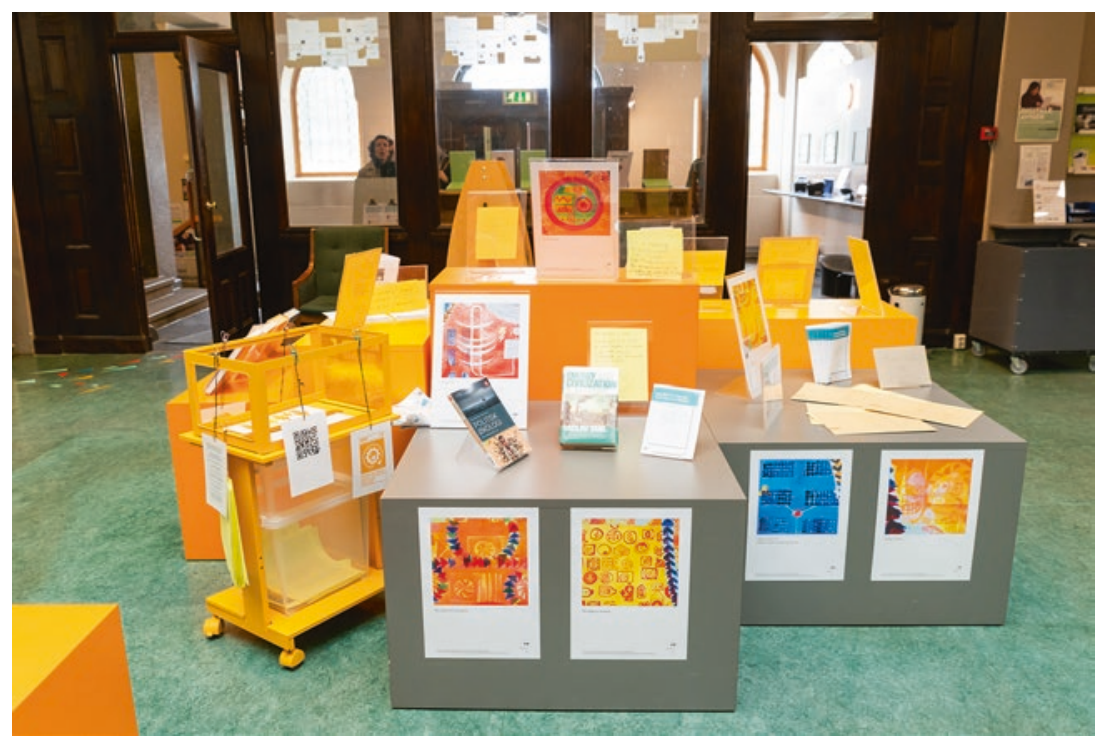

Fig. B1.3 The idea box as part of the exhibition at Bergen Public Library. (Photo credit: Hordaland Kunstsenter)

During the workshop, 20 researchers from abroad spent three days discussing analytical approaches centred around accountability for the governance of energy transitions towards sustainability. On the afternoon of 15 May, they stepped out of the auditorium at Bergen Public Library to take a look at the exhibition in the main space of this century old institution. 


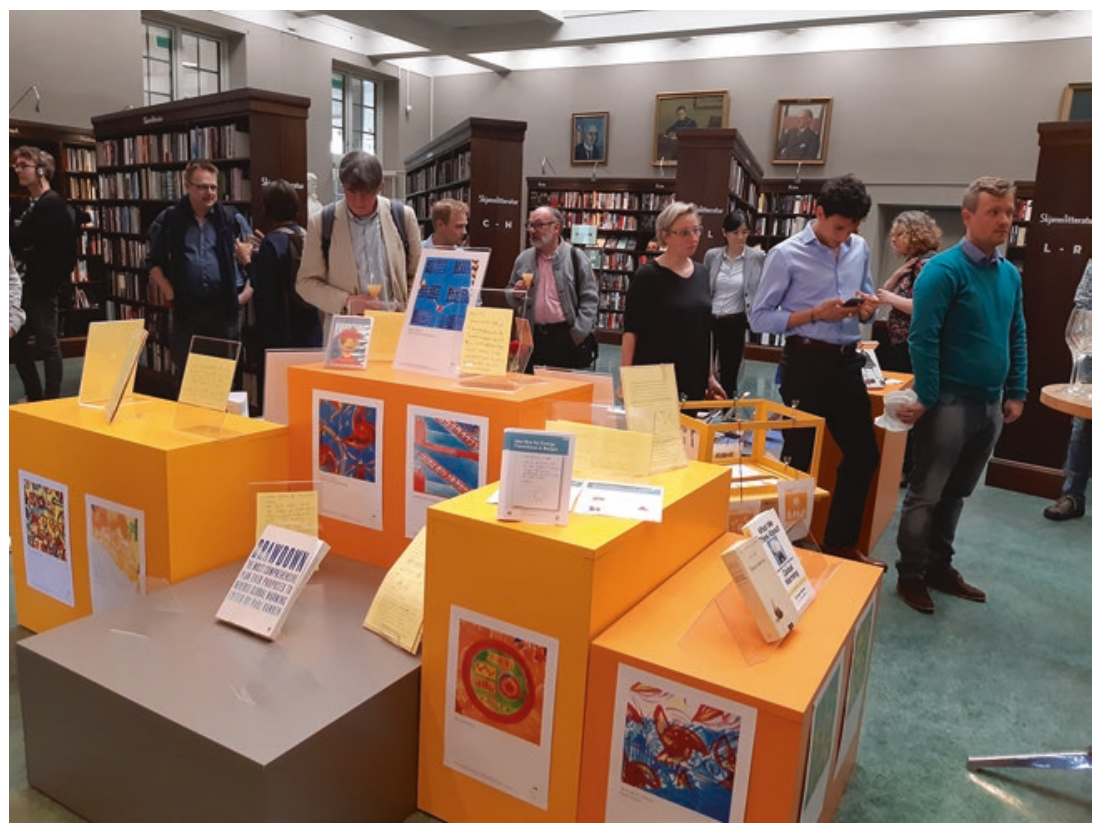

Fig. B1.4 Workshop participants browse the idea box for energy transitions exhibition

Those associated with the exhibition, including collaborating artist Margrethe Brekke, shared reflections on the process with workshop participants. Here, the art gallery director is explicating connections between the two exhibitions. 


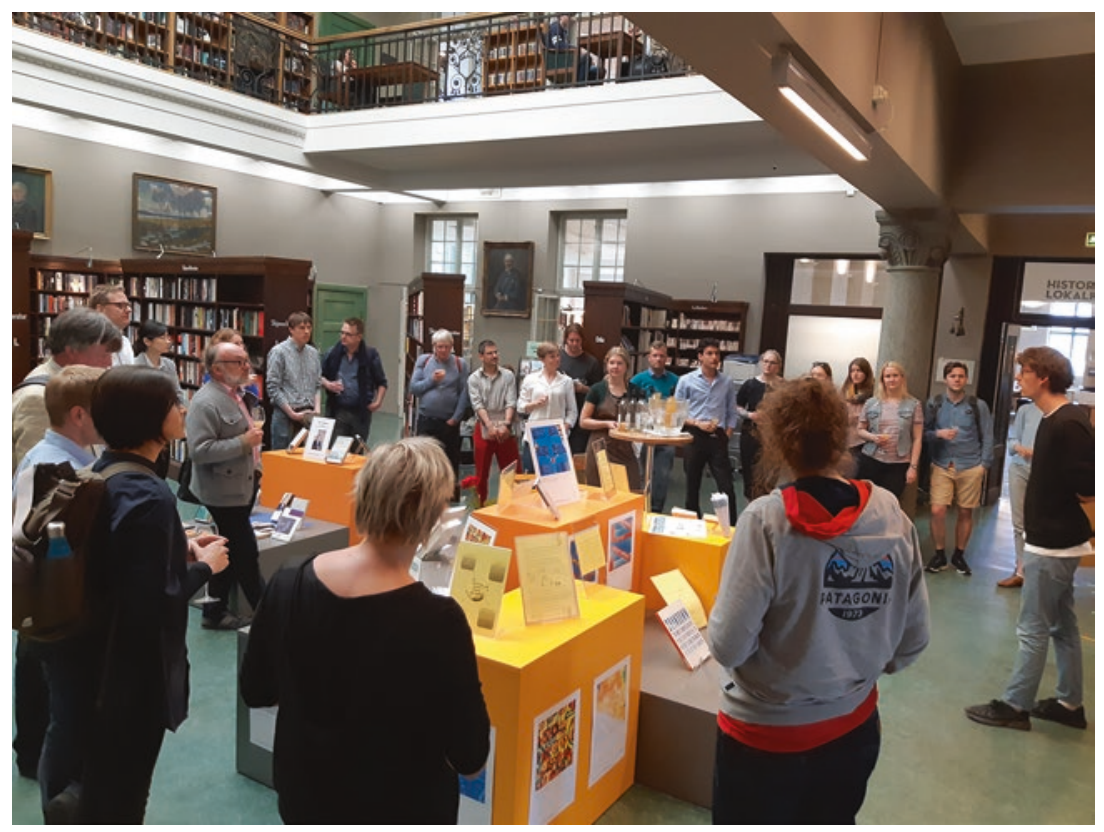

Fig. B1.5 Bridging the exhibitions at Bergen Public Library and Hordaland Kunstsenter

\section{Potential Exceeds the Demand-An Exhibition at Hordaland Kunstsenter Art Gallery}

The title of Margrethe Brekke's art exhibition emphasised the fact that we already have technological potential for low-carbon transitions far in excess of what is currently taking place. Our collaboration on one of her textile pieces revolved around visualising a future renewable energy system. The circular pattern with motifs representing many energy generating technologies highlights possibilities for flexibility, both daily and annually, in future energy systems with high levels of penetration of renewable sources of energy. It depicts the potential of technologies like agri-photovoltaics, concentrating solar power and reverse hydro pumping for a sustainable energy transition. 


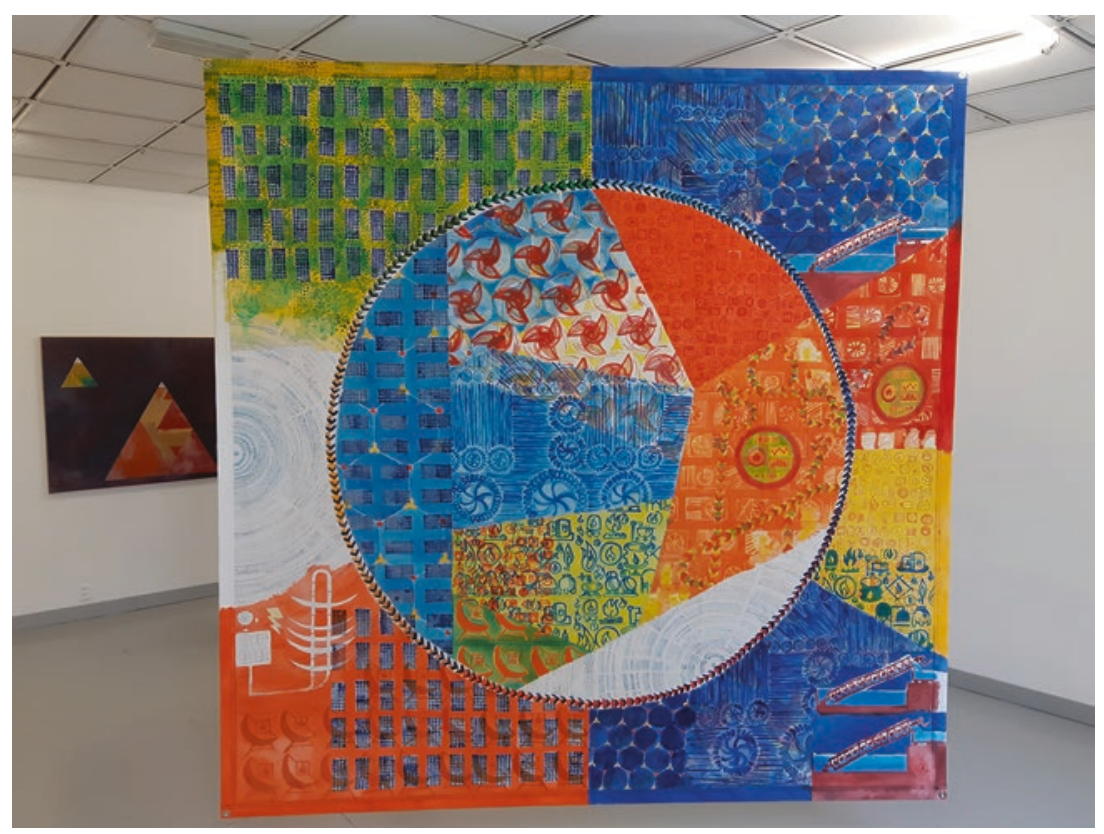

Fig. B1.6 'Rhythmic energy mixes: Days and years with Dr. Siddharth Sareen' by Margrethe Brekke

Margrethe Brekke's exhibition at Hordaland Kunstsenter featured three textile pieces of 6.25 square metres each, accompanied by some smaller works and two audio recordings with videos. The three large pieces dominated the art gallery space and conversed with each other. Each spoke to a wider audience based on scientific understandings of potential energy transitions, with basic shapes, colours and patterns representing specific volumes, proportions and time. 


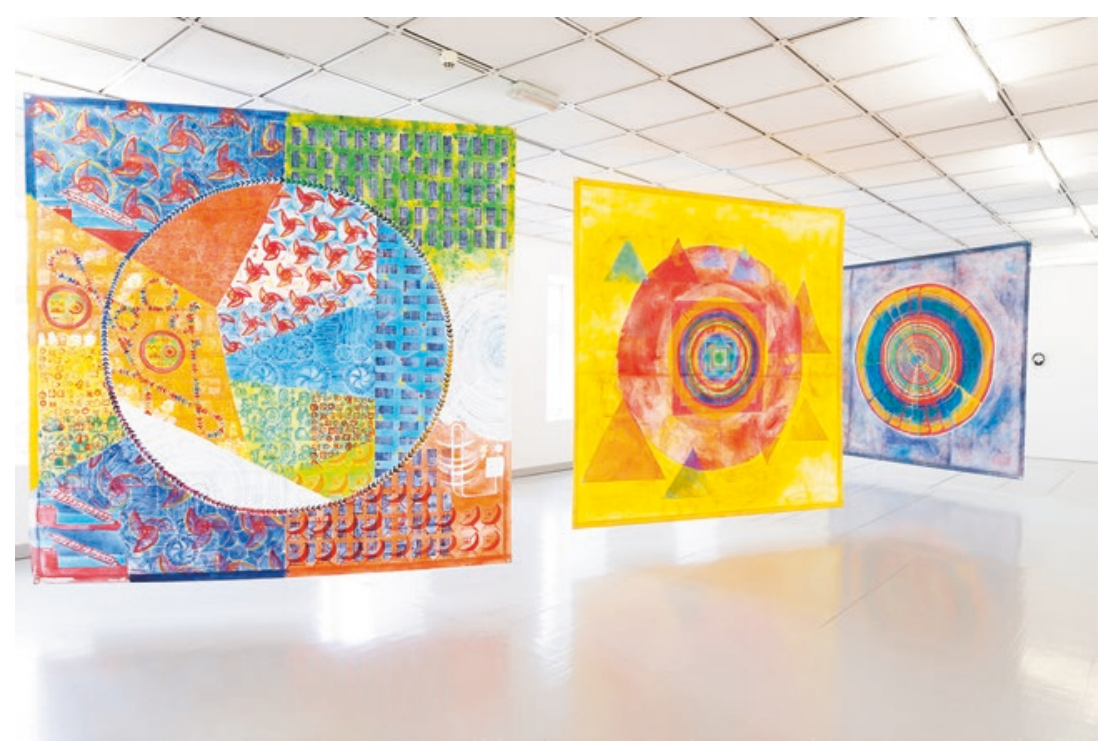

Fig. B1.7 Margrethe Brekke's 'Potential exceeds the demand' exhibition at Hordaland Kunstsenter

Margrethe Brekke gave a guided tour of her art exhibition to workshop participants and interested people in Bergen to kick off a collaborative art and academia evening event on 14 May 2019. This brought together those familiar with the city's cultural scene and several international visitors with insights from research on environmental governance and energy transitions. 


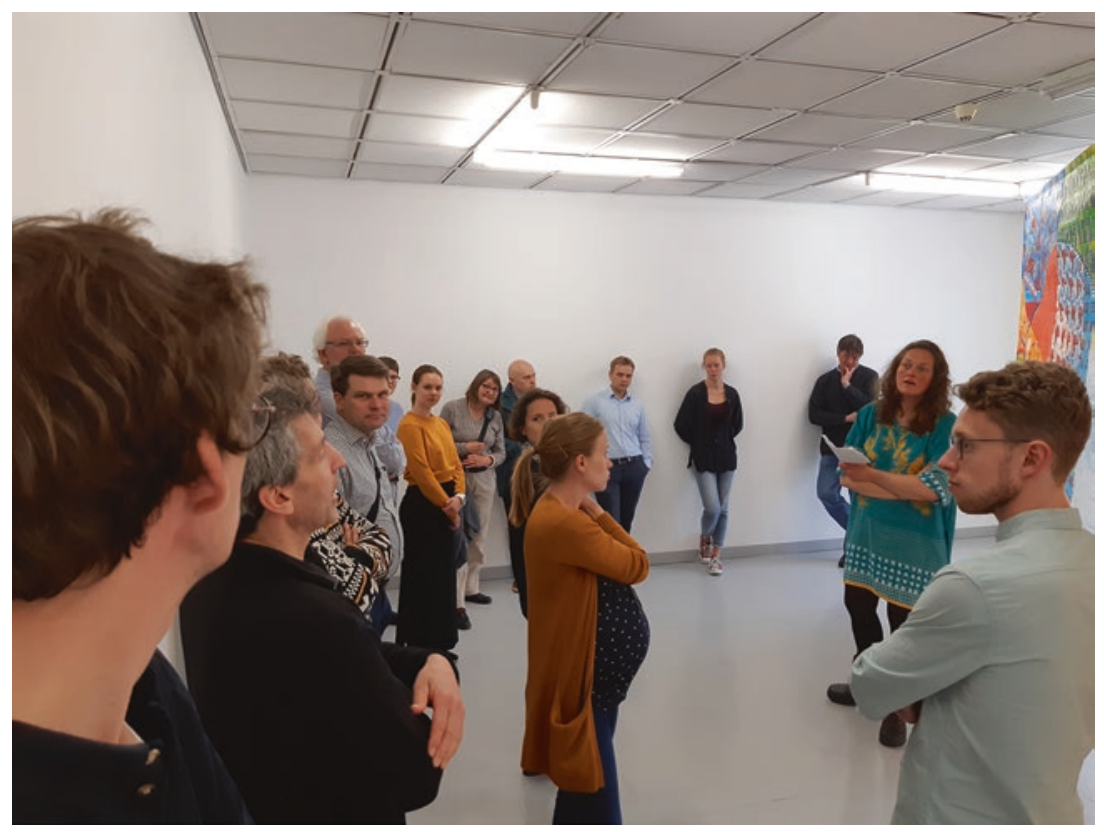

Fig. B1.8 Margrethe Brekke reflects on her art exhibition while giving a guided tour

Margrethe Brekke after giving a guided tour of her exhibition, with Annie Sareen, who directed a thematic performance by the children of the International School of Bergen the next day. In the background is Kristin Frøya, energy director at the University of Bergen, who also collaborated with Brekke for the exhibition with an audio recording that connected energy transitions with lived experience in Norway, and Timothy Moss, a keynote speaker at the workshop the rest of the week. The headphones on the wall featured an audio recording of my poem 'The case for hope amidst climate change catastrophe', whose text is included at the end of this appendix. 


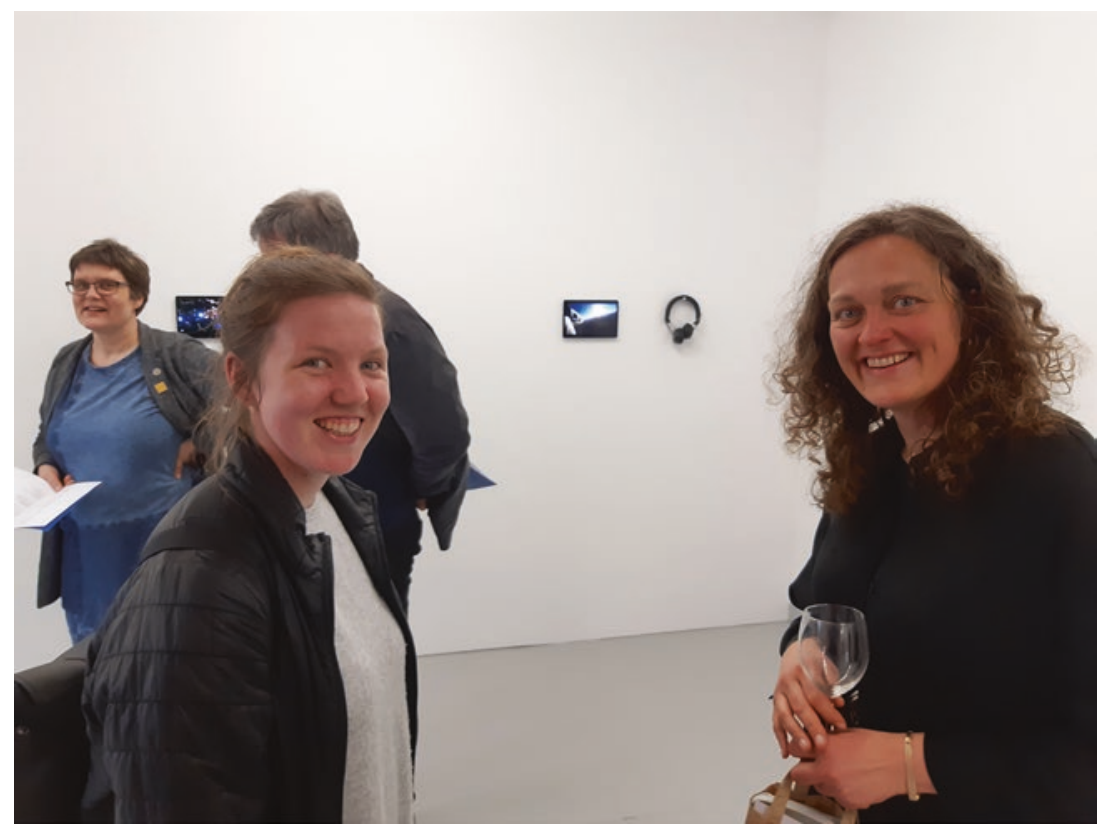

Fig. B1.9 The forces behind the artistic events

A large, engaged audience filled Hordaland Kunstsenter for the collaborative evening event. Here, they listen attentively to Magrethe Brekke's reflections on the role of the arts in enabling energy transitions, and experiences during her own journey from engaging utopian ideals to channelling scientific knowledge in her textile art. Benjamin Sovacool, a keynote speaker during the workshop and photographed here, followed Brekke's presentation by drawing from his research on energy justice and humanising energy transitions along lines of gender, labour and geographical topographies of power. Their talks and a discussion I moderated between them is available as an hour-long podcast, the sixth episode in the CET Climate Talks series. ${ }^{2}$

${ }^{2}$ Available online at https://www.uib.no/en/cet/124342/podcast-cet-climate-talks. 


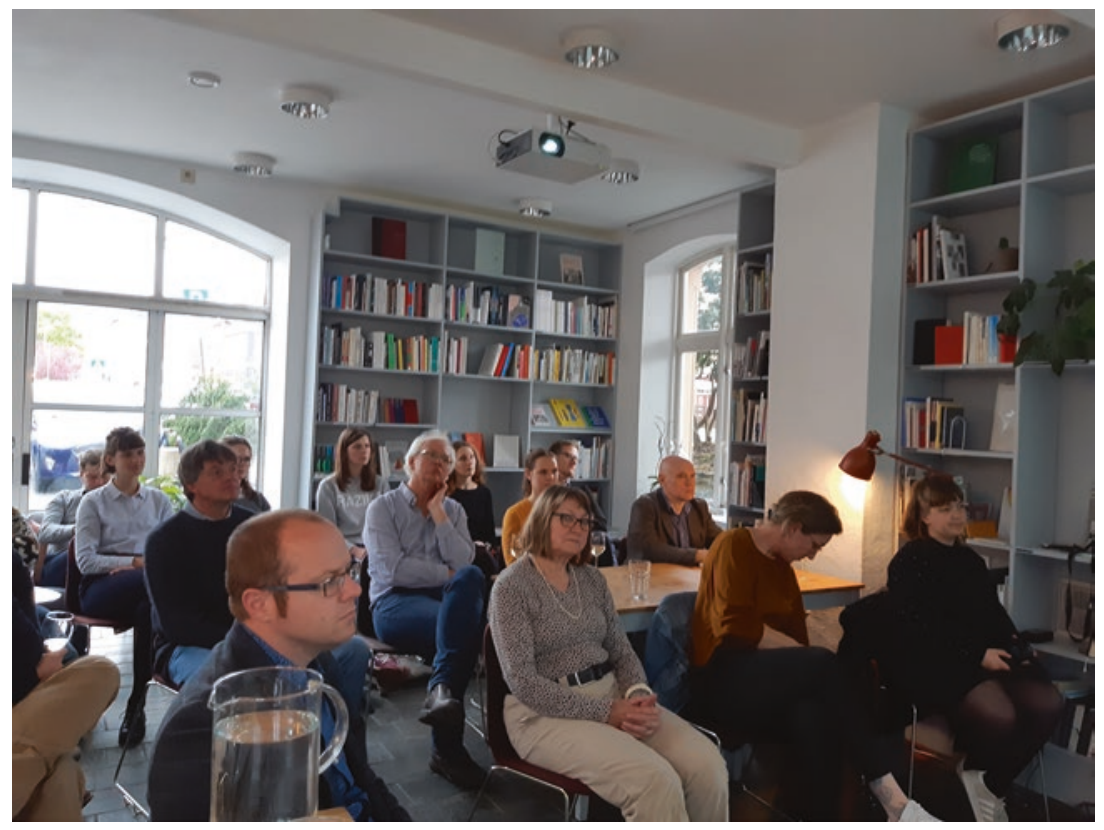

Fig. B1.10 'Imaginaries of energy transition: Public, artistic and academic' with Margrethe Brekke and Benjamin Sovacool

The discussion between Brekke and Sovacool was followed by a social evening and continued discussions on the theme amongst the audience, which included residents of Bergen and workshop participants who had just arrived in the city. 


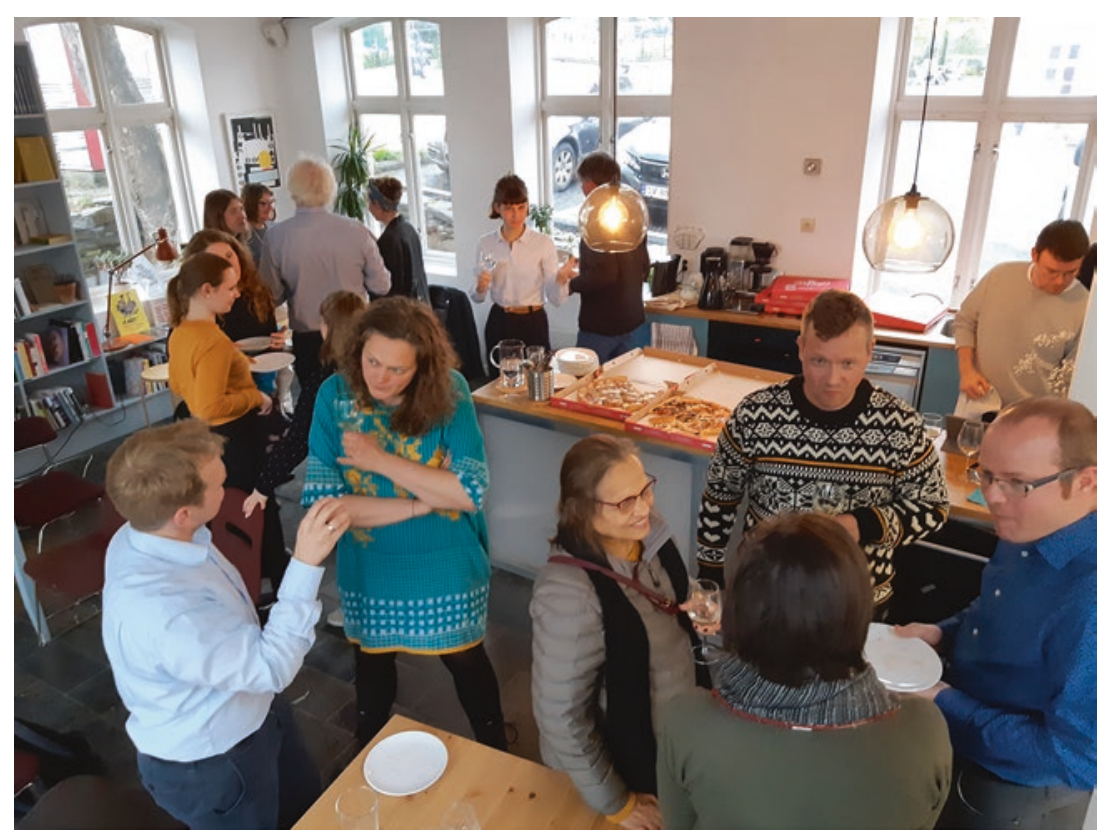

Fig. B1.11 Exchanges between the arts, academia and the public

Workshop on 'Accountability Analysis: Enabling Sustainability Under Energy Sector Transitions'

During the opening session of the workshop on accountability analysis and sustainable energy transitions in the main auditorium of Bergen Public Library, children from the International School of Bergen did theatrical performances on related themes, including climate change, deforestation and biodiversity, which they spent months preparing for as part of their classes on performing arts. 


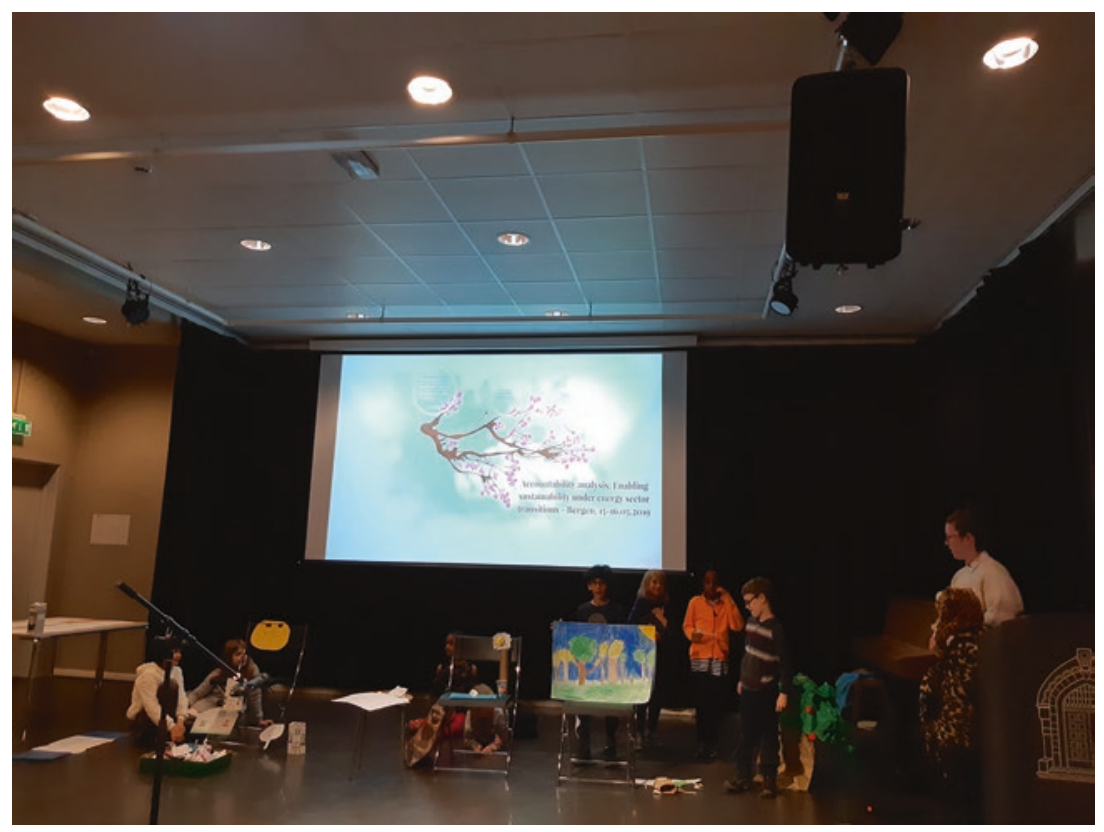

Fig. B1.12 Theatrical performances by International School of Bergen students directed by Annie Sareen

The workshop participants and other interested people in Bergen joined two intensive days packed with six keynote talks, 15 paper discussions and opening and closing sessions about practices of legitimation and accountability analysis for energy transitions governance towards sustainability. These discussions, which included all the co-authors of this book, were invaluable towards finalising this manuscript, as well as airing and providing feedback on articles that were subsequently submitted to a special issue of the Global Transitions journal on the same theme. 


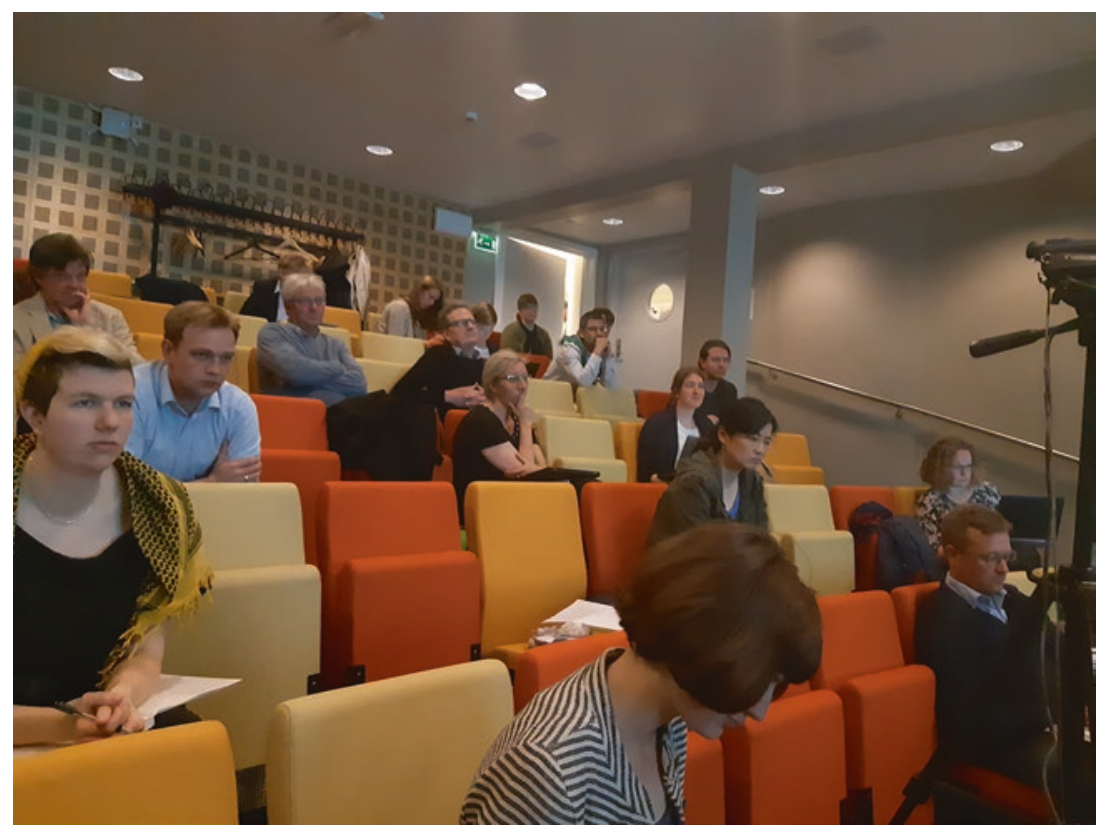

Fig. B1.13 The accountability analysis workshop at Bergen Public Library

The five case chapter authors of this book gave keynote talks during the workshop, as did Sunila Kale of the University of Washington-Seattle. Here, Timothy Moss gives the first of these keynotes, historicising accountability through Berlin's energy transitions, based on his argument in Chap. 4 of this book. These talks as well as the opening and closing sessions of the workshop were live-streamed and are available on the Youtube channel of Bergen Public Library. ${ }^{3}$

${ }^{3}$ Available online at https://www.youtube.com/user/bergenpubliclibrary/videos (dated 15-16 May 2019). 


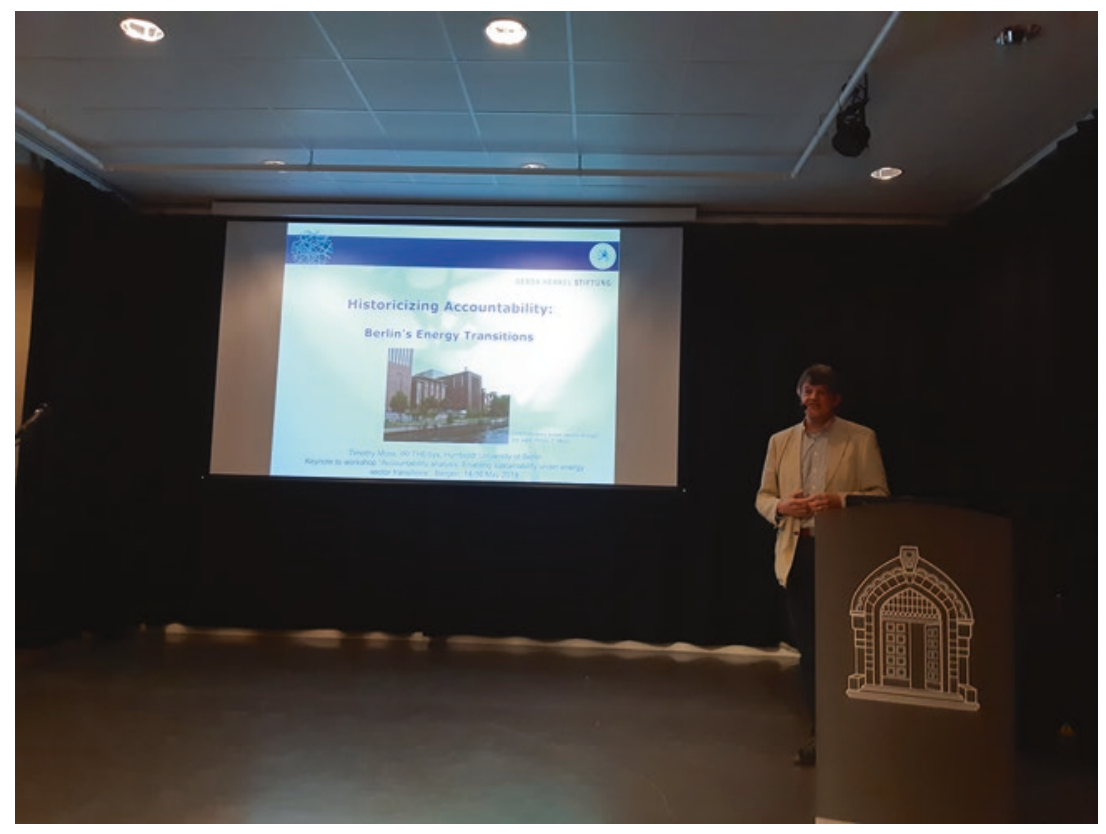

Fig. B1.14 Timothy Moss gives a keynote talk at the workshop on accountability analysis

The workshop keynote talks were followed by lively discussions where participants took the stage along with the speakers. The 15 paper presentations were presented by discussants based on pre-circulated manuscripts, with authors subsequently responding to these interpretations and leading into a discussion with the workshop participants. Here, Christian Lund poses a question to Håard Haarstad about his analysis of target-setting for climate mitigation, which comprises Chap. 6 of this book. 


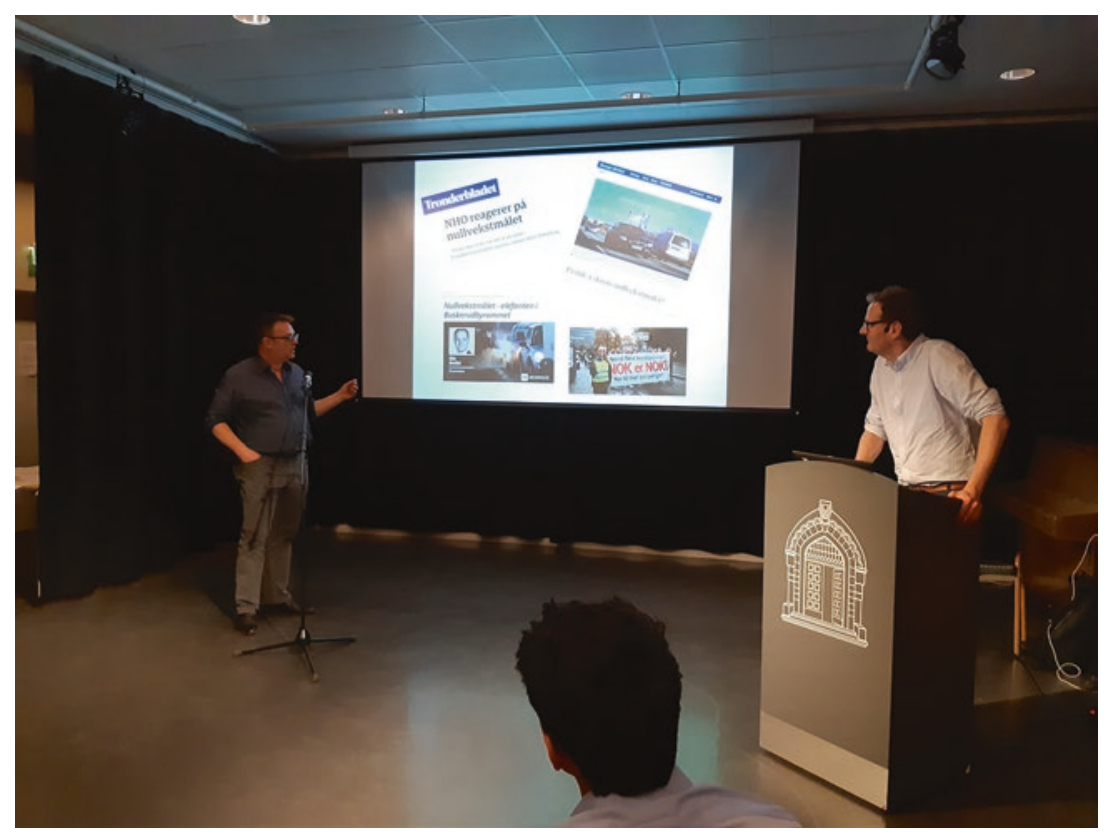

Fig. B1.15 Christian Lund and Håvard Haarstad during a workshop keynote session

The workshop also served as an occasion for researchers in many countries to become better acquainted and discuss their work on the governance of energy transitions and cognate themes in a relaxed social setting outside the academic sessions. At the end of the first of two days packed with sessions, participants gathered at the Bergen Public Library restaurant, Amalies Hage, for a long meal. 


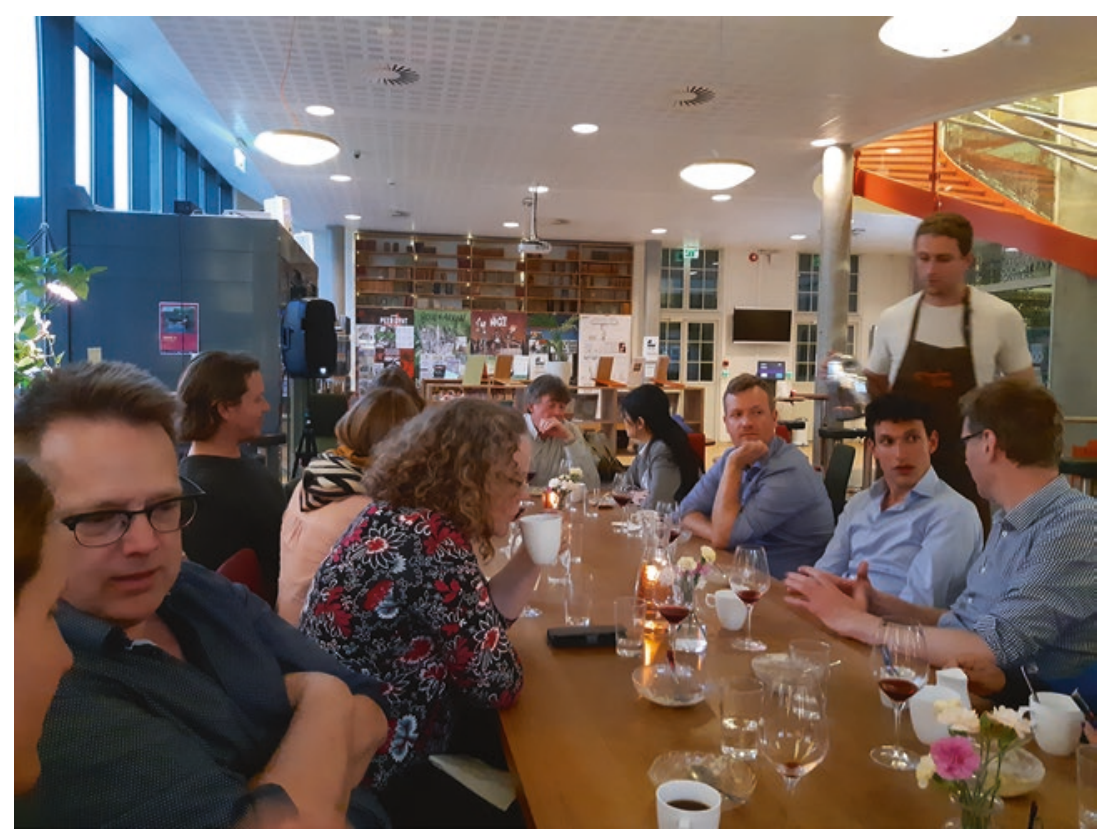

Fig. B1.16 Discussions among the workshop participants continued over dinner

At the end of two days of sessions, the workshop keynote speakers and some accompanying family members gathered over a closing dinner at the local restaurant Colonialen 44. Pictured from left to right are Steven Wolf, Annie Sareen, myself, Peter Andersen (head of the Department of Geography at University of Bergen), Christian Lund, Håvard Haarstad, Timothy Moss and his wife Ulrike, and Shobha succeeded by her daughter Sunila Kale. 


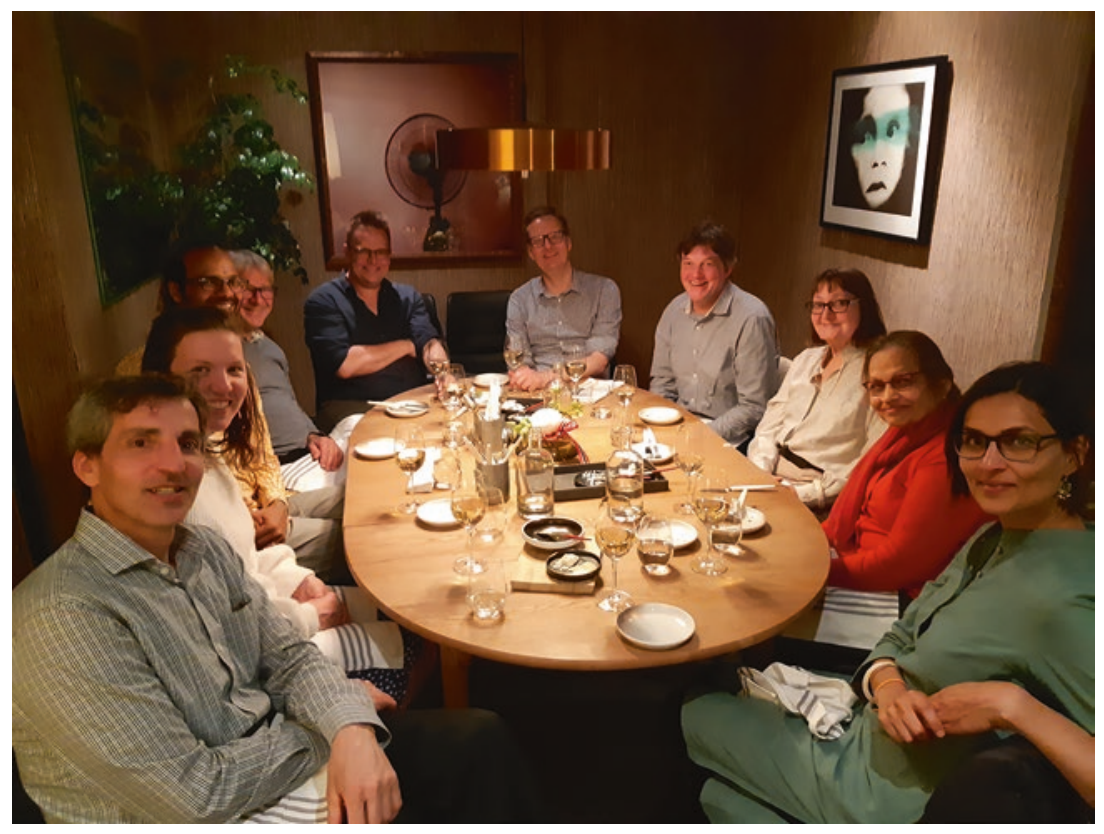

Fig. B1.17 Closing workshop dinner with keynote speakers

The workshop was planned to end with Norwegian Constitution Day, the national day of Norway, on Friday, 17 May 2019. This started with a traditional breakfast at the hotel where the keynotes stayed, by Bergen's central lake. Visible in the window is a passerby in her national dress, a bunad. Later in the day, workshop participants joined in the traditional parade through the city streets and spent a day enjoying Bergen at its best in glorious spring weather with happy people out and about. 


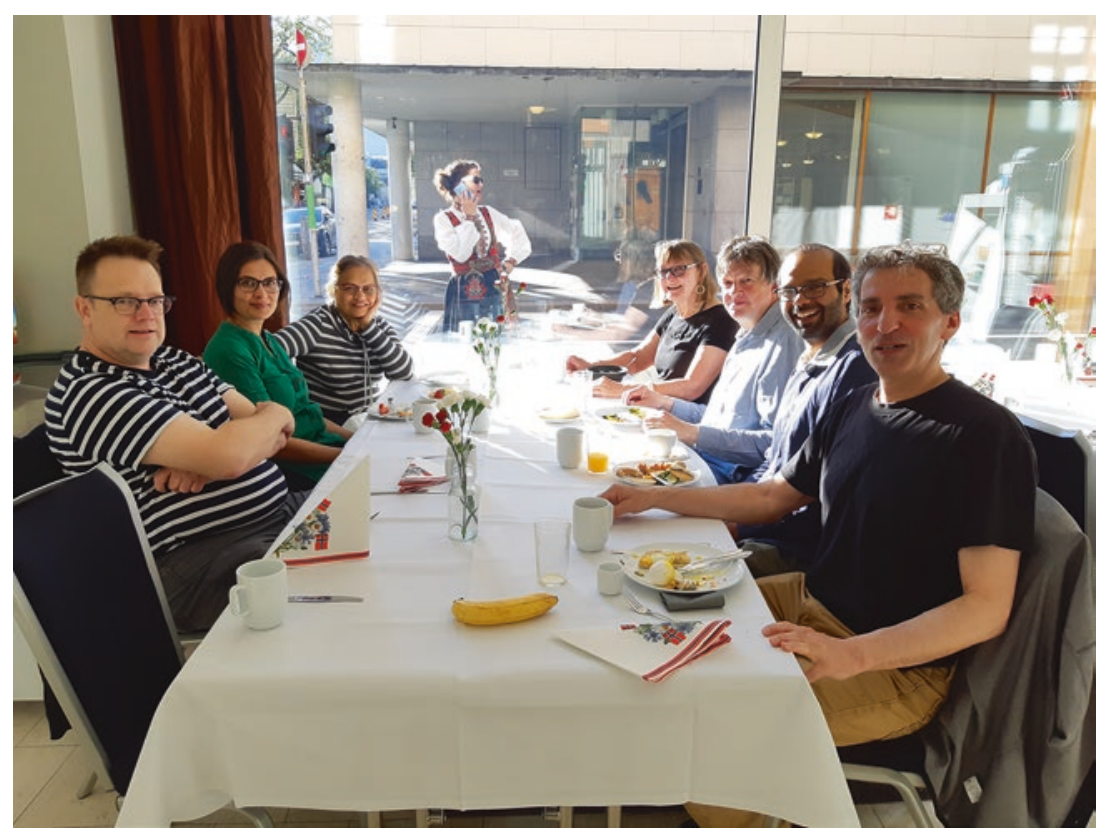

Fig. B1.18 Starting festivities on the national day of Norway

Some workshop participants joined the traditional closing procession, carrying torches from the thirteenth-century Bergenhus fortress past the famous Bryggen harbour and into the centre of Bergen where many residents had gathered for the annual public fireworks show to close the celebrations. In the middle is Lakin Anderson, a doctoral candidate at Uppsala University who participated in the workshop as part of his fieldwork to research the practices of climate and energy scientists at the Centre for Climate and Energy Transformation as a case study for his dissertation. 


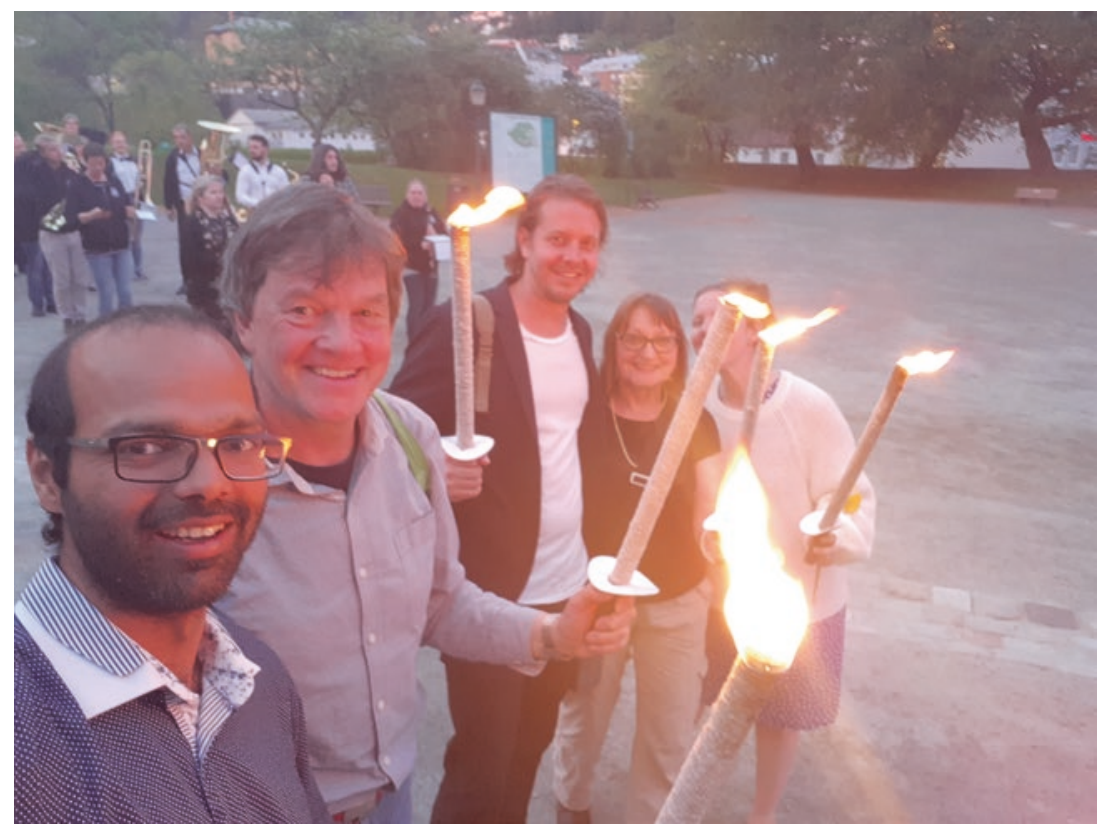

Fig. B1.19 A traditional torchlight procession through Bergen

The workshop ended with a bang with the annual fireworks show at the central lake in Bergen, called Lille Lungegårdsvannet (or Smålungeren in the Bergensk dialect). A viking boat mock-up is visible, and behind the fireworks one can discern the tallest of Bergen's seven mountains, Ulriken. With that, three intense and productive days of academic and wider collaboration drew to a close. 


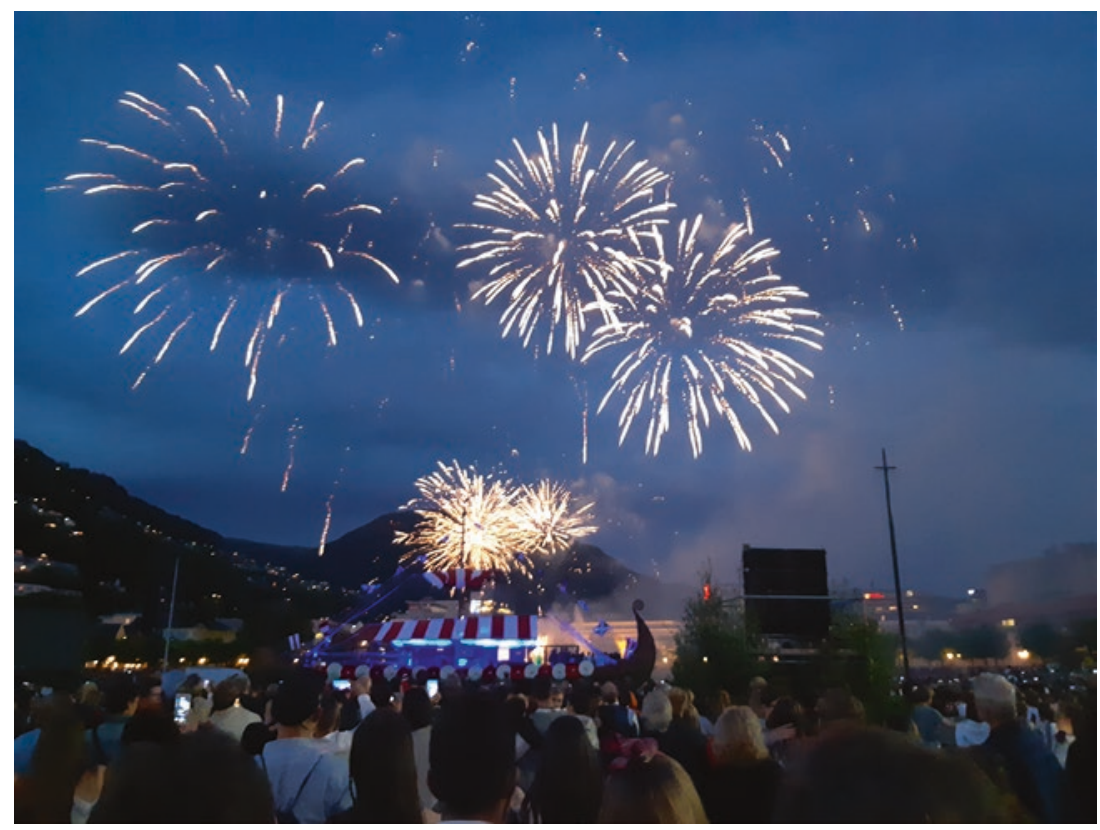

Fig. B1.20 The annual fireworks on 17 May in Bergen

The final section of the appendix ends this book with a poem that makes the case for hope amidst climate change catastrophe. The poem embodies an extension of the book's main line of argument. It gently but firmly states that, while enabling sustainable energy transitions is hard and prospects can at times look bleak, the stakes to ensure accountability are high, and we do have the tools and means at our disposal. 
The Case for Hope Amidst Climate Change Catastrophe

Is hope apocalyptic after all?

Does it let us wait, twiddling our thumbs, In between bursts

Of furious

Activity?

Do we find kindred spirits

In our search for salvation and think

We are closer

To accomplishment?

When in fact, loss follows loss,

Wildfires burn,

Countries drown,

Species disappear.

Or would that be an unkind misconstrual?

Do times like this

Render us in need

Of friends, now more than ever?

Is compassion our mast

Hope our guiding star

And empathy born of friendship

The wind in our gutsy sails?

Who loses? What prevails?

We fought for Initiative sixteen thirty-one The Pacific Northwest

The first frontier

Of hope for change to a politics of trying

Of recognising

What times call on us to do.

To make polluters pay, to compensate

Victims of fossil fuels and give a chance

To an energy sector powered by renewables 
In the here and now

Rather than

A decade hence.

But Big Oil poured in millions

Money talked and people listened

The Initiative took a beating.

Opportunities are fleeting

And it's already

Out of sight, out of mind,

All that we must leave behind.

No time to mope, the only way

To cope is to return to hope.

Or is it? Does hope motivate

Here in Seattle's sister city

Connected by a totem pole

Down at Nordnes in Bergen?

Or does remoteness obfuscate

While hope simply distracts,

Sustaining the unsustainable

Regurgitating facts

About one point five degrees

While delaying acts

That would keep it all in the ground,

Firmly under the sea

Out around Lofoten

Where our politics are floundering

Much like Pacific island states?

What scope is there for hope

When murder merely agitates

Blinded by greed? A world that's rigged

To keep expanding drilling.

Pumped by oil, we grease the wheels

And keep the coffers filling.

Softly we murmur "We are better

Than others at not spilling." 
The most majestic icebergs thaw

Glaciers are melting

New trade routes emerge

As opportunity.

That submerges hope.

It is a more powerful motivator.

What about the opportunity

To save hundreds of millions,

Entire coastal cultures from submergence?

When debate is anchored in opportunism

Hope is reduced to a spectacle.

We must defy and contest such

Imaginaries. Call them out

Consistently

As misleading hopemongers.

Hope is not Janus-faced, it does not look away

When counter-arguments are deposited.

Hope rests in respectful judgement,

In rooting for measured deliberation.

With no respect, no room for basic dignity,

No recognition of the right to life

In all its fullness

And diversity

It is apocalypse now.

Channel hope

To resist the dislocation

That perpetuates fossil fuel hegemony

And paves the way

For regulation to depoliticise

What is the most political thing of all:

Our future, our here and now,

The right to echo the call

Championed by Greta Thunberg. 
Hope is a tool to levy

Reasonable demands in unreasonable times

Expecting power to yield to truth.

We live in an apocalyptic moment

That empathy and friendship help us recognise.

Solidarity is our vessel of choice

And on these tumultuous waters under

Cloudy skies, hope is our guiding star. 


\section{INDEX}

A

Access, 4, 6, 18, 19, 21, 25, 27, 38, $48,55,56,80,81,98,99,106$, 112,133

Accountability analysis, 106, 109, 112, $113,115,129,141,152-155$

Accountability crisis, vii, 4-11, 110, 111,114

Automobility, 74, 75, 83-84, 86, 123, 132

B

Berlin, 36, 37, 42-50, 107-109, 120, $121,124,125,129,130,154$

Bureaucratic, 16, 19-22, 24, 54, 71, $96,106,108,111,113,114$, $118,120,123-128$

C

Colorado, 38, 90, 95, 99, 100, 114, $122,123,126-128,133$

Conflict, 37, 55, 65, 66, 107, 110, $121,123,125-127$
D

Discursive, 6, 16-19, 37, 66, 83, 106, $108,109,111,112,114,118$, $120,124-128$

E

Empirical, ix, 4, 16, 18, 25, 36, 38, $43,48-50,80,106,113,130$, $131,133,137,138$

Energy governance, 43, 45, 48, 129, 130

Energy infrastructure, 4, 5, 21, 27, 36, $38,42,48,49,107,108,120$, 121,125

Environmental governance, vi, viii, 8 , $16,28,36,39,47-48,80-83$, 91-94, 100, 107, 118, 119, 128-134, 138, 148

F

Financial, 9, 16, 20, 25-27, 49, 106, $108,110,111,113,114,118$, $120,124-128$

(C) The Author(s) 2020

S. Sareen (ed.), Enabling Sustainable Energy Transitions, https://doi.org/10.1007/978-3-030-26891-6 
H

Habitat exchange, 38, 90, 95, 99, $107,113,114,122,123$, $126-128,133$

Historical, 36, 37, 42, 43, 50, 107-109, 119-122, 124, 129, 137

\section{I}

Indonesia, 55-59, 107, 109

Institutional authority, 8-10, 18, 37, 121

M

Mobility transitions, 82, 120, 123, $124,127,128,132$

\section{$\mathbf{N}$}

Nordic, 38, 74-86, 107, 112, 113, $120,123,124,127,128,132$

Norway, v, 37, 69-71, 74, 79, 80, $111,113,122,125-127,158$, 159

O

Opportunistic/opportunism, 107, $110,120-122,125-126$

P

Performative/performativity, 37, 107, $111,120,126-127$

Portugal, 4-7, 16

Power-play, 107, 113, 120, 127-128
Practical, 9, 65, 90, 92, 96, 99, 106, 129,131

Practices of legitimation, vii-ix, 7-11, 16-28, 36, 39, 42, 43, 48-50, 91, 95, 106-115, 118, 123-129, $137,138,153$

Prefigurative/prefiguration, 107, 111, $112,120,126,127$

$\mathbf{R}$

Routinisation, 107, 120, 123, 128

$S$

Sage-grouse, 38, 90, 91, 93, 99-100, $113-115,122,123,126,127$, 133

Spatial/spatiality, 25, 27, 42, 47, 107, $112,120,121,124,129$

Sustainability transition, 67-68, 91, 92,97

T

Target-setting, 37, 64-71, 107, $111,121,122,125,126$, 155

Technocratic, 16, 22-25, 106, 108, $110,111,113,114,118,120$, 124-128

Temporal/temporality, 24, 50, 107, $108,120,124-125,129$

\footnotetext{
Z

Zero Growth Objective, 68-71, 111, $121,122,126$
} 